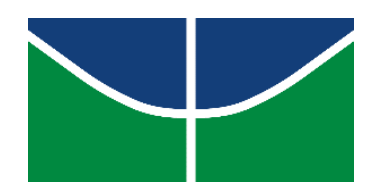

UNIVERSIDADE DE BRASÍLIA - UNB

FACULDADE DE EDUCAÇÃO - FE

PROGRAMA DE PÓS-GRADUAÇÃO EM EDUCAÇÃO MODALIDADE

PROFISSIONAL - PPGE-MP

KLEVER CORRENTE SILVA

EDUCAÇÃO PARA A CARREIRA E PROJETO DE VIDA: confluência das Representações Sociais e do Habitus estudantil

Orientadora: Profa. Dra. Olgamir Francisco de Carvalho

BRASÍLIA - DF 


\section{KLEVER CORRENTE SILVA}

\section{EDUCAÇÃO PARA A CARREIRA E PROJETO DE VIDA: confluência das \\ Representações Sociais e do Habitus Estudantil}

Dissertação apresentada ao Programa de PósGraduação em Educação - modalidade profissional, da Faculdade de Educação da Universidade de Brasília, como requisito parcial para obtenção do título de Mestre em Educação, área de concentração: Políticas e Gestão da Educação Básica, sob a orientação da Profa. Dra. Olgamir Francisco de Carvalho.

Aprovado em 15/07/2019

Banca Examinadora:

Profa. Dra. Olgamir Francisco de Carvalho - Orientadora PPGE-MP/FE/UnB

Prof. Dr. Bernardo Kipnis - Membro interno

PPGE-MP/FE/UnB

Prof. Dr. Moisés Domingos Sobrinho - Membro externo

PPGEd/CE/UFRN

Profa. Dra. Urânia Flores da Cruz Freitas - Suplente

SEEDF

BRASÍLIA - DF 
Ficha catalográfica elaborada automaticamente, com os dados fornecidos pelo(a) autor(a)

Silva, Klever Corrente

Educação para a Carreira e Projeto de Vida: confluência das Representações Sociais e do Habitus estudantil / Klever Corrente Silva; orientador Olgamir Francisco de Carvalho. - Brasilia, 2019. $112 \mathrm{p}$.

Dissertação (Mestrado - Mestrado Profissional em Educação -- Universidade de Brasilia, 2019.

1. Orientação Vocacional e Profissional. 2. Educação para a Carreira. 3. Representaçōes sociais. 4. Habitus. 5.

Projeto de Vida. I. Carvalho, Olgamir Francisco de, orient. II. Título. 
Dedico este trabalho aos meus avós, que merecem a homenagem pelas conquistas e vitórias em meu Projeto de Vida, pois estas só foram possíveis graças à sólida base por eles fornecida. 


\section{AGRADECIMENTOS}

Desenvolver uma Dissertação de Mestrado é uma tarefa árdua, e para o sucesso da minha empreitada tive o apoio de muitas pessoas que direta ou indiretamente contribuíram para a concretização deste. Por isso, gostaria de realizar os meus agradecimentos:

À Deus, pelas oportunidades que tive e que possibilitaram que eu chegasse onde estou.

Aos meus pais, por me darem o direito de nascer e por todo apoio.

Aos meus avós, por terem sido meus primeiros educadores, por sempre estarem comigo e por me darem toda a base necessária para eu ser quem sou.

Ao meu marido, Anderson Peixoto, pelo companheirismo e paciência.

À minha orientadora, Olgamir Carvalho, pelo acolhimento, pela relação autêntica de orientação, por todos os direcionamentos e por viabilizar que eu me cativasse ainda mais pelo campo da Orientação Vocacional e Profissional.

Aos professores Bernardo Kipnis, Moisés Domingos Sobrinho e Urânia Freitas, por aceitarem o convite de comporem a banca examinadora deste trabalho e pelas contribuições para o aprimoramento deste trabalho.

Aos professores que já participaram e aos que ainda participam da minha trajetória de vida, por contribuírem com o meu processo formativo e me preparem para a vida. Minha eterna gratidão pela escolha vocacional de cada um desses profissionais e por se empenharem na formação dos sujeitos para uma sociedade melhor.

Aos meus colegas pós-graduandos, por terem sido parceiros nessa trajetória através da escuta, do debate, da sugestão e do incentivo.

À Secretaria de Estado de Educação do Distrito Federal (de modo especial, aos servidores Luciana Brito, Lúcia Andrade e Alexandre Carvalho que prestigiaram defesa deste trabalho), à escola que essa investigação foi realizada e, em destaque, à orientadora educacional Fabiana Mendes pelo suporte e viabilização do tempo e espaço para a realização da pesquisa empírica.

À toda equipe da Escola Classe 33 de Ceilândia, local que trabalho, pela compreensão e auxílio para que eu conseguisse conciliar os estudos e o trabalho.

Aos meus ex-alunos e alunos, por serem a minha motivação de ser um professor e pesquisador melhor.

Aos meus familiares (em especial à minha irmã, Tatiane Corrente, por sempre estar presente e me apoiar), amigos e colegas pelo apoio e pela torcida. 
"Nenhum vento sopra a favor de quem não sabe para onde ir." Sêneca 


\title{
EDUCAÇÃO PARA A CARREIRA E PROJETO DE VIDA: CONFLUÊNCIA DAS REPRESENTAÇÕES SOCIAIS E DO HABITUS ESTUDANTIL
}

\begin{abstract}
RESUMO
Esta pesquisa tem como objeto de estudo a Educação para a Carreira, uma modalidade de Orientação Vocacional e Profissional (OVP) voltada para o contexto educacional. Atualmente, as escolas do Distrito Federal não possuem serviços institucionalizados e universalizados que preparem os estudantes para realizarem escolhas e tomarem decisões em relação aos seus projetos de vida, e sem esse suporte, eles enfrentam essa problemática sozinhos, com dificuldades, não conseguindo avaliar adequadamente as suas consequências. Diante desse cenário, esta investigação busca, por um lado, identificar as problemáticas vocacionais que os jovens do ensino médio enfrentam nesta fase da vida e, por outro lado, busca analisar também, o papel da Educação para a Carreira na preparação para as escolhas e tomadas de decisões. Para tanto, foi realizada uma pesquisa empírica com estudantes concluintes do ensino médio da rede pública de ensino do Distrito Federal. Embasada em um modelo teórico que articula a Teoria das Representações Sociais de Moscovici e a Praxiologia Social de Bourdieu, aplicou-se um questionário para apreender os referentes do habitus estudantil e um teste de associação livre de palavras para conhecer as representações elaboradas e partilhadas coletivamente pelo grupo estudado. Os resultados apontam que o habitus estudantil confluem e dialogam com as representações sociais. Identificou-se os estudantes vivenciaram poucas ou nenhuma atividade na escola que os preparassem para o processo de escolhas e tomadas de decisões. Percebeu-se que os alunos reconhecem a função orientadora e preparatória da escola e sentem a necessidade de a escola auxiliar no processo de OVP sistematicamente. Ademais, constatou-se que os discentes encaram o processo de escolha de uma carreira ou profissão como importante, difícil e estressante. Apresenta-se nesta pesquisa, também, um relatório técnico que mapeia as iniciativas de Projeto de Vida nos estados brasileiros e, como contraponto, indica-se a Educação para a Carreira, enquanto abordagem que responde adequadamente às lacunas identificadas nos processos formativos, às demandas solicitadas pelo Estado e pela sociedade e aos anseios e expectativas dos estudantes. Constatou-se, que através da Educação para a Carreira é possível ampliar e transformar o entendimento e a percepção dos discentes preparando-os para o seu processo de escolha e tomada de decisões em seu Projeto de Vida.
\end{abstract}

Palavras-chave: Orientação Vocacional e Profissional. Educação para a Carreira. Representações sociais. Habitus. Projeto de Vida. 


\title{
CAREER EDUCATION AND LIFE PROJECT: CONVERGENCE OF SOCIAL REPRESENTATIONS AND STUDENT HABITUS
}

\begin{abstract}
This research has Career Education as its object of study, a modality of Professional and Vocational Guidance aimed at the educational context. Nowadays, schools in the Federal District do not offer institutionalized and universal services that prepare students to make choices and decisions related to their life projects, and without such a support system, they face these problems alone, with difficulty, unable to properly assess the consequences of their choices. Contemplating this issue, this study seeks to, on the one hand, identify vocational problems that young students in high school face, and on the other hand, it also seeks to analyze the role of Career Education in the preparation for choice and decision-making. To this purpose, an empirical research was conducted with students that are finishing high school in public schools in the Federal District. Based on a theoretical model which articulates Moscovici's Social Representation Theory with Bourdieu's Social Praxeology, a questionnaire was handed out to collect references on students' habitus, and a word association test was applied to better comprehend the representations that are elaborated and shared by the studied group. Results show that the students' habitus converge with social representations. Students that have few or no activities in school that prepare them for the choice and decision-making process were identified. It was perceived that students recognize the orientation and preparatory activities in school and feel the need of having the school's systematical support in the Professional and Vocational Guidance process. Moreover, we have found that they view the process of choosing a career or profession as an important one, as well as being difficult and stressful. This research also presents a technical report which maps out the initiatives of life projects in Brazilian states, and as a counterpoint, we indicate Career Education, since it is an approach that adequately fills gaps that are identified in the educational process, in addition to fulfilling demands made by the Government and by society, along with the students' yearnings and expectations. We have found that through Career Education, it is possible to broaden and transform the understanding and perception of students, preparing them to make choices and decisions related to their life projects.
\end{abstract}

Keywords: Professional and Vocational Guidance. Career Education. Social Representation. Habitus. Life Project. 


\section{LISTA DE ABREVIATURAS E SIGLAS}

BNCC - Base Nacional Comum Curricular

CODEPLAN - Companhia de Planejamento do Distrito Federal

CONSED - Conselho Nacional de Secretários de Educação

EMTI - Ensino Médio em Tempo Integral

ENEM - Exame Nacional do Ensino Médio

IA - Instituto Aliança

IAS - Instituto Ayrton Senna

ICE - Instituto de Corresponsabilidade pela Educação

INEP - Instituto Nacional de Estudos e Pesquisas Educacionais Anísio Teixeira

MEC - Ministério da Educação

OCDE - Organização de Cooperação para o Desenvolvimento Econômico

OVP - Orientação Vocacional e Profissional

SEEDF - Secretaria de Estado de Educação do Distrito Federal

TALP - Teste de Associação Livre de Palavras

TCLE - Termo de Consentimento Livre e Esclarecido

TRS - Teoria das Representações Sociais 


\section{LISTA DE QUADROS}

Quadro 1 - Educação para a Carreira nos currículos escolares ............................................22

Quadro 2-Quadrantes da estrutura das representações sociais

Quadro 3 - Estrutura da representação social construída pelos estudantes sobre a função da escola

Quadro 4 - Estrutura da representação social construída pelos estudantes sobre a escola ......51

Quadro 5 - Estrutura da representação social construída pelos estudantes sobre a relação da

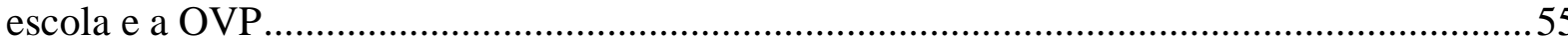

Quadro 6 - Estrutura da representação social construída pelos estudantes sobre o processo de

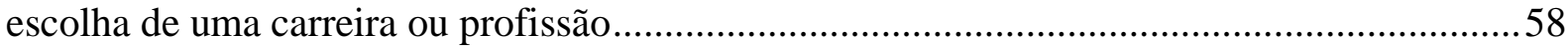

Quadro 7 - Progressão curricular da subdimensão "Autoeficácia" da competência "Trabalho e

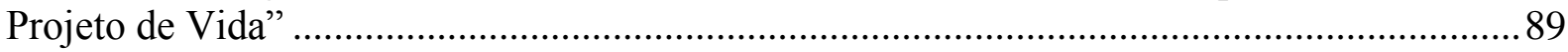




\section{SUMÁRIO}

INTRODUÇÃO

1 A MULTIDETERMINAÇÃO DA RELAÇÃO EDUCAÇÃO E TRABALHO E A QUESTÃO DA OVP NA SOCIEDADE CONTEMPORÂNEA.

1.1 Pressupostos Básicos da Educação para a Carreira ...................................................20

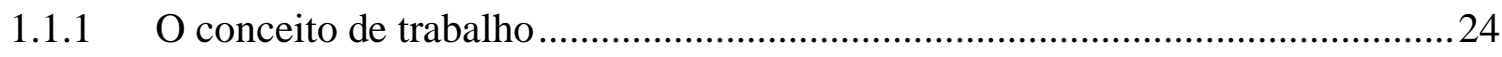

1.1.2 O processo de ensino-aprendizagem e o desenvolvimento vocacional ..............26

1.1.3 O desenvolvimento de hábitos e atitudes relativos ao trabalho .........................29

1.1.4 A colaboração entre a escola e a comunidade ocupacional ................................30

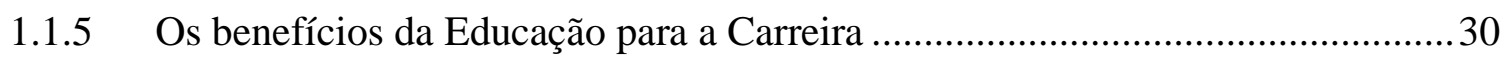

1.2 A Teoria das Representações Sociais (TRS) e a Praxiologia de Bourdieu .................32

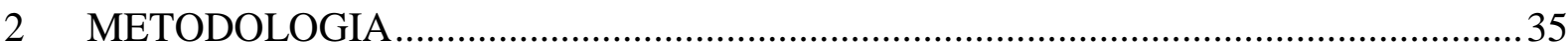

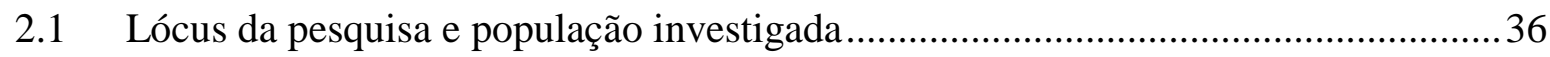

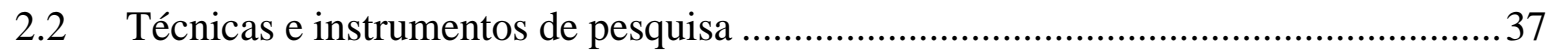

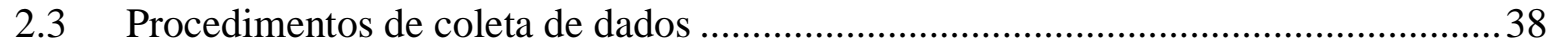

2.4 Análise/Interpretação dos resultados .............................................................40

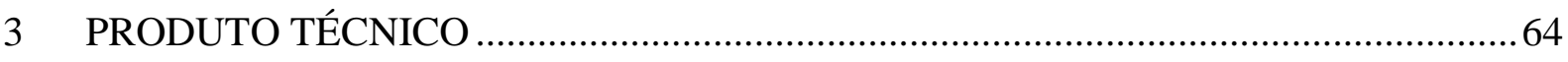

3.1 Características das iniciativas de projeto de vida nas secretarias de estado de educação 66

3.2 Diretrizes e orientações pedagógicas para o trabalho com projeto de vida em âmbito federal...... .84

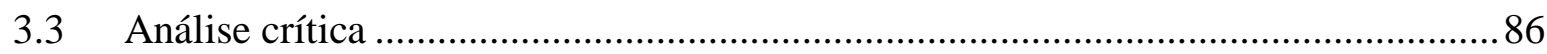

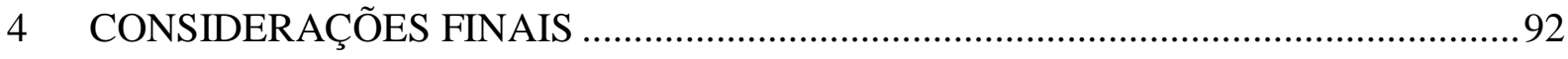

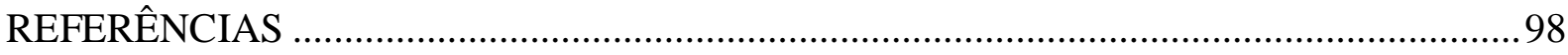

APÊNDICE A - TERMO DE CONSENTIMENTO LIVRE E ESCLARECIDO E TESTE DE

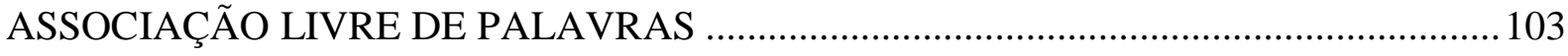

APÊNDICE B - QUESTIONÁRIO SOCIOECONÔMICO E CULTURAL .......................... 105 


\section{INTRODUÇÃO}

Esta pesquisa tem como objeto de estudo a Educação para a Carreira, uma modalidade de OVP voltada para o contexto educacional, focalizando-se especificamente a educação básica sob a ótica de estudantes do ensino médio. O presente trabalho se junta assim, ao conjunto de pesquisas que valorizam o ambiente educacional como local adequado para o desenvolvimento vocacional e profissional dos estudantes e para a discussão de temas relativos à relação educação e trabalho.

Tendo em vista a contextualização da problemática vocacional e a sua relação com a educação na sociedade contemporânea, deve-se levar em consideração que esta questão não pode ser compreendida sem referência à estrutura social que a engendra.

O mundo do trabalho vivencia uma metamorfose que altera os padrões de comportamento dos indivíduos e de toda a sociedade. Hoje, crianças, adolescentes e jovens, se deparam com um mundo altamente tecnológico, que possibilita a conexão e o plugar-se em alguma atividade em questão de segundos. Seja assistir um programa de televisão, ouvir uma música, visualizar ou fazer uma story ou status para alguma rede social, as opções são muitas e elas são trocadas em um touch. Um simples toque de tela, revela as escolhas e as preferências diante de um acervo informacional tão abundante (LEVENFUS, 2002).

A trajetória dos estudantes da educação básica é marcada por uma série de transições: do ambiente familiar para a educação infantil, da educação infantil para os anos iniciais do ensino fundamental, dos anos iniciais para os anos finais, do ensino fundamental para o ensino médio, do ensino médio para o ensino superior e/ou a transição para o mercado de trabalho. A problemática das transições acentua-se na adolescência, fase de muitas rupturas e crises constantes, dentre elas as perdas inerentes a esta fase da vida: pelo corpo infantil, pelas formas infantis de relação, pela onipotência infantil (BOHOSLAVSKY, 2015), entretanto, é justamente na adolescência que cada vez mais se requer que os jovens tomem decisões importantes, como por exemplo: se irão fazer um curso técnico, se irão ingressar na universidade, qual ocupação ou profissão assumirão para a vida e o que precisa ser feito para concretizar os seus projetos.

Embora essas questões sejam fundamentais e exijam a capacidade de fazer escolhas e tomar decisões, o fato é que inexistem no Distrito Federal serviços que preparem os estudantes para realizá-las adequadamente.

Trazendo alguns elementos da minha vivência, como estudante e professor de educação básica e profissional da rede pública de ensino do Distrito Federal, pude testemunhar a 
pertinência e relevância de um serviço de Orientação Vocacional e Profissional (OVP) na educação básica, bem como das consequências de sua inexistência institucional. Várias escolas realizam palestras, feiras de profissões ou eventos pontuais relacionados à OVP, porém a inexistência de um processo institucionalizado ou um serviço sistematizado não possibilita aos alunos se desenvolverem vocacionalmente, isto é, não aprendem a refletirem sobre os seus projetos de vida, suas escolhas e decisões.

É oportuno destacar que, no ano de 2016, a Presidência da República instituiu a Medida Provisória $\mathrm{n}^{\mathrm{o}} 746$, convertida posteriormente na Lei Federal $\mathrm{n}^{\circ} 13.415$, de 16 de fevereiro de 2017, que trouxe alterações para as diretrizes e bases da educação nacional. Entre as alterações ocorridas, e que se relaciona diretamente com essa investigação, encontra-se a mudança na estrutura do Ensino Médio e a inclusão de trabalho voltado para a construção de Projeto de Vida dos estudantes nos currículos desta etapa da Educação Básica. Diante dessa demanda, as Secretarias Estaduais de Educação iniciaram um processo de reforma curricular, buscando incluir a temática Projeto de Vida nos processos de formação dos estudantes.

Nesse sentido, esta dissertação também se insere nesse contexto de reconfiguração do ensino médio, buscando compreender como a Educação para a Carreira pode dar um suporte ao aluno na perspectiva de integrar o seu desenvolvimento acadêmico e vocacional.

Convém afirmar que, sem esse suporte, os jovens enfrentam a problemática vocacional como as demais atividades, nas quais se conecta e desconecta com facilidade, não considerando que o processo de escolha é um ato complexo e eivado de consequências.

Uma demonstração das consequências de uma escolha inadequada pode ser constatada na trajetória estudantil universitária. O Instituto Nacional de Estudos e Pesquisas Educacionais Anísio Teixeira (INEP, 2018) realizou um levantamento referente a trajetória desses estudantes, com base no censo da educação superior entre os anos 2010 e 2015, e constatou que dos 2.502.933 alunos matriculados em cursos superiores de todo o país em instituições públicas e privadas, $55,6 \%$ não se formaram no curso que se matricularam inicialmente. Dentre as justificativas para esse alto índice estão as escolhas inadequadas realizadas pelos alunos, por não se identificarem com o curso, pela complexidade dos estudos ou por não vislumbrarem perspectivas dentro da área.

Vive-se em um sistema que exige decisões assertivas, mas não proporciona uma educação que possibilite a construção de escolhas realistas e conscientes no que tange à profissão/ocupação (CARVALHO, 2014). Entende-se que as evasões e trocas de curso decorrentes da não-identificação e adaptação com o curso e carreira, conforme mencionados anteriormente, estão relacionadas com a construção de representações que foram atribuídas a 
essas escolhas, que por sua vez, estão relacionados à cultura, à trajetória e às razões de ordem econômica, social e simbólica desses estudantes.

Nesse sentido, é pertinente estudar as representações que esses jovens constroem sobre a escola, a sua função, a sua relação com a OVP e a escolha de uma carreira ou profissão. E para além de apenas apreender esses significados, faz-se oportuna a identificação também dos aspectos que estão na base dessas construções visando propor uma mudança desta realidade. Pressupõe-se que isso é possível a partir da abordagem de OVP chamada de Educação para a Carreira, pois ela responde adequadamente às demandas das transformações da sociedade e do mundo do trabalho.

Perrenoud (2013) afirma que diante da transformação do mundo do trabalho, em grande parte por conta da substituição do capitalismo industrial pelo capitalismo financeiro, a escolaridade obrigatória não ensina ninguém a compreender as transformações do trabalho e do mundo do trabalho. O autor também afirma que a escola não é a instituição responsável pelo funcionamento do universo do trabalho, porém ela deve refletir para entender por quê as pessoas estão tão pouco preparadas para vivenciar as transformações.

Greenhaus e Callanan (2006) nos ajudam a distinguir o significado socioeconômico de mercado de trabalho e mundo do trabalho, expressões que parecem sinônimas, mas na verdade carregam sentidos distintos. Para eles, mercado de trabalho é o conjunto de atividades ocupacionais e profissionais em dada sociedade em dada época, calcadas sobre as relações de oferta de trabalho (por parte dos empregadores) e procura de trabalho (por parte dos demandantes de trabalho ou trabalhadores). O mercado de trabalho é, portanto, todas as possibilidades de trabalho que são ofertadas pelo mercado formal e constitui-se como uma parte integrante do mundo do trabalho.

Já mundo do trabalho é o conjunto de determinantes e processos sociais que definem, articulam e regulam tanto as atividades ocupacionais e profissionais, quanto toda e qualquer forma de trabalho (formal e informal, produtivo, improdutivo ou reprodutivo) em dada sociedade em determinada época, dando-lhes forma, significado e legitimação social. É constituído por todas as possibilidades de trabalho oferecidas pelo mercado formal e informal, sendo o mercado de trabalho parte integrante do mundo do trabalho (GREENHAUS; CALLANAN, 2006).

A escola, portanto, presta um serviço mais amplo para a sociedade ao atendê-la formando as pessoas para a vida cidadã e para o trabalho em sua acepção mais ampla. Embora as pessoas, de um modo geral, queiram assumir postos no mercado de trabalho e construírem uma carreira, existem outras possibilidades que podem ser consideradas e existem aspectos 
sobre a oferta e demanda de postos de trabalho que precisam ser desvelados pelas instituições educacionais.

Entretanto, no contexto atual, os jovens não são preparados para compreender o mundo do trabalho e tampouco tomar decisões sobre ele. Há uma preocupação pela inserção dos jovens no ensino superior, em especial, por aprovações nas universidades públicas e o ensino médio, última etapa da educação básica, muitas vezes é reduzido a uma preparação para o vestibular, como se esta fosse a única alternativa e como se houvesse vagas para todos. Em contraste a esse cenário, prepara-se para o vestibular, mas não se prepara para fazer a escolha do curso, e se o fazem, são poucas as iniciativas e de forma muito incipiente. A necessidade de tomar decisões vocacionais e profissionais ocorre de forma pontual, sob as pressões dos pais, da dúvida sobre qual caminho seguir, da alta seletividade do vestibular, de sentir sua competência sendo colocada à prova, além da opção de inserção no mercado de trabalho seja para ajudar no sustento familiar ou por outras razões.

O imediatismo e a superficialidade da decisão do que fazer após o final do ensino médio é um imbróglio, podendo causar sofrimento, desgaste e frustração, pois essa tomada de decisão na maioria das vezes não foi construída e consolidada ao longo de sua trajetória escolar (CARVALHO, 2014).

Atualmente com o advento das novas tecnologias, os sujeitos das escolhas, majoritariamente estão conectados e tem muitas possibilidades de acesso à informação, em contrapartida não tem maturidade para selecioná-las criticamente (LEVENFUS, 2002). A escola como instituição formadora dos cidadãos, pode auxiliar nesse processo realizando atividades que desenvolvam o amadurecimento para as escolhas e para a construção dos projetos de vida dos seus educandos.

Considerando que a educação precisa estar vinculada ao mundo do trabalho e que ela é um processo formativo que tem por finalidade preparar o indivíduo integralmente para a cidadania e para o trabalho, esta pesquisa situa-se na interseção entre a educação e o mundo do trabalho.

A terminologia Orientação Vocacional e Profissional, utilizada nesta dissertação, aglutina o conceito de orientação profissional, que se trata de "trabalhos que informam e orientam a respeito das profissões, de mercado de trabalho, aplicando técnicas de aprendizagem" (LEVENFUS, 2002, p. 58), com o conceito de orientação vocacional ocupacional, que é a "busca de conhecimento a respeito de si mesmo, de características pessoais, familiares e sociais do orientando, promovendo o encontro das afinidades do mesmo com aquilo que pode vir a realizar em forma de trabalho" (LEVENFUS, 2002, p. 58). Assim, a 
perspectiva aqui adotada, não trata do direcionamento de ocupações que mais se adequem aos jovens de acordo com os seus interesses ou aptidões, mas de atividades informativas e orientadoras a respeito do mundo do trabalho, das profissões, dos processos de escolha, da aprendizagem ao longo da vida e do autoconhecimento, utilizando-se da aplicação de técnicas de ensino-aprendizagem.

A OVP é um processo transdisciplinar para o qual diferentes campos se confluem, como a pedagogia, a psicologia, a administração e outros. Dentre as múltiplas abordagens existentes nesses diversos campos, optou-se pela modalidade da Educação para a Carreira por acreditar que seja a mais adequada para o contexto educacional, pelo fato do currículo ser o mecanismo para a integração dos processos de ensino-aprendizagem e de desenvolvimento vocacional e profissional.

A Educação para a Carreira consiste no esforço integral, da educação pública e da sociedade, direcionado a ajudar os indivíduos a se familiarizarem com os valores de uma sociedade orientada para o trabalho, a integrar estes valores em seus sistemas de valores pessoais e implementar esses valores em suas vidas a fim de que o trabalho seja possível, significativo e satisfatório para cada indivíduo (HOYT, 2005).

A Educação para a Carreira é uma modalidade de OVP realizada no âmbito escolar, construída para ser desenvolvida por professores, portanto, o fundamento das suas ações não está em métodos psicométricos, mas em atividades pedagógicas pertinentes à atuação do docente e tendo como eixo central a categoria trabalho (CARVALHO, 2014). Alternativas de futuro, dialogadas e mediadas por um professor, podem ser possíveis, a partir de oportunidades pedagógicas específicas. Por isso, acredita-se que esta modalidade pode abrir possibilidades que talvez não ocorressem sem tais mediações.

Ao buscar um referencial teórico-metodológico que fundamentasse a epistemologia desta investigação, verificou-se a necessidade de escolher um quadro de referências que viabilizasse a análise articulando a abordagem crítico-dialética e o modelo teórico das Representações Sociais-Praxiologia. Considerando essa combinação de perspectivas, com o intuito de alcançar a totalidade do fenômeno investigado, adota-se neste estudo:

- Como metateoria, a abordagem crítico-dialética, para questionar a OVP na multideterminação da relação entre educação e trabalho tendo como fundamento um interesse investigativo crítico-emancipador que desvenda as contradições e as potencialidades de transformação social (GAMBOA, 2008);

- E, o modelo teórico desenvolvido por Domingos Sobrinho (2014) que articula a Teoria das Representações Sociais (TRS) de Serge Moscovici e a Praxiologia de 
Bordieu. Por meio dele aponta-se como o habitus estudantil gesta a construção da representação social de aspectos relativos a escola, a sua função, a sua relação com a OVP e a escolha de uma carreira ou profissão, servindo de guia para as suas ações no contexto escolar e em relação à carreira.

Nessa conjunção teórico-metodológica é possível evidenciar a articulação entre os aspectos macro e microssociais e como estes influem nas trajetórias dos agentes construtores das representações sociais sobre as temáticas vocacionais, servindo de guia para as suas ações. Assim, evidencia-se uma articulação entre as questões de ordem material e simbólica dos sujeitos tomada em uma perspectiva dialética e descobre-se indícios para possíveis intervenções visando a transformação da realidade.

Considerando essas reflexões esta investigação parte dos seguintes questionamentos: quais são as representações sociais dos jovens sobre a escola, a sua função, a sua relação com a OVP e a escolha de uma carreira ou profissão? Como a Educação para a Carreira na educação básica pode ampliar e transformar o entendimento e a percepção dos estudantes preparando-os sobre o seu processo de escolha e tomada de decisões em seu Projeto de Vida?

Tendo em vista as questões formuladas, esta pesquisa estabelece os seguintes objetivos:

Objetivo Geral:

Analisar o papel da Educação para a Carreira na ampliação das representações sociais dos estudantes de ensino médio e na preparação para a realização de escolhas e tomada de decisões em seu Projeto de Vida.

Como objetivos específicos este estudo propõe:

- Identificar o conteúdo e a estrutura das representações sociais dos estudantes sobre a escola, a sua função, a sua relação com a OVP e a escolha de uma carreira ou profissão;

- Correlacionar as representações sociais identificadas com os pressupostos básicos da Educação para a Carreira;

- Produzir um Relatório Técnico Conclusivo apresentando o conteúdo das iniciativas de Projeto de Vida das Secretarias de Estado de Educação e contrastá-las com os fundamentos da Educação para a Carreira.

Esta dissertação está estruturada em 3 capítulos: no primeiro capítulo põe-se em questão a OVP na multideterminação da relação entre educação e trabalho abordando-se os pressupostos básicos da Educação para a Carreira e discutindo-se a construção das representações sociais e sua relação dialética com o habitus e outros elementos da praxiologia de Bourdieu. O segundo capítulo apresenta os procedimentos metodológicos utilizados pela pesquisa empírica. No 
terceiro capítulo, apresenta-se um produto técnico, que se constitui em um Relatório Técnico Conclusivo sobre as iniciativas de Projeto de Vida das Secretarias de Estado de Educação cotejando-as com os fundamentos da Educação para a Carreira. 


\section{A MULTIDETERMINAÇÃO DA RELAÇÃO EDUCAÇÃO E TRABALHO E A QUESTÃO DA OVP NA SOCIEDADE CONTEMPORÂNNEA}

A escola é uma instituição oficial que contribui para o processo de desenvolvimento do estudante, que o prepara para a vida cidadã, para o trabalho e para o prosseguimento nos estudos, portanto, ela é a instituição que precisa responder às necessidades do mundo contemporâneo, orientando os educandos a enfrentarem os desafios do mundo do trabalho.

Carnoy e Levin (1987, p. 97) afirmam que "os jovens são preparados para os papéis adultos, bem antes de chegar ao local de trabalho" e a partir da análise das práticas escolares, evidenciam o papel contraditório da escola, como reprodutora das relações sociais e, ao mesmo tempo, como espaço de mudança social.

\footnotetext{
A educação pública é tanto um subsídio aos empregadores, quanto um modo dos trabalhadores obterem mobilidade social; treina os jovens para serem bons trabalhadores e bons democratas, reproduzindo uma força de trabalho estruturada por classes, que se ajuste a uma divisão do trabalho historicamente definida, mas também inculcando aspirações relativas à natureza do trabalho numa função democrática (CARNOY; LEVIN, 1987, p. 98).
}

A OVP é um serviço que ajuda os indivíduos a lidarem com a dualidade sobrevivência/desejo (CARVALHO, 2014). Anteriormente os empregos eram estáveis, com possibilidades de promoção ao longo da sua trajetória profissional, que era bem clara e definida. Já na sociedade atual, globalizada, há a incerteza quanto ao futuro das ocupações e o acirramento da competição que acarreta a flexibilização e precarização do trabalho na qual muitos se subjugam para sobreviverem. Levenfus $(2002$, p. 58) afirma que "o homem trabalha para viver, mas, ao mesmo tempo, pode obter prazer das atividades produtivas. Independente do grau de riqueza e educação, o trabalho ocupa grande parte do tempo de vigília do ser humano".

O serviço de OVP é capaz de ajudar os indivíduos a analisarem os determinantes econômicos, políticos, sociais, educacionais, culturais de suas escolhas e decisões e desse contexto socioeconômico-cultural examinarem a sua situação, construírem o seu projeto de vida, sem esquecer que existe uma distância entre o estímulo à escolha as possibilidades de concretização, portanto, agrega-se na atividade de OVP o autoconhecimento e o conhecimento da realidade (CARVALHO, 2014).

O que ocorre é que "a falta de obrigatoriedade curricular joga o jovem completamente sozinho diante de um dilema que decidirá seu futuro" (LEVENFUS, 2002, p. 52). O sujeito precisa orientar-se sozinho, o que muitas vezes gera confusão. 
Existem alguns aspectos que acentuam a desorientação e a dificuldade em realizar as escolhas: o desconhecimento de si próprio; o desconhecimento das profissões que existem (o que se exige e também as informações sobre o mercado de trabalho); a incapacidade de obter informações ou de utilizar as disponíveis; a dificuldade para decidir-se entre profissões que demonstram-se igualmente atraentes; a dificuldade para identificar profissões percebidas como adequadas a si, às expectativas da família ou de outras pessoas ou grupos importantes para o indivíduo; a dificuldade para conciliar os diferentes fatores que afetam a escolha (FERRETTI, 1992).

Dessa forma, após introduzir a questão da OVP na sociedade contemporânea e contextualizar brevemente a multideterminação da relação entre educação e trabalho, abordase a seguir os pressupostos básicos da Educação para a Carreira, um serviço educacional que tem a potencialidade de responder aos elementos tratados anteriormente.

\subsection{PRESSUPOSTOS BÁSICOS DA EDUCAÇÃO PARA A CARREIRA}

A Educação para a Carreira é uma modalidade de orientação de carreira, a ser desenvolvida de forma sistemática no contexto escolar contribuindo para que os estudantes adquiram competências-chave para o desenvolvimento da carreira e democratizando o acesso à OVP, atualmente restrita a poucos (MUNHOZ; MELO-SILVA, 2011). A nomenclatura Educação para a Carreira, portanto, é empregada para designar o procedimento de OVP realizado dentro do contexto educativo.

O movimento da Educação para a Carreira surgiu na década de 1970 com Sydney P. Marland Jr., comissário do Departamento de Educação nos Estados Unidos, diante de um cenário que reivindicava reformas educacionais que vinha se desenhando. Os principais aspectos de preocupação eram: o distanciamento existente entre a educação e a vida profissional; a dificuldade dos jovens terem uma experiência no mundo do trabalho face à complexidade das novas ocupações; o analfabetismo ocupacional; a incapacidade do sistema produtivo de absorver os egressos do sistema educacional, que consequentemente ficavam desempregados ou tinham poucas chances de exercerem uma profissão de acordo com os estudos desenvolvidos e; a mudança na estrutura do mercado de trabalho no que se refere à estabilidade dos postos de trabalho, exigindo o desenvolvimento contínuo da empregabilidade por parte dos indivíduos para mudarem de emprego ou postos de trabalho (RODRÍGUEZ; CARMONA, 1995). 
Segundo Rodríguez e Carmona (1995), Marland almejava que a preparação acadêmica se equilibrasse com o desenvolvimento vocacional e profissional, harmonizando os currículos a essas demandas da sociedade. No seu entendimento era necessário que se estabelecesse um vínculo significativo entre a educação e o trabalho, havendo uma reforma educacional no qual o trabalho fosse um elemento significativo.

Hoyt (1975), um dos principais impulsionadores da teoria em questão, elenca alguns aspectos que demandavam respostas do sistema educativo, propiciando o desenvolvimento da Educação para a Carreira:

- Muitas pessoas deixam o sistema educativo carecendo de habilidades acadêmicas básicas necessárias para adaptar-se a uma sociedade atual que muda rapidamente;

- Muitos estudantes não conseguem relacionar o que aprendem na escola e o que terão que fazer quando deixarem o sistema educativo;

- A organização da educação atende melhor as necessidades da minoria dos estudantes que chegariam a serem universitários, enfatizando o nível superior e deixando em segundo plano os projetos de vida daqueles que nunca serão universitários;

- A educação não considera as rápidas mudanças da sociedade pós-industrial, havendo um descompasso entre as qualificações dos trabalhadores e os requisitos do trabalho;

- Muitas pessoas abandonam o sistema educacional, tanto básico quanto superior, sem terem desenvolvido competências vocacionais que são essenciais para a adequada transição escola-trabalho;

- A crescente necessidade da presença da mulher no mundo do trabalho não tem refletido adequadamente nas opções educativas, nem nas vocacionais;

- O sistema de educação pública não atende a crescente necessidade de uma educação contínua e recorrente aos adultos;

- O não-aproveitamento das oportunidades de aprendizagem fora da estrutura formal da educação e que são importantes para a sociedade;

- Não se tem estabelecido um papel adequado, na formulação da política educativa, a sociedade de uma forma geral, incluindo os pais e a comunidade ocupacional;

- A educação, tal como está estruturada, não satisfaz adequadamente as necessidades das minorias ou das pessoas de camadas populares na sociedade;

Diante desse contexto, os teóricos desenvolveram a Educação para a Carreira, que é

o esforço total da educação pública e da mais ampla comunidade direcionado a ajudar a todos os indivíduos a se familiarizarem com os valores de uma sociedade orientada para o trabalho, a integrar estes valores em seus sistemas de valores pessoais e 
implementar estes valores em suas vidas de forma que o trabalho chegue a ser possível, significativo e satisfatório para cada indivíduo (HOYT, 2005, p. 16).

Essa modalidade e seus pressupostos vem sendo adotados por diversos países, sob diferentes formas dependendo do objetivo estabelecido.

A Organização de Cooperação para o Desenvolvimento Econômico (OCDE) (OECD, 2004) realizou um estudo diagnóstico das ações de Orientação Profissional em 14 de seus países-membros. No Anexo 2 do referido relatório, a OCDE resume as principais estratégias utilizadas nos países analisados no que tange a questão da Educação para a Carreira nos currículos escolares, conforme quadro 1 abaixo.

Quadro 1 - Educação para a Carreira nos currículos escolares

\begin{tabular}{|c|c|}
\hline País & Resumo \\
\hline Austrália & $\begin{array}{l}\text { O momento em que a Educação para a Carreira se dá no currículo varia. Em alguns casos, é } \\
\text { parte do desenvolvimento pessoal, saúde e educação física; em outros, dos estudos sociais; em } \\
\text { outros ainda, é integrada a determinados assuntos a partir do currículo. É também incluída na } \\
\text { educação para o trabalho, que pode ser ministrada apenas a alguns alunos. }\end{array}$ \\
\hline Áustria & $\begin{array}{l}\text { Todos os alunos da } 7^{\mathrm{a}} \text { e } 8^{\mathrm{a}} \text { séries devem receber } 32 \text { horas de Educação para a Carreira a cada } \\
\text { ano. Em muitos casos, isso é integrado a outros assuntos por professores de várias disciplinas, } \\
\text { muitos com pouco treinamento para isso. No Hauptschule [um dos tipos de escola secundária] } \\
\text { é oferecido como uma parte da disciplina em } 45 \% \text { dos casos. }\end{array}$ \\
\hline Canadá & $\begin{array}{l}\text { Existem diferentes formas de oferecer Orientação Profissional nas diversas províncias e } \\
\text { territórios. Por exemplo: na Columbia Britânica, em cada ano da educação infantil (até a } 12^{\mathrm{a}} \\
\text { série), } 60 \text { horas devem ser dedicadas à Educação para a Carreira e planejamento pessoal, e } 4 \\
\text { créditos devem ser obtidos em Educação para a Carreira no ensino superior. Em Saskatchewan, } \\
\text { são requeridas } 30 \text { horas de Educação para a Carreira entre a } 6^{\mathrm{a}} \text { e } 9^{\mathrm{a}} \text { séries; em Ontário, é exigido } \\
\text { um curso de meio crédito na } 10^{\mathrm{a}} \text { série; em Alberta, um curso em carreira e administração pessoal } \\
\text { é compulsório na } 11^{\mathrm{a}} \text { série. }\end{array}$ \\
\hline $\begin{array}{l}\text { República } \\
\text { Tcheca }\end{array}$ & $\begin{array}{l}\text { Educação para a carreira está incluída no currículo de todos os estudantes, da } 7^{\mathrm{a} a} \text { à } 12^{\mathrm{a}} \text { séries. As } \\
\text { escolas podem decidir como ministrá-la: em separado ou integrada a outras disciplinas. Em } \\
\text { cerca de } 25 \% \text { da escola compulsória, é oferecido como uma disciplina. }\end{array}$ \\
\hline Dinamarca & $\begin{array}{l}\text { Orientação educacional, vocacional e para o mercado de trabalho é um tópico opcional entre a } \\
1^{\mathrm{a}} \text { e } 9^{\mathrm{a}} \text { séries. }\end{array}$ \\
\hline Finlândia & $\begin{array}{l}\text { "Educação para a carreira" é obrigatória entre a } 7^{\mathrm{a}} \text { e } 9^{\mathrm{a}} \text { séries, e novas mudanças do currículo } \\
\text { requerem que seja incluída em toda a educação básica. Duas horas por semana de aulas são } \\
\text { oferecidas entre a } 7^{\mathrm{a}} \text { e } 9^{\mathrm{a}} \text { séries, e na } 10^{\mathrm{a}} \text { série e na educação profissionalizante pós-média, há } \\
\text { uma hora semanal opcional. Os estudantes de escolas vocacionais recebem uma semana e meia } \\
\text { de orientação de carreira e aconselhamento. As cidades devem oferecer e facilitar o acesso a um } \\
\text { plano sobre como a Orientação Profissional é disponibilizada como um serviço para todos e } \\
\text { também descrever as responsabilidades de diferentes atores em pesquisas transetoriais e }\end{array}$ \\
\hline
\end{tabular}




\begin{tabular}{|c|c|}
\hline & $\begin{array}{l}\text { multiprofissionais. O plano ainda deve incluir descrições dos métodos de avaliação e dos } \\
\text { programas de "Educação para a Carreira" que são oferecidos em aulas separadas, em sessões } \\
\text { de orientação individual e grupal. }\end{array}$ \\
\hline Alemanha & $\begin{array}{l}\text { As escolas incorporam o aprendizado sobre o mundo do trabalho no currículo, ou por meio de } \\
\text { temas específicos, como o estudo de tecnologias, ou de forma mais ampla ao longo de todo o } \\
\text { currículo. A Orientação Profissional é oferecida, em geral, nos dois últimos anos da escola } \\
\text { compulsória, mas pode começar mais cedo. As aulas são complementadas por visitas aos locais } \\
\text { de trabalho e por experiências neles. A Orientação Profissional foca-se muito no aprendizado } \\
\text { sobre o mundo do trabalho e pouco no autoconhecimento e desenvolvimento de metas de } \\
\text { carreira. }\end{array}$ \\
\hline Irlanda & $\begin{array}{l}\text { A disciplina "Educação para a carreira" não é obrigatória. Na educação profissionalizante, dois } \\
\text { programas, que representam juntos } 24 \% \text { dos estudantes - o Certificado de Aprovação } \\
\text { (vocacional) e o Certificado de Aprovação (aplicado) -, incluem módulos de "Educação para a } \\
\text { carreira". }\end{array}$ \\
\hline Coreia & $\begin{array}{l}\text { A disciplina "Educação para a carreira" está, no momento, sendo introduzida no currículo } \\
\text { escolar; outra disciplina, "Emprego e carreira" pode ser incluída como um tema optativo, "extra- } \\
\text { curricular", com duração de duas horas semanais, durante um semestre (total de } 68 \text { horas) - } \\
\text { ambas no Ensino Médio (junior e senior high school). Províncias e escolas decidem quanto à } \\
\text { obrigatoriedade e forma de implementação. }\end{array}$ \\
\hline Lux & $\begin{array}{l}\text { "Educação para a carreira” é obrigatória. Alguns liceus tentam implementar projetos-pilotos, } \\
\text { em que a Educação para a Carreira pode ser incluída entre as } 7^{\mathrm{a}} \text { e } 9^{\mathrm{a}} \text { séries, com duas horas } \\
\text { semanais. }\end{array}$ \\
\hline Holanda & $\begin{array}{l}\text { "Orientação facilitadora do aprendizado e trabalho" está incluída nos temas gerais, e } \\
\text { "Orientação facilitadora do setor de escolha" nos assuntos vocacionais, dentro da educação pré- } \\
\text { vocacional. Na educação geral, "Orientação na educação continuada" é um componente } \\
\text { optativo nos chamados períodos livres. }\end{array}$ \\
\hline Noruega & $\begin{array}{l}\text { No currículo, a meta é que “orientação educacional e vocacional sejam tópicos } \\
\text { interdisciplinares, vistos como responsabilidade da escola como um todo". O ensino sobre a } \\
\text { vida profissional está, em princípio, incluído no tema de cada série, como determinado pelo } \\
\text { currículo nacional para escolas de educação primária e secundária, mas tende a ser diluído em } \\
\text { vários temas gerais. Na prática, ele está presente principalmente a partir da } 8^{\mathrm{a}} \text { série e se dá em } \\
\text { diversos formatos de orientação: estima-se que há somente } 6 \text { horas na } 8^{\mathrm{a}} \text { série, } 8 \text { horas na } 9^{\mathrm{a}} \\
\text { série e } 10 \text { horas na } 10^{\mathrm{a}} \text { série, concentrada nos estudos sociais. }\end{array}$ \\
\hline Espanha & $\begin{array}{l}\text { A legislação nacional requer a Orientação Profissional em todo o sistema educacional, para } \\
\text { jovens e adultos. Uma aula semanal de Orientação Profissional, com uma hora de duração, faz } \\
\text { parte da educação compulsória primária e secundária, e dos dois anos de bacharelado da } \\
\text { educação profissionalizante pós-secundária. Na educação vocacional, são oferecidos uma } \\
\text { "orientação e treinamento vocacional” (módulo com } 65 \text { aulas anuais) e programas de } \\
\text { experiência de trabalho que são parte obrigatória do currículo nos níveis de formação } \\
\text { vocacional. }\end{array}$ \\
\hline
\end{tabular}




\begin{tabular}{|l|l|}
\hline Reino Unido & $\begin{array}{l}\text { Desde 1997, a Educação para a Carreira é parte obrigatória do currículo nacional na Inglaterra } \\
\text { para os alunos entre } 14 \text { e } 16 \text { anos; contudo, trata-se de uma disciplina extensiva, e as escolas } \\
\text { têm adotado diferentes formas de oferecer Orientação Profissional. Em 2003, o Estado anunciou } \\
\text { que a Educação para a Carreira deve ser oferecida a partir dos } 11 \text { anos e que o resultado do } \\
\text { aprendizado alcançado pelos alunos deve ser publicado. }\end{array}$ \\
\hline
\end{tabular}

Fonte: OECD (2004).

Como se pode identificar nas experiências internacionais, há uma variedade de formas de aplicação da Educação para a Carreira. Para Hoyt (2005) existem quatro conceitos básicos que fundamentam a Educação para a Carreira: o conceito de trabalho, a inclusão no currículo escolar, o desenvolvimento de hábitos e atitudes relativos ao trabalho e a colaboração entre a escola e a comunidade ocupacional.

\subsubsection{O conceito de trabalho}

O primeiro e principal fundamento da Educação para a Carreira é a ampliação do conceito de trabalho. Hoyt (2005) define o trabalho como o esforço consciente, distinto do aplicado em outras atividades não produtivas e descanso, dirigido a produzir benefícios socialmente aceitáveis para si mesmo e para outros. O elemento chave dessa definição de trabalho é a consciência, exigindo-se que a pessoa esteja comprometida com o que tenha escolhido realizar. Sendo um esforço remunerado ou não remunerado, trabalho é algo que o indivíduo que o realiza tem escolhido realizar, ao menos em parte, para saciar a necessidade humana de fazer.

Preparar as pessoas para trabalhar deveria ser um objetivo básico do sistema educativo como um todo, haja vista que a necessidade humana de trabalhar existe em todas as pessoas. É a necessidade de fazer, de conseguir, de saber que é necessária para alguém mais e que o que a pessoa faz é importante (HOYT, 2005).

Carvalho (2003, p. 15) afirma que "a categoria trabalho, na sua acepção mais ampla, se constitui em eixo para a compreensão do caráter e do sentido dos processos educacionais que ocorrem na sociedade e, de modo particular, na escola". O trabalho, núcleo estruturador da vida social, é o elemento central do desenvolvimento humano, portanto, faz-se necessária a recuperação da centralidade desta categoria nos processos educativos.

A Educação para a Carreira empenha-se para ajudar que as pessoas sejam trabalhadoras e não apenas empregados. Contrastando os sentidos das palavras trabalho e emprego, sendo o emprego entendido como os esforços involuntários para produzir benefícios para outros (HOYT, 2005, p. 17). 
Dessa perspectiva, quem trabalha sabe que o que está fazendo é importante e por que é necessário, tem confiança na sua capacidade de desempenhar suas tarefas bem, está constantemente procurando meios de se aprimorar para se superar em suas atividades e sentese orgulhoso de si mesmo orgulhando-se do que está fazendo. Enquanto aqueles que só se veem como empregados não escolheram fazer, mas ao invés disso, realizam seus deveres no emprego por não verem outras oportunidades ao seu alcance. Não gostam do que fazem, e se sentem pouco, se é que se sentem, orgulhosos de si mesmos como resultado do que fazem em seus empregos. Não lhes preocupa realizar bem suas atividades. Está constantemente procurando meios para suportarem as suas atividades. E embora exista esse contraste de sentidos, a maioria das pessoas estão procurando emprego e poucas buscando trabalho (HOYT, 2005).

Hoyt (2005) afirma que o objetivo mais importante e primordial da Educação para a Carreira é ajudar as pessoas a valorizarem o trabalho, seja ele remunerado ou não, como uma parte importante da sua trajetória de vida. E corrobora com a ideia de que a melhor maneira de valorizar o trabalho é experimentando-o.

Munhoz e Melo-Silva (2011) complementam a noção de trabalho ao afirmarem que trabalho não é apenas aquele remunerado, como a profissão, mas as atividades direcionadas a vários objetivos, em diferentes papeis e contextos ao longo da vida, como por exemplo voluntariado, trabalho realizado em casa e as atividades escolares. Nesse sentido, a proposta de Educação para a Carreira foi desenvolvida para promover uma reforma educativa que tivesse como eixo central o trabalho, aproximando a educação do mundo do trabalho.

Ao se referir a trabalho, geralmente, muitos profissionais da educação fazem a associação do termo com mercado de trabalho e tendem a rechaçar propostas educacionais, por terem uma visão reducionista da relação educação e trabalho como mera preparação para o mercado de trabalho.

Irving (2010) realiza algumas críticas aos programas de Educação para a Carreira que, em geral, pautam-se em princípios neoliberalistas, considerando os indivíduos como únicos autores de seu sucesso ou fracasso, esperando-se que eles adquiram habilidades de empregabilidade, planejem linearmente e autogerenciem sua carreira. Para suplantar essa abordagem, o autor defende as iniciativas de Educação para a Carreira que prezem pela dimensão política de preparar os estudantes para comprometerem-se democrática, ativa e criticamente em todos os aspectos da vida. Trata-se de uma filosofia crítica de justiça social que concilia o crescimento individual e a transformação social.

De fato, grande parte das propostas assumem uma visão utilitarista e focalizam apenas a questão da empregabilidade, mas é possível pensar a Educação para a Carreira para além da 
mera preparação para o mercado de trabalho, assumindo a visão de uma formação integral. Em outras palavras, pode-se contrapor a visão instrumental da Educação para a Carreira, subordinada às demandas do mercado, por uma visão crítica em que ela possibilita aos estudantes e trabalhadores enfrentarem de forma mais adequada as mudanças atuais do mundo do trabalho articulando-a com o seu projeto social (CARVALHO, 2003).

Um dos problemas dessa visão utilitarista da Educação para a Carreira é, pois, que a noção de trabalho está relacionada e submetida à lógica de mercado de trabalho e não como princípio educativo (CARVALHO, 2014). Tendo o trabalho como princípio educativo, a educação suplanta a subordinação ao mercado de trabalho ao fator empregabilidade. Nela, os conhecimentos práticos representam

\footnotetext{
um enlace entre o mundo da escola e o mundo do trabalho, pois tais conhecimentos terão que ser aprendidos primeiro na escola e devem ser trabalhados de forma integrada e em contextos semelhantes ao mundo do trabalho, de modo que os objetivos da aprendizagem se situem em um ambiente real e não se constitua em uma aprendizagem meramente teórica (CARVALHO, 2003, p. 87).
}

Segundo Hoyt (2005) a escola é trabalho (ou deveria sê-lo), a aula é um lugar de trabalho, o ensino e a aprendizagem são trabalhos, e os professores e alunos trabalhadores.

\subsubsection{O processo de ensino-aprendizagem e o desenvolvimento vocacional}

A inclusão da Educação para a Carreira no currículo escolar possibilita a fusão entre os processos de ensino-aprendizagem e de desenvolvimento vocacional (HOYT, 2005).

Munhoz, Melo-Silva e Audibert (2016) afirmam que há quatro modelos básicos de estruturação da Educação para a Carreira: o extracurricular, o de disciplina própria, o integrado a uma disciplina geral e o integrado ao currículo. A aplicação destes modelos limita-se às possibilidades do contexto educacional e do nível de ensino que será desenvolvida.

- No modelo extracurricular a Educação para a Carreira é realizada como um elemento adicional, ou seja, fora do currículo formal. São realizadas atividades diversas como seminários profissionais, visitas a centro de informação profissional, pequenos cursos em módulos projetados para ajudar os estudantes a atingirem objetivos mais imediatos ou pontuais, como tomar decisões educacionais e/ou profissionais.

- No modelo de disciplina própria a Educação para a Carreira é desenvolvida como um assunto ou módulo separado dentro do currículo. As atividades realizam-se no horário escolar, num programa sistemático de desenvolvimento profissional com 
duração superior a um ano, sob a orientação de um professor ou de um orientador profissional.

- No modelo integrado a uma disciplina geral a Educação para a Carreira é ofertada como parte de um assunto ou módulo mais amplo dentro do currículo. As atividades fazem parte de uma disciplina mais geral, ministrada pelo professor da matéria ou ainda por um orientador profissional.

- No modelo infuso ou integrado ao currículo a Educação para a Carreira está integrada no currículo como um todo, disseminando transversalmente nos conteúdos curriculares objetivos de aprendizagem relevantes ao desenvolvimento vocacional.

É um grande desafio integrar o desenvolvimento vocacional nos currículos em enfoques educativos. Guichard e Huteau (2002, p. 292) advertem que a infusão, quando sistematicamente conduzida, tem a "vantagem de se abrir os ensinos à vida, mas comporta igualmente um risco, o de introduzir nos ensinos um utilitarismo excessivo".

Um dos diferenciais da Educação para a Carreira das demais abordagens de OVP, é que ela se constitui em uma abordagem escolar. A integração orgânica do processo de ensinoaprendizagem e o processo de desenvolvimento vocacional requer o protagonismo dos profissionais de ensino, portanto o fundamento das ações a serem desenvolvidas, não reside em métodos psicométricos, mas em atividades pedagógicas pertinentes a atuação do docente e tendo como eixo central a categoria trabalho (CARVALHO, 2014).

As alternativas de futuro, dialogadas e mediadas por um professor, talvez podem só ser possíveis, a partir dessas oportunidades pedagógicas específicas. Essa abordagem, portanto, pode abrir possibilidades que talvez não ocorressem sem tais mediações. Os programas de Educação para a Carreira, vinculados aos currículos escolares e articulados com o mundo do trabalho, possibilitam a suplantação do caráter marcadamente clínico das experiências de OVP por um enfoque pedagógico da questão.

O enfoque educacional da Educação para a Carreira, permite a conciliação de dois métodos pedagógicos: o cognitivo, que se baseia na transmissão de informações; e o experiencial, que envolve dinâmicas de grupo e situações vivenciais (CARVALHO, 2014). É possível projetar-se em papéis ocupacionais através da capacidade elaborativa como também vivenciar escolhas e decisões por técnicas específicas e tratá-las cognitivamente.

Usualmente, pode-se afirmar que os conteúdos dos programas de Educação para a Carreira consistem nos seguintes componentes gerais: autoconhecimento; conhecimento de oportunidades de estudo e trabalho; aprendizagem de processos de tomada de decisões; e aprendizagem do manejo com as transições (MUNHOZ, MELO-SILVA E AUDIBERT, 2016). 
As atividades de Educação para a Carreira deveriam iniciar juntamente com o processo de escolarização, desde a educação infantil. Desenvolvendo-se, de acordo com os níveis de maturidade o planejamento educacional e da carreira, concomitantemente à estruturação dos conceitos de si próprio e de trabalho. Rodríguez Moreno (2008) discute a aplicação da Educação para a Carreira desde a infância e ressalta a necessidade de considerar o nível de desenvolvimento das crianças e adolescentes adequando-a aos objetivos para cada etapa.

Aos poucos as pessoas vão compreendendo a importância, pois a temática passa a ser amplamente discutida. Assim, os indivíduos passam a reconhecer a necessidade de se programar, de decidir e de escolher. Dessa forma, quando chegarem nos momentos de transição se sentirão mais seguros, pois já trataram cognitivamente essas experiências.

A OVP no contexto escolar, por meio da Educação para a Carreira, pode ser desenvolvida por meio da atuação de um professor ou do orientador educacional. Caso um professor desenvolva esse trabalho, o orientador educacional e o psicólogo escolar podem articulados, assessorar este trabalho pedagógico.

Ao discorrer sobre os possíveis agentes da Educação para a Carreira, Carvalho (2014) defende a adequação para a ação do pedagogo devido ao caráter educacional dessa abordagem. Conforme a Resolução CNE/CP $n^{\circ} 1$, de 15 de maio de 2006, que institui as Diretrizes Curriculares para o Curso de Graduação - Licenciatura em Pedagogia, a formação do Pedagogo o habilita para o exercício da docência para a educação infantil e séries iniciais do ensino fundamental, mas também para o exercício da docência nos cursos de ensino médio e em outras áreas nas quais sejam previstos conhecimentos pedagógicos. A atividades do docente pedagogo, ainda de acordo com a referida Resolução, engloba a participação no planejamento, execução, coordenação, acompanhamento e avaliação de projetos e programas educacionais, em ambientes escolares e não-escolares. Portanto, de acordo com a normatização brasileira, seria possível suplantar uma das principais dificuldades que ocorrem internacionalmente na instauração da Educação para a Carreira: A presença do pedagogo na escola permite superar um dos obstáculos mais correntes
na implementação de programas de Educação para a Carreira em âmbito mundial, que
é a rejeição por parte dos professores de atribuição de mais uma atividade que, embora
eles considerem importante, não possuem preparo para exercê-la, além de que esta
implica sobrecarga de trabalho. O pedagogo é um profissional da educação com
múltiplas funções, podendo exercer suas ações educativas em diversos contextos
formativos (CARVALHO, 2014, p. 106). 


\subsubsection{O desenvolvimento de hábitos e atitudes relativos ao trabalho}

Munhoz e Melo-Silva (2011, p. 38) apontam "a escola, como lugar de aprendizado, convivência e formação, apresenta-se como espaço privilegiado para o desenvolvimento de hábitos, atitudes, valores, habilidades e pensamento crítico". A escola é uma instituição que tem um papel fundamental de educar e socializar os indivíduos, ela forma as competências dos indivíduos.

A Educação para a Carreira considera que os hábitos e atitudes relativos ao trabalho começam a desenvolver-se na infância, e os contextos familiar e escolar influenciam marcadamente sobre o desenvolvimento da carreira (MUNHOZ; MELO-SILVA, 2011, p. 39). O contexto cultural e a socialização escolar a qual o estudante terá acesso propiciarão o desenvolvimento de representações, hábitos e atitudes em relação ao trabalho.

Hoyt (2005) elencou algumas competências básicas que são desenvolvidas na Educação para a Carreira: as habilidades acadêmicas básicas; bons hábitos de estudo; o desenvolvimento e a utilização de um conjunto de valores de trabalho; o conhecimento de si mesmo e conhecimento das oportunidades educativas e profissionais disponíveis e habilidades para tomar decisões na carreira.

King (2007 apud MUNHOZ; MELO-SILVA, 2011, p. 39) sugere que temas como responsabilidade, consciência de carreira, pontualidade, habilidade de ouvir e prestar atenção, saber se avaliar e aprender com os erros devem ser desenvolvidos tanto para a aprendizagem escolar como para o futuro desempenho na profissão. A escola pode possibilitar que os alunos se vejam como pessoas produtivas, participantes do mundo do trabalho, nas suas múltiplas possibilidades. Também é na escola que se forjam competências para que os indivíduos possam se orientar, gerir a sua carreira, ajudando-os não somente a fazer escolhas imediatas que se deparam, mas proporcionar metodologias de escolha e desenvolvimento da carreira que possam ser utilizadas ao longo da vida.

A Educação para a Carreira tem como pressuposto o fato de que o "desenvolvimento vocacional não se resolve em uma escolha ou decisão, ao contrário, se descobre e se constrói ao longo da vida" (CARVALHO, 2014, p. 96). Portanto, a OVP não se concentra em períodos específicos, pois entende-se que ao longo da vida os indivíduos o tempo todo realizam escolhas, e prepara com mais segurança os trabalhadores para o desafio da empregabilidade e para a capacidade de fazer a autogestão da carreira. 


\subsubsection{A colaboração entre a escola e a comunidade ocupacional}

Na Educação para a Carreira a colaboração entre a escola e a comunidade ocupacional ou profissional traduz-se em uma parceria na qual autoridade, responsabilidade e avaliação são compartilhadas conjuntamente (HOYT, 2005). Para que a Educação para a Carreira tenha êxito, é necessário que se consolide parcerias que se envolvam e assumam responsabilidades colaborativamente.

Munhoz e Melo-Silva (2011, p. 39) afirmam que o "envolvimento da comunidade não é apenas para ajudar, mas também assumir responsabilidades no planejamento, treinamento, execução e avaliação". Trata-se de uma ação conjunta e intersetorial da sociedade, na qual cada um contribui na medida das suas possibilidades e competências.

O conceito de educação é muito mais amplo do que escolarização, muitas oportunidades educativas para além daquelas que existem no sistema formal de escolaridade, estando dispostas na sociedade. E as necessidades educacionais contemporâneas não se satisfazem apenas com escolarização formal sozinha, é necessário que os professores aprendam e usem os recursos comunitários. É necessário que haja uma mudança de relação entre essas instâncias.

\subsubsection{Os benefícios da Educação para a Carreira}

Munhoz, Melo-Silva e Audibert (2016) afirmam que a Educação para a Carreira pode ir ao encontro das necessidades de desenvolvimento da carreira dos alunos: começar a preocupar-se com o futuro; aumentar gradativamente o controle de sua vida; convencer-se da importância das atividades escolares e de trabalho; adquirir habilidades e atitudes de trabalho; autoconhecimento; conhecimento do mundo profissional; experimentação de papéis sociais e ocupacionais na escola, no lazer ou em trabalhos de tempo parcial.

Por meio da implantação da Educação para a Carreira é possível realizar o desenvolvimento do sentido e da importância do trabalho e a preparação do indivíduo para o trabalho, em sua acepção mais ampla. Inserida no ensino regular, ela pode auxiliar o jovem a lidar com as transições para a vida social adulta e as relacionadas a carreira.

Acolher essa abordagem, implica em uma reforma educacional que propiciará aos estudantes, com atividades pedagógicas, relacionarem educação e trabalho para o desenvolvimento da carreira possibilitando a cada um fazer do trabalho, remunerado ou não, uma parte significativa do seu projeto de vida.

A escola ao desenvolver a orientação profissional e vocacional possibilita aos jovens refletirem e conceberem os seus projetos de vida, que implicam na concepção de si próprios, 
tendo em vista que "o homem nada mais é do que o seu projeto, só existe na medida em que se realiza; não é nada além do conjunto de seus atos, nada mais que sua vida" (SARTRE, 1987, p. 13).

É preciso levar em consideração que "o homem como projeto de ser que se realiza sempre a partir, tanto das condições dadas e presentes, como também das relações passadas que delimitam quem é ou se tornou até então" (EHRLICH, CASTRO E SOARES, 2000, p. 76). Contribui-se para a realização vocacional dos indivíduos, ou seja, a Educação para a Carreira pode ser vista como um instrumento que possibilita a realização dos sujeitos enquanto seres humanos.

Além dos aspectos aludidos anteriormente é importante destacar que a Educação para a Carreira pela sua importância e legitimidade ao ser instituída pode se constituir em uma política pública de transformação social.

A escola não pode pensar endogenamente, com seus estudos desvinculados das práticas sociais e do mundo do trabalho e também não pode pensar a curto prazo, como se a sua atuação não tivesse reverberações futuras. A escola é o local no qual as pessoas devem ser preparadas para os seus projetos de vida, serem preparadas para serem bem-sucedidas em suas trajetórias pessoais, ocupacionais e profissionais.

Alguns sistemas de ensino possuem iniciativas incipientes de OVP no âmbito escolar, merecendo mais destaque à compreensão e ao conhecimento do mundo do trabalho, desvelando-se o contexto social e contribuindo para a emancipação social refletida e não a sua reprodução mecânica.

Uma vez caracterizados os pressupostos básicos da Educação para a Carreira e ante às potencialidades que a adoção dessa abordagem pode trazer para a sociedade, no sentido de transformar o entendimento e ampliar a percepção dos estudantes preparando-os para a realização de escolhas e tomada de decisões em seu Projeto de Vida, cabe refletir sobre o papel das representações sociais nesse contexto.

As representações sociais são um tipo de conhecimento do senso comum por meio do qual os indivíduos desenvolvem a sua compreensão da realidade e guiam-nos à ação. Suspeitase que a forma como os jovens compreendem e representam os temas vocacionais influenciam nas suas decisões e isso tem consequências, pois, caso tais representações não sejam orgânicas e consistentes as escolhas também não serão, gerando instabilidade, insegurança e vulnerabilidade que refletem em outras esferas da vida social. 
Por essa razão, considera-se essencial, que se dedique uma seção deste trabalho para apresentar reflexões acerca da Teoria das Representações Sociais e da Praxiologia de Bourdieu, conjunção teórico-metodológica basilar para esta investigação.

\subsection{A TEORIA DAS REPRESENTAÇÕES SOCIAIS (TRS) E A PRAXIOLOGIA DE BOURDIEU}

Domingos Sobrinho (2014) desenvolveu um modelo teórico que articula a TRS do psicólogo Serge Moscovici e os postulados da Praxiologia do sociólogo Bourdieu. A articulação ainda se constitui em uma novidade, que nos últimos anos vem ganhando espaço nas pesquisas educacionais brasileiras. Trata-se de uma perspectiva psicossocial, na qual a TRS, predominantemente psicológica é complementada pela Praxiologia que supre suas lacunas sociologicamente. Ambas teorias possibilitam a conjunção e análise das dimensões material e simbólica dos estudantes.

Com apoio na TRS é possível investigar os significados ou sentidos enquanto produção coletiva, comunicada e compartilhada por um grupo que serve como guia para ação, já na Praxiologia apreende-se as condições materiais da produção dessas representações, identificando as relações de poder, os aspectos culturais, as imposições ideológicas e a naturalização do mundo social.

As representações sociais, com base em Moscovici e Jodelet, são socialmente elaboradas e partilhadas e visam à construção de uma realidade comum a um conjunto social, referem-se a um sistema de preconcepções, de imagens e valores que detém significação cultural própria e que sobrevivem independentemente das experiências individuais, sendo construídas involuntariamente. Tais representações não são apenas cognitivas, mas socialmente elaboradas e contribuem para a orientação de condutas e comunicação de um determinado grupo (DOMINGOS SOBRINHO, 2014). A representação social é uma totalidade significante, envolvendo percepção, concepção, imagem, opinião e atitude.

A partir da TRS é possível responder: Quem sabe? De onde sabe? O que sabe? Como sabe? Sobre o que sabe? E com que efeitos? (DOMINGOS SOBRINHO, 2014). Existe, porém, uma indagação que a TRS não é capaz de responder: A partir de que condições sabe? É diante dessa lacuna que, Domingos Sobrinho (2014) propõe um diálogo entre a TRS de Moscovici e a sociologia da cultura ou praxiologia de Bourdieu.

Além das concepções elaboradas pelos indivíduos, a partir de Bourdieu, é possível considerar que as condições sociais influenciam e permitem aos sujeitos construírem suas 
representações e serem quem são. Na sua teoria do mundo social, ele articula alguns elementos importantes para realizar essa análise: o habitus, o capital cultural e o campo social.

O habitus é constituído a partir das experiências e das condições sociais de existência dos indivíduos, tais estruturas objetivas são interiorizadas sob a forma de esquemas de percepção e entendimento e de princípios inconscientes de ação e reflexão coletivamente orquestradas. O habitus é a categoria dialética entre a objetividade e a subjetividade: ele produz representações, percepções e todas as outras produções simbólicas que articulam o agente social e a estrutura social. O habitus é composto por três dimensões: eidos, ethos e hexis.

Eidos é a dimensão cognitiva e funciona como orientação prática relacionando-se com o cálculo de possibilidades e antecipação do futuro. Os sujeitos sentem e presentem, por meio da eidos, pois através dela os eventos são decifrados, avaliados, prospectados e selecionados. A eidos fornece subsídios para escolhas, pois os sujeitos podem avaliar as chances e oportunidades que se ajustam às suas possibilidades.

Ethos é a dimensão ética de modo espontâneo, natural e não necessariamente consciente, ela refere-se aos valores atribuídos e às normas de comportamento dos sujeitos.

Hexis é a dimensão corporal e exteriorizada de toda a história internalizada dos indivíduos, tratam-se dos gestos e movimentos corporais, posicionamentos, o estilo de vida dos sujeitos e sua linguagem.

O capital cultural refere-se ao montante de bens materiais ou simbólicos que tenham significados culturais e são elementos que influenciam nas posições sociais no campo social.

O campo social, por sua vez, é um lugar de relações de força e de mercado de bens simbólicos, nele os agentes enfrentam-se conforme suas posições e interesses contribuindo para conservar ou transformar tal estrutura.

Através desses elementos, compreende-se que as trajetórias social, familiar e escolar dos indivíduos e os capitais acumulados por eles nesse itinerário condicionam a inserção nos campos sociais por nós investigados. O agente não está aprisionado no determinismo desses elementos, pois o conhecimento destes ajuda na sua libertação (DOMINGOS SOBRINHO, 2014).

De acordo com Domingos Sobrinho (2014) é a partir dessa matriz TRS-Praxiologia que se pode realizar a leitura da construção dos sentidos atribuídos a objetos realizados pelos indivíduos de um determinado grupo.

A análise das representações sociais é uma estratégia promissora para se alcançar os propósitos educacionais. E no que tange a questão da OVP, a construção, o funcionamento das representações sociais dos estudantes para interpretar a realidade e a sua função orientadora de 
condutas e das práticas sociais, reforçam a interferência desses mecanismos para a construção da identidade vocacional e profissional dos educandos. Conhecer esses aspectos permite compreender e conhecer formas para intervir adequadamente transformando e ampliando o entendimento e as atitudes dos estudantes, visando a função transformacional da educação.

Ao investigar as representações sociais perscruta-se as significações e teorias que os indivíduos elaboram sobre um determinado objeto, ao passo que elas também trazem indícios de como as ações e comportamentos de indivíduos do grupo são orientados. Mas no processo de apreender o objeto em sua totalidade, as representações sociais precisam ser conhecidas, consideradas e relacionadas com os aspectos culturais, a intencionalidade e as contradições que carregam.

Com base nas discussões e teorias apresentadas partiu-se para a pesquisa empírica, buscando-se a identificação o conteúdo e a estrutura das representações sociais dos estudantes acerca de todo esse contexto e oferecendo-se elementos para cotejar as percepções e necessidades do público investigado e os pressupostos básicos da Educação para a Carreira. 


\section{METODOLOGIA}

Esta dissertação tem como propósito analisar o papel da Educação para a Carreira na ampliação das representações sociais dos estudantes e na preparação para a realização de escolhas e tomada de decisões em seu Projeto de Vida. Para levar a cabo este objetivo, escolheuse um quadro de referências teórico-epistemológicas que possibilite a articulação dos processos macroestruturais e das relações microssociais do objeto investigado. Considerando essa complexidade e com o intuito de alcançar a totalidade do fenômeno investigado adotou-se neste estudo a abordagem crítico-dialética e o modelo teórico desenvolvido por Domingos Sobrinho (2014) que articula a TRS de Serge Moscovici e a Praxiologia de Bordieu.

Como metateoria, utilizou-se a abordagem crítico-dialética, para questionar a OVP em suas multideterminações tendo como fundamento um interesse investigativo críticoemancipador que desvenda as contradições e as potencialidades de transformação social (GAMBOA, 2008) e também porque essa abordagem

\footnotetext{
busca apreender o fenômeno em seu devir histórico e em suas inter-relações com outros fenômenos, buscando compreender os processos de sua transformação, suas contradições e potencialidades de mudança. [...] O conhecimento crítico do mundo e da sociedade e a compreensão de sua dinâmica transformadora propiciam ações (práxis) emancipadoras. A práxis elevada a categoria epistemológica fundamental se transforma em critério de verdade e de validez científica. A práxis significa reflexão e ação sobre uma realidade buscando sua transformação. (GAMBOA, 2008, p. 173).
}

Esse método é oportuno, pois a concepção que se tem é que a realidade estudada, a OVP no contexto educacional, é multideterminada por aspectos políticos, econômicos, sociais e culturais. Essa realidade constrói historicamente os sujeitos, os estudantes, que são seres sociais que por sua vez se transformam e transformam a realidade que participam. Além disso, considera-se que a história é compreendida na dialética, na dinâmica e nos conflitos dos contrários, representada pelos diferentes interesses.

Em combinação à abordagem crítico-dialética, optou-se pelo modelo teórico desenvolvido por Domingos Sobrinho (2014) que articula a TRS de Serge Moscovici e a Praxiologia de Bordieu. Por meio dele apontou-se como o habitus estudantil gesta a construção da representação social de aspectos relativos à escola, à sua função, à sua relação com a OVP e à escolha de uma carreira ou profissão servindo de guia para as suas ações no contexto escolar e na transição escola-trabalho.

Nessa conjunção teórico-epistemológica é possível evidenciar a relação entre os aspectos macro e microssociais e como esses influenciam nas trajetórias dos agentes construtores das representações sociais sobre as temáticas vocacionais que, por sua vez, servem 
de guia para as suas ações. Assim, evidencia-se uma articulação entre as questões de ordem material e simbólica dos sujeitos tomada em uma perspectiva dialética e aponta-se indícios para possíveis intervenções visando a transformação da realidade.

O reconhecimento das representações sociais possibilita analisar como se desenvolve a assimilação do processo de OVP, mesmo que não institucionalizado, no sistema de ensino em questão, esclarecendo e levantando as expectativas dos estudantes, além de fornecer elementos para se refletir sobre a necessidade da inclusão curricular da OVP, e as possibilidades de que ela possa se constituir em uma política pública para o sistema de ensino em questão.

A metodologia desta investigação baseia-se na pesquisa empírica com alunos de uma unidade escolar de ensino médio de tempo integral da rede pública de ensino do Distrito Federal. Esta investigação, embora lance mão de alguns aspectos quantitativos, é de abordagem predominantemente qualitativa que, conforme as características elencadas por Bogdan e Biklen (1994) a fonte direta de dados é o ambiente natural, constituindo o investigador o instrumento principal; é descritiva; interessa-se mais pelo processo do que simplesmente pelos resultados ou produtos; tendem a analisar os dados de forma indutiva e; o significado é de importância vital.

A adequação da escolha da predominância dessa abordagem pode ser evidenciada em relação ao interesse de analisar o modo como os estudantes representam os objetos sociais investigados. Assim sendo, o significado e as suas determinantes são imprescindíveis. Além disso, a análise do processo de construção das representações merece mais atenção do que os resultados e o produto propriamente dito e a fonte direta de dados é o ambiente natural no qual a população investigada se encontra.

\subsection{LÓCUS DA PESQUISA E POPULAÇÃO INVESTIGADA}

Inicialmente, objetivando conhecer o campo social que se investigou, realizou-se um levantamento de dados secundários sobre a Região Administrativa, na qual reside a maioria dos estudantes e onde está situada a unidade escolar investigada.

Taguatinga é uma das Regiões Administrativas do Distrito Federal, está localizada a 19 km de Brasília e foi fundada em 5 de junho de 1958 em função do superpovoamento da localidade em que atualmente é a Região Administrativa do Núcleo Bandeirante, que não tinha condições para abrigar o grande número de trabalhadores que chegavam de toda parte do país para a construção da nova capital. Devido ao crescimento da população e diante da necessidade de novos espaços habitacionais, ocorreu o desmembramento do seu território dando origem a 
duas outras regiões, Ceilândia e Samambaia, regiões administrativas de maior densidade demográfica do Distrito Federal e que são zonas de extrema vulnerabilidade social (CODEPLAN, 2016).

Para caracterização socioeconômica da região, destaca-se que, de acordo com os dados da Pesquisa Distrital por Amostra de Domicílios da Companhia de Planejamento do Distrito Federal (CODEPLAN) (2016), Taguatinga tem a população estimada de 222.598 habitantes, a renda domiciliar média mensal é de $\mathrm{R} \$$ 6.072,92, os ocupados desempenham atividades predominantemente no comércio, $28 \%$, serviços gerais, $16 \%$ e serviços pessoais, $15 \%$ e a escolaridade da população de Taguatinga concentra-se no nível médio completo, 27\%, seguido pelo superior completo, $22 \%$.

Inserida neste contexto, encontra-se a instituição de ensino médio ofertante de ensino médio que é o lócus específico desta pesquisa. Trata-se de uma unidade escolar integrante da estrutura da Secretaria de Estado de Educação do Distrito Federal (SEEDF) e participante do programa Ensino Médio em Tempo Integral (EMTI).

$\mathrm{Na}$ SEEDF, doze unidades escolares aderiram ao Programa de Fomento à Implementação de EMTI e que atualmente ainda ofertam educação em tempo integral, tal política foi instituída pela Lei $\mathrm{n}^{\mathrm{o}} 13.415$, de 16 de fevereiro de 2017, buscando apoiar a ampliação da oferta de educação de EMTI nas redes públicas dos Estados e do Distrito Federal.

A escolha por uma unidade escolar que participe desse programa deve-se ao fato de que os projetos-piloto de atividades com OVP, sob a denominação de Projeto de Vida, em outras Secretarias de Educação iniciaram-se no âmbito desta política, provavelmente pela ampliação da jornada escolar e pela flexibilidade curricular, características inerentes ao programa.

Os sujeitos investigados neste estudo são estudantes da $3^{\mathrm{a}}$ série do ensino médio da referida instituição, que são três turmas e, atualmente, totalizam-se 80 estudantes matriculados. A escolha por alunos da $3^{\text {a }}$ série ocorreu em virtude de serem concluintes da última etapa da educação básica e poderem testemunhar as oportunidades e as suas experiências que tiveram relacionadas às questões da OVP no sistema de ensino em foco e ao longo da sua trajetória escolar.

\subsection{TÉCNICAS E INSTRUMENTOS DE PESQUISA}

As técnicas empregadas para a geração de dados da pesquisa empírica foram o questionário socioeconômico e cultural e o Teste de Associação Livre de Palavras (TALP). 
O primeiro instrumento utilizado foi o questionário socioeconômico e cultural com 24 questões de múltipla escolha ou questões abertas, com o intuito de apreender os referentes empíricos do habitus estudantil, destacando-se os costumes, experiências, percepção de influência, motivações, aspirações e outras regularidades do ser estudante deste espaço social.

O TALP, segundo instrumento empregado, consiste no preenchimento de palavras relacionadas à expressão indutora além dos sujeitos selecionarem a mais importante e justificarem a atribuição da importância àquela palavra. Dessa forma, os participantes têm a oportunidade de refletirem e exteriorizarem as suas representações. Tal técnica possibilita evidenciar as palavras que se agrupam e combinam para determinadas populações apreendendo os elementos simbólicos de uma representação (ABRIC, 1998). O emprego desse instrumento deveu-se ao fato de que um dos intentos era evidenciar a estrutura e o conteúdo das representações sociais, por isso optou-se pela Teoria do Núcleo Central, uma técnica desenvolvida por Jean-Claude Abric (1998) cujo enfoque é a abordagem estrutural da representação social. Nela determina-se o núcleo central e os elementos periféricos de uma representação social. O TALP, portanto, mostrou-se adequado para tal abordagem.

Por meio do registro desses instrumentos além de coletar o conteúdo das representações sociais dos estudantes sobre a escola, a sua função, a sua relação com a OVP e a escolha de uma carreira ou profissão, também tinha a pretensão de, através dos cruzamentos de dados, realizar inferências explicativas sobre as representações sociais utilizando-se das informações geradas no questionário socioeconômico e cultural.

A técnica empregada para realizar a análise de dados do questionário e do TALP é a análise de conteúdo que segundo Bardin (1977, p. 42) visa "obter por procedimentos, sistemáticos e objetivos de descrição do conteúdo das mensagens, indicadores que permitam inferências de conhecimentos relativos às condições de produção/recepção destas mensagens". Através dessa análise é possível aproximar e construir inferências a respeito do habitus estudantil, como uma via de acesso às representações sociais da população investigada, bem como estas possibilitam uma proximidade daquele.

\subsection{PROCEDIMENTOS DE COLETA DE DADOS}

Para iniciar o procedimento de levantamento de dados da pesquisa empírica, o pesquisador realizou uma visita na instituição de ensino no dia 22 de abril de 2019 e por meio de um contato verbal com o vice-diretor recebeu o acesso à instituição uma vez que este mostrou-se favorável à proposta da investigação. O vice-diretor da unidade de ensino em 
questão encaminhou o pesquisador à orientadora educacional a fim de que juntos pudessem escolher a melhor estratégia para realizar a apresentação e a aplicação dos instrumentos de pesquisa.

A orientadora educacional sinalizou que na semana seguinte haveria uma ocasião favorável para a realização da pesquisa, ela cederia um momento do pré-conselho de cada uma das turmas, pois não comprometeria o horário das aulas haja vista que o dia e horários já estavam previamente agendados. É de praxe na referida instituição que no fim de cada bimestre cada turma realize o pré-conselho, que é uma espécie de reunião na qual todos os estudantes da turma têm a oportunidade de se pronunciarem e darem um feedback em relação às fragilidades e potencialidades do trabalho pedagógico e de outros aspectos que possam interferir no processo de ensino-aprendizagem, sob a liderança dos representantes de turma e a mediação da orientadora educacional.

No dia 29 de maio de 2019, em cada um dos três horários do turno matutino, ocorreu a aplicação dos instrumentos de pesquisa com cada uma das turmas. Em cada horário a orientadora educacional foi a sala de aula chamar os alunos para se dirigirem à sala de vídeo, quando já acomodados ela apresentou o pesquisador, que teve a oportunidade de expor o objetivo da pesquisa e explicar que ela é composta por dois momentos, e que caso alguém não quisessem participar da pesquisa ou de algum de seus momentos, poderia sentir-se à vontade para declinar.

O primeiro momento foi realizado na própria sala de vídeo, entregou-se uma folha com o Termo de Consentimento Livre e Esclarecido - TCLE para cada estudante (Apêndice A), que consta a manifestação de compreensão do objetivo e interesse em participar da pesquisa. Foi explicado oralmente os principais pontos e solicitado que após concordarem com a participação virassem o verso da folha, para realizarem o TALP, principal instrumento de coleta do conteúdo das representações sociais em estudo. Embora o próprio formulário fosse autoexplicativo, instruiu-se coletiva e oralmente que a atividade consistia no preenchimento de quatro frases incompletas com três palavras ou expressões curtas que, espontaneamente, sem pensar muito, lhes viessem à cabeça ao lerem as frases incompletas; que escolhessem a mais importante assinalando um X e; justificassem a escolha. Com o intuito de atrair a atenção dos estudantes, o TCLE e o TALP foram impressos em papel amarelo e a apresentação da pesquisa e suas condições foi bem sucinta. Dos 80 estudantes matriculados, 59 realizaram o TALP e os 21 restantes estavam ausentes ou se abstiveram de participar.

Após terminarem o preenchimento do TALP, os alunos sinalizaram a finalização, entregaram-nos e foram sendo orientados a dirigirem-se para o laboratório de informática. Com 
o auxílio da Educadora Social Voluntária responsável pelo recinto, os estudantes tiveram acesso ao endereço eletrônico do questionário socioeconômico e cultural (Apêndice B) disponibilizado por meio da plataforma Google Formulários $^{1}$ na qual os eles puderam compartilhar seus costumes, experiências, percepção de influência, motivações e aspirações. Dos 80 estudantes matriculados, 55 responderam o questionário online e os 25 restantes estavam ausentes ou se abstiveram de participar. Conforme finalizavam os alunos retornavam à dinâmica programada para o dia.

Após o procedimento de coleta de dados gerados empiricamente, o pesquisador realizou a tabulação e análise destes, na qual discute em torno deles e relaciona-os com as contribuições teóricas, interpretando-os e atribuindo-lhes significados.

\subsection{ANÁLISE/INTERPRETAÇÃO DOS RESULTADOS}

Para realizar a análise dos resultados dessa investigação, partiu-se de um dos pressupostos básicos do modelo teórico-metodológico desenvolvido por Domingos Sobrinho (2014), o de que o habitus de um determinado grupo se constitui em uma via de acesso às representações sociais, assim como estas permitem uma aproximação daquele. Desse modo, preferiu-se iniciar com a interpretação dos dados referentes ao questionário socioeconômico e cultural, construído com o intuito de apreender os referentes empíricos do habitus estudantil investigado. Por esse caminho, conseguiu-se desvelar determinadas regularidades socioeconômicas e culturais condicionantes da atual posição ocupada por esse grupo de estudantes no campo social.

Caracterizar os participantes da pesquisa é responder as questões que norteiam o modelo teórico-metodológico escolhido para esta investigação, dentre as quais destaca-se "quem sabe?”, “de onde sabe?” e "a partir de que condições se sabe?" (DOMINGOS SOBRINHO, 2014). Apresenta-se abaixo o perfil dos estudantes, por meio de seus dados socioeconômicos e culturais apreendidos através do questionário.

A maior parte da população é constituída por estudantes do sexo masculino, 54,5\%. Do total de estudantes que participaram da pesquisa, a maioria dos estudantes $(92,8 \%)$ têm 17 ou 18 anos, ou seja, estão dentro da idade prevista para a série. Um estudante tem 19 anos ou mais e três estudantes têm 16 anos ou menos.

\footnotetext{
${ }^{1}$ O Google Formulários é um serviço da empresa Google que tem por objetivo facilitar a criação de formulários e questionários diversos.
} 
Quando questionados em relação ao tipo de estabelecimento que cursaram a educação básica (ou seja, educação infantil, ensino fundamental e ensino médio), a parte majoritária (60\%) afirmou toda em escola pública, seguidos por 17 estudantes $(30,9 \%)$ que afirmaram maior parte em escola pública e por 5 estudantes $(9,1 \%)$ que indicaram maior parte em escola particular sem bolsa.

Quanto ao nível de escolaridade do pai, a população concentra-se na categoria dos que têm nível médio completo $29,1 \%$, seguida pelo ensino fundamental incompleto $20 \%$, ensino médio incompleto $18,2 \%$ e ensino fundamental completo $8 \%$. Os que possuem graduação completa são $7,3 \%$, graduação incompleta $5,5 \%$ e não alfabetizados $5,5 \%$.

A profissão/ocupação do genitor dos estudantes, em geral, podem ser classificadas como predominantemente manuais, de baixa qualificação e remuneração. Algumas ocupações levantadas, dentre outras, foram: agricultor, ajudante de pedreiro, motorista, comerciante, mecânico e eletricista. De acordo com as informações fornecidas, quatro pais encontram-se desempregados.

No tocante ao nível de escolaridade da mãe, a população concentra-se na categoria das que têm nível médio completo 38,2\%, seguida pelo ensino fundamental incompleto 18,2\%, ensino médio incompleto $14,5 \%$. As que possuem graduação completa são $9,1 \%$, graduação incompleta $9,1 \%$, pós-graduação completa $5,5 \%$ e ensino fundamental completo 5,5\%. Identifica-se que os níveis de escolaridade das mães dos estudantes são maiores que os níveis de escolaridade dos pais, elas já alcançam o nível da pós-graduação enquanto eles ainda não e elas já superaram o analfabetismo enquanto ainda há pais não-alfabetizados.

A profissão/ocupação da genitora dos estudantes, em geral, também podem ser classificadas como predominantemente manuais, de baixa qualificação e remuneração. Algumas ocupações levantadas, dentre outras, foram: cuidadora, doméstica, auxiliar de serviços gerais, vendedora, diarista e manicure. A presença de ocupações de nível mais elevado ocorreu com mais frequência entre as mães do que entre os pais, entretanto o quantitativo de mães desempregadas, onze, foi bem superior ao de pais desempregados, quatro.

Quando perguntados acerca da frequência com que os familiares costumam conversar com estudantes sobre carreiras ou profissões, 45,5\% afirmaram que frequentemente, 34,5\% disseram que às vezes, $12,7 \%$ indicaram que raramente e 7,3\% relataram que nunca.

Ao serem indagados sobre com que regularidade os seus colegas costumam conversar com eles sobre carreiras ou profissões, 45,5\% dos alunos disseram que às vezes, 38,2\% indicaram que frequentemente, $14,5 \%$ relataram que raramente e $1,8 \%$ afirmaram que nunca. 
Quanto à periodicidade com que a escola costuma realizar atividades e conversar com eles sobre carreiras ou profissões, 41,8\% relataram que raramente, 29,1\% afirmaram que às vezes, $23,6 \%$ disseram que nunca e 5,5\% indicaram que frequentemente.

Em relação ao costume de pesquisar ou ler sobre carreiras ou profissões, 45,5\% indicaram fazê-lo frequentemente, 38,2\% relataram que o fazem às vezes, 9,1\% afirmaram que raramente fazem e 7,3 disseram que nunca.

Diante dos dados, identifica-se que em relação à frequência, a conversa com familiares e a pesquisa ou leitura individual são as principais fontes de informação profissional dos estudantes, seguida pela conversa com colegas e, por último, a escola.

No que concerne a ordem de importância dos setores, instituições e pessoas que influenciam a OVP deles, os dados levantados com os estudantes apontam que são respectivamente: os familiares, a pesquisa ou leitura individual, a mídia, a escola e, por fim, os colegas.

Outro achado importante a considerar nesta caracterização dos estudantes foi que enumerando por ordem de importância os fatores que eles consideram que mais os influenciarão no momento da escolha de uma profissão ou carreira, os dados levantados apontam que são: primeiro, a possibilidade de autorrealização através do trabalho, segundo, a vocação, terceiro, as perspectivas de ganho financeiro, quarto, as oportunidades do mercado de trabalho, quinto, o status ou valorização social e, por último, a obrigação de escolher.

Do universo dos alunos respondentes, a parte majoritária $(74,55 \%)$ afirma nunca ter frequentado curso ou formação que prepare para alguma atividade ocupacional ou profissional. O contingente de alunos que já participaram de algum curso ou formação ocupacional ou profissional, apontaram que realizaram ou realizam cursos básicos ou técnicos de idiomas, informática, teatro, enfermagem e administração. Desses, $21 \%$ afirma que o curso não tem relação com as escolhas que pretende fazer.

Quando os alunos que já participaram de algum curso ou formação ocupacional ou profissional foram indagados em relação ao motivo de os fazerem, a maioria apontou que estão investindo na preparação para o mercado de trabalho e na melhoria do currículo, alguns afirmaram que gostam e acham interessante e que querem seguir este ramo profissional e outros que o trabalho exigiu que fizessem. Um dos participantes fez uma observação que encontrou o curso por meio de uma procura pessoal, e que não houve auxílio prévio da escola, o que poderia ser importante, na concepção dele, para outros estudantes.

Do universo de estudantes investigados, a grande parte $(72,7 \%)$ afirma nunca ter exercido algum tipo de trabalho remunerado. Entre os que já exerceram ou exercem alguma 
atividade remunerada, $87 \%$ sinalizam que esta não tem relação com as escolhas que pretendem fazer.

No tocante à primeira aspiração para quando concluírem o ensino médio, 45,5\% deseja fazer um curso superior, 34,5\% quer estudar e buscar aprovação em um concurso público e $10,9 \%$ almeja inserir-se no mercado de trabalho. Os estudantes que querem fazer um curso técnico ou terem o seu próprio negócio representam, respectivamente, 5,5\% e 3,6\%.

Quando solicitado que partilhassem se ao longo da educação básica (educação infantil, ensino fundamental e ensino médio) vivenciaram na escola atividades que os preparassem para o processo de escolha da carreira ou profissão, a maioria dos estudantes $(41,8 \%)$ afirmaram que poucas, $29,1 \%$ disseram que nenhuma, $21,8 \%$ apontaram que algumas e 7,3\% disseram que muitas. Os estudantes que já vivenciaram esse tipo de atividades informaram que, geralmente, foram palestras motivacionais, vocacionais ou debates sobre as ocupações, mas com número limitado de profissões.

A maioria dos estudantes $(58,2 \%)$ disseram que ao longo de toda a educação básica nunca realizaram visita técnica ou alguma atividade em universidade ou faculdade. $32,7 \%$ já tiveram essa oportunidade em uma instituição pública, 3,6\% em uma instituição privada e 5,5\% em ambas. Os que já realizaram explicaram que as atividades que participaram referiam-se, precipuamente, a excursões para conhecer o espaço e as atividades acadêmicas.

Após analisar os dados que possibilitaram a apresentação de um esboço geral do perfil dos estudantes em foco, além de outros elementos indicativos das regularidades dos habitus e outros referentes culturais que estão na base de ser estudante do $3^{\circ}$ ano do ensino médio de uma escola de tempo integral da rede pública de ensino do Distrito Federal, inicia-se a discussão sobre as representações sociais construídas pelos educandos sobre a escola, a sua função, a sua relação com a OVP e a escolha de uma carreira ou profissão, por meio da análise dos resultados do segundo instrumento aplicado.

Anunciou-se que esta investigação se fundamenta no modelo proposto por Domingos Sobrinho (2014), que além de investigar elementos da praxiologia bourdiesiana, absorve os pressupostos da TRS de Moscovici na qual as representações sociais são tidas como concepções que tem por finalidade guiar para a ação e orientar condutas por meio da comunicação entre os sujeitos. Guiados pelo modelo mencionado, cujo interesse principal é a captação das regularidades, utiliza-se, para completar a análise, a Teoria do Núcleo Central desenvolvida por Abric (1998).

De acordo com Abric (1998), toda representação organiza-se ao redor de um núcleo central é nele que reside a significação compartilhada coletivamente por um grupo. Através 
dessa abordagem estrutural é possível observar a organização e a hierarquia dos elementos que fundamentam uma representação social. A existência desse núcleo explica o fato das representações sociais serem uma forma de conhecimento elaborado e compartilhado socialmente, elas apontam para uma memória e pensamento social, produzidas historicamente.

Oliveira et. al (2005), seguidores de Abric, ao tratarem sobre a estrutura das representações sociais expõem a composição dos seus elementos destas em quatro quadrantes levando em consideração as frequências e a ordem de evocação das palavras e sendo agrupadas da seguinte forma:

- No quadrante superior esquerdo estão aquelas com maiores frequências e que foram mais prontamente evocadas, elas formam o núcleo central da representação que é a parte mais estável e consensual da representação e é menos sensível a alterações em função do campo social ou de práticas rotineiras dos sujeitos. Neste estudo denomina-se também as evocações desse grupo de "central para muitos".

- O quadrante inferior esquerdo, é a zona de contraste, corresponde àquelas palavras com menores frequência, mas que foram prontamente evocadas. Nesta investigação intitula-se também as palavras evocadas desse grupo de "central para poucos".

- No quadrante superior direito situam-se aquelas que possuem uma alta frequência, entretanto a posição média na ordem de evocação é menor e não é suficiente para integrar o núcleo central da representação, denominando-se primeira periferia. Nesta pesquisa intitula-se também as evocações desse grupo de "periféricas para muitos".

- E por fim, no quadrante inferior direito, a segunda periferia, engloba as evocações mais distantes do núcleo central pois foram enunciadas posteriormente e tiveram menor frequência. Neste estudo denomina-se também as palavras desse grupo de "periféricas para poucos".

Com o intuito de sistematizar e elucidar os quadrantes e tendo como fundamento os estudos de Abric (1998) e Oliveira et. al (2005), que realizam o cruzamento da frequência das evocações com a ordem das evocações, elaborou-se o quadro a seguir: 
Quadro 2 - Quadrantes da estrutura das representações sociais

\begin{tabular}{|c|c|c|}
\hline & \multicolumn{2}{|c|}{$+\leftarrow$ Ordem de Importância $\rightarrow$ - } \\
\hline $\begin{array}{l}+ \\
\uparrow \\
\cdot \frac{\pi}{0}\end{array}$ & $\begin{array}{c}++ \\
\text { Núcleo Central da Representação } \\
\text { Central para muitos }\end{array}$ & $\begin{array}{c}+- \\
\text { Primeira Periferia } \\
\text { Periférico para muitos }\end{array}$ \\
\hline 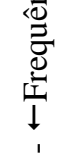 & $\begin{array}{c}+ \\
\text { Zona de Contraste } \\
\text { Central para poucos }\end{array}$ & $\begin{array}{c}-- \\
\text { Segunda Periferia } \\
\text { Periférico para poucos }\end{array}$ \\
\hline
\end{tabular}

Fonte: Elaborado pelo pesquisador (2019).

No TALP, instrumento de coleta de dados, perguntou-se aos estudantes quais eram as três palavras ou expressões que vindas à mente ao lerem "Quanto à função da escola, a escola serve para...”, “A escola é...”, "Quanto a orientação vocacional e profissional, a escola...” e "Escolher uma carreira ou profissão é...". Logo após, solicitou-se que assinalassem a mais importante evocação e a justificativa para a que fosse avaliada como tal.

É importante destacar que alguns TALP foram devolvidos incompletos, nos quais os estudantes não quiseram responder ou apontaram apenas uma palavra ou não justificaram o motivo da escolha da evocação mais importante. Com os resultados dos testes completos e incompletos disponíveis, criou-se um banco de dados em uma planilha eletrônica registrando as evocações de cada estudante colocando inicialmente as que foram apontadas como de maior importância e posteriormente na ordem em que foram lembradas.

A partir dessa planilha pôde-se, de acordo com a técnica de análise de conteúdo proposta por Bardin (1997), realizar a leitura flutuante das evocações e suas justificativas e criar, em seguida, categorias que englobassem palavras ou expressões que tinham aproximação semântica. Por exemplo, quando solicitado que dissessem qual é a função da escola alguns alunos afirmaram que seria "auxiliar”, “ajudar”, "guiar”, "levar a caminhos”, “abrir caminhos”, "abrir portas", "dar um futuro" e "orientar". Ao realizar a análise do conteúdo dessas evocações e suas respectivas justificativas, acredita-se que o vocábulo que poderia comportar todas essas evocações seria "orientar". Assim foi feito com todas as evocações, buscou-se categorizá-las a fim de organizar e agrupar o material produzido, possibilitando interpretações mais consistentes.

Ao finalizar o processo de organização das respostas geradas pelos estudantes, utilizouse como ferramenta de apoio ao processo de investigação das representações sociais, o 
OpenEvoc ${ }^{2}$, um programa online para análise das evocações que oferece funcionalidades de coleta ou importação de dados, processamento e geração de quadros de frequências e ordem das evocações (SANT'ANNA, 2012).

Uma vez que já havia sido criada uma planilha eletrônica com o banco de dados para realizar a leitura flutuante e a categorização das evocações emergidas pelo estudo, importamola para o programa OpenEvoc e extraiu-se deste os quadros de frequências e ordem de evocação gerados automaticamente de cada representação social investigada. Tais quadros distribuem os vocábulos evocados em quatro quadrantes, permitindo a visualização da estrutura da representação e oferece subsídios para a análise.

Além dos quadros, outro elemento que nos auxiliou com a fundamentação da análise são as justificativas da atribuição de maior importância para as palavras ou expressões, obtidas por ocasião do TALP, por meio delas viabilizou-se conhecer com mais detalhes as razões das mesmas e auxiliaram no processo de explicação e análise do conteúdo representacional.

Reconhecendo que as representações sociais são construídas com base nas regularidades de um mesmo habitus, no caso o estudantil, e também que elas se constituem em um meio eficaz para a compreensão de como o habitus é produzido e estruturado, buscou-se fazer inferências explicativas diante das informações anteriormente apresentadas e que foram geradas por meio da análise do questionário socioeconômico e cultural, numa perspectiva dialética que articule as representações sociais e os elementos da praxiologia de Bourdieu, em especial, o habitus.

Para cada representação social investigada, inicia-se com a apresentação do quadro da estrutura da representação social construída pelos estudantes e gerada pelo OpenEvoc e seguese com a discussão sobre os seus significados, buscando identificar a correlação entre as evocações e o habitus dos estudantes, haja vista que na atividade representativa é possível observar "a rede de significações em torno do objeto representado e sua relação com o meio social" (MOSCOVICI, 1978, p. 289).

\section{A representação social sobre a função da escola}

A primeira representação investigada refere-se à função da escola. Solicitou-se que os estudantes completassem a frase indutora "Quanto à função da escola, a escola serve para...”. Abaixo apresenta-se um quadro com a estrutura da representação social, após os resultados do

\footnotetext{
${ }^{2}$ OpenEvoc é um programa gratuito para coleta, análise e processamento de dados de pesquisa na perspectiva estrutural da Teoria das Representações Sociais, desenvolvido e mantido pelo Prof. Dr. Hugo Cristo Sant'Anna da Universidade Federal do Espírito Santo.
} 
TALP terem sido submetidos à análise e organização de conteúdo e serem processados pelo programa OpenEvoc.

Quadro 3 - Estrutura da representação social construída pelos estudantes sobre a função da escola

\begin{tabular}{|c|c|c|c|c|c|}
\hline++ & \multicolumn{2}{|c|}{$\begin{array}{c}\text { Frequência }>=1,23 / \text { Ordem de evocação } \\
<2,41\end{array}$} & +- & \multicolumn{2}{|c|}{$\begin{array}{c}\text { Frequência }>=1,23 / \text { Ordem de evocação } \\
>=2,41\end{array}$} \\
\hline $14,72 \%$ & ensinar & 1,71 & $13,50 \%$ & socializar & 2,41 \\
\hline $12,88 \%$ & aprender & 1,81 & $1,84 \%$ & desenvolver & 3 \\
\hline $9,82 \%$ & educar & 1,75 & $1,23 \%$ & disciplinar & 2,5 \\
\hline $9,20 \%$ & formar & 2,09 & $1,22 \%$ & cuidar & 2,5 \\
\hline $8,59 \%$ & estudar & 1,64 & & & \\
\hline $7,98 \%$ & orientar & 2,08 & & & \\
\hline $7,36 \%$ & preparar & 1,92 & & & \\
\hline $4,91 \%$ & ampliar conhecimento & 1,25 & & & \\
\hline $1,23 \%$ & dar fundamentos & 1 & & & \\
\hline-+ & \multicolumn{2}{|c|}{$\begin{array}{c}\text { Frequência }<1,23 \text { / Ordem de evocação }< \\
2,41\end{array}$} & -- & \multicolumn{2}{|c|}{$\begin{array}{c}\text { Frequência }<1,23 / \text { Ordem de evocação }>= \\
2,41\end{array}$} \\
\hline $0,61 \%$ & criar responsabilidade & 1 & $0,61 \%$ & avaliar & 3 \\
\hline \multirow[t]{6}{*}{$0,61 \%$} & nada & 1 & $0,61 \%$ & alienar & 3 \\
\hline & & & $0,61 \%$ & incentivar & 3 \\
\hline & & & $0,61 \%$ & vivenciar & 3 \\
\hline & & & $0,61 \%$ & dedicar & 3 \\
\hline & & & $0,61 \%$ & ser feliz & 3 \\
\hline & & & $0,61 \%$ & aprender e ensinar & 3 \\
\hline
\end{tabular}

Fonte: Elaborado pelo pesquisador com base nas respostas dos estudantes e com o auxílio do OpenEvoc (2019)

Como pode-se verificar, no quadrante superior esquerdo estão situadas as evocações: “ensinar", “aprender”, “educar", “formar”, “estudar”, “orientar”, “preparar”, “ampliar conhecimento" e "dar fundamentos". A relação entre as evocações do núcleo da representação é recorrente entre os estudantes, que regularmente evocaram uma determinada palavra e na justificativa trouxeram alguma expressão que se articulava a outra evocação.

Para os estudantes investigados, a função da escola de ensinar e educar está intimamente ligada com a de aprender, estudar e ampliar conhecimento. Através das justificativas das evocações identifica-se que os estudantes reconhecem que a escola "ensina coisas que não sabemos" e que "sem a escola não temos novos conhecimentos", ou seja, é através dela que muitos têm acesso a novos conhecimentos que no cotidiano talvez não teriam.

Outras evocações que se relacionam neste núcleo referem-se à função de orientar e preparar. Os estudantes percebem que a escola tem função orientadora e preparatória "para a vida, para o futuro, para o ensino superior" e "para entrar no mercado de trabalho". Em uma justificativa, um estudante adverte "Crianças ou adolescentes que muitas vezes não possuem o auxílio para a vida ou até mesmo para a profissão encontra ou deveria encontrar na escola”. 
O período de escolarização é visto pelos educandos como uma "fase" que estão sendo preparados. Isso nos remete à afirmação de Perrenoud (2013) que afirma que a escolaridade obrigatória não tem ensinado a compreensão das transformações do mundo do trabalho e que a escola deve refletir e entender por quê as pessoas estão tão pouco preparadas para vivenciar essas transformações. Para os estudantes, a escola é vista como uma instituição que "ajuda a guiar", a "abrir caminhos" e a "dar oportunidades de vida", possibilitando que "o aluno sonhe com sua vida profissional”. Convém destacar, que de acordo com o habitus apreendido, a maioria dos estudantes investigados desejam fazer um curso superior ou estudarem e buscarem aprovação em um concurso público.

Ainda na perspectiva preparatória, a escola é vista como um local que "existe para te dar uma boa vida", haja vista que a escola é vista como um espaço para "encaminhar formação para a vida adulta" e "o conhecimento e a educação nos preparam para o futuro" e "pelo conhecimento garantimos um futuro promissor". Tal representação é explicada pelo habitus estudantil de ter pais e mães com profissão/ocupação que, em geral, podem ser classificadas como predominantemente manuais, o que na sociedade brasileira significa estar em posições menos prestigiadas da sociedade e do mundo do trabalho (DOMINGOS SOBRINHO, 1998; 2000) e que provavelmente incutem em seus filhos aspirações por condições de vida e trabalho melhores e veem na educação um sinal de "redenção" para os seus projetos de vida, expressão da dimensão ética do habitus (ethos).

Os educandos também representam a possibilidade de mobilidade social como uma função da escola, ao afirmarem que "é através do aprendizado que se consegue subir nas classes sociais" e que é por meio da escola que se "aprende a entrar em uma boa faculdade, emprego, concurso e ter conhecimento". Em consonância à essa representação, Carnoy e Levin (1987), afirmam que o Estado ampliou a rede escolar respondendo às reivindicações da classe média $\mathrm{e}$ da classe trabalhadora que buscava a mobilidade social para os seus filhos. A escola tornou-se progressivamente um meio de atingir posições profissionais ou ingressar na classe trabalhadora (CARNOY; LEVIN, 1987). Desse modo, o sistema de ensino tornou-se um caminho remanescente para a mobilidade e para a estabilidade, pois a educação tornou-se fundamental para a competição por cargos de status mais elevado. Os estudantes depositam na escola e no ato educativo a importância para garantir um futuro melhor e também atribuem a ela o múnus [função] de "ajudar a escolher o que vamos fazer no futuro".

Formar é uma outra evocação que emergiu para a função da escola e sugere haver compartilhamento de uma representação pautada na modelagem e no desenvolvimento do indivíduo para a sociedade. Os discursos dos estudantes fundamentam essa interpretação ao 
afirmarem que a formação é para "se adaptar a vida", "sermos pessoas melhores", "para nos tornarmos boas pessoas e que entendem das coisas", "passar uma boa impressão", "não sair por aí fazendo besteiras". Tais discursos nos reportam ao mencionado por Saviani (2010), que ao tratar sobre a extensão da escolarização para todos, a escola passou a ter um papel de ser uma agência formadora de sujeitos bem-educados, civilizados, polidos e aptos a viverem na sociedade moderna.

Os educandos também admitem que "existe um conjunto de pessoas que estudaram e se prepararam para ensinar" e que, por isso, é função da escola dar fundamentos e fornecer "uma boa base", que terá repercussões futuras, pois ela "é fundamental e precisamos lá na frente desses fundamentos".

No quadrante inferior esquerdo encontram-se as evocações: "criar responsabilidade" e "nada". Nessa zona o elemento "criar responsabilidade" reforça a evocação "formar" contida no núcleo central, ao associar a função da escola a questão da modelagem de comportamentos. Já o elemento "nada" contrasta com o núcleo central, que apresenta as diversas funções que são percebidas como atribuições da escola.

No quadrante superior direito localizam-se os elementos: "socializar", "desenvolver", “disciplinar" e "cuidar". Os elementos da primeira periferia da estrutura da representação, apontam que a escola é um espaço no qual se "convive com várias pessoas de diferentes tipos e maneiras" e que o convívio social e as relações desenvolvidas nesse ambiente auxiliam no desenvolvimento para a vida.

No quadrante inferior direito estão os elementos: "avaliar", "alienar", "incentivar", "vivenciar", “dedicar", "ser feliz", “aprender e ensinar". Como percebe-se, a rede de significados que se articula em torno do objeto representado é abrangente e diversa. Convém ressaltar que um estudante realizou a evocação "aprender e ensinar" combinada, que no primeiro quadrante foram evocados separadamente e embora não tenham sido evocados de forma combinada, aparecem ligados nas justificativas apresentadas. Preferiu-se deixar a representação combinada e elucidar o motivo de estar disposta na segunda periferia e a presença do seu significado está contido no núcleo central. As demais, que não possuem essa particularidade, tratam-se de evocações com menor frequência e enunciadas posteriormente, portanto distanciam-se do núcleo central da representação (OLIVEIRA et al., 2005).

A análise do conteúdo representacional sobre a função da escola permite reforçar a hipótese, explicitada no modelo teórico, segundo a qual a representação social é não só uma via de acesso às estruturas e esquemas do habitus que a produz, mas também uma via de acesso à compreensão de como o poder simbólico atua impondo legitimidades ou naturalizando os 
sentidos dos objetos do mundo social. Percebe-se, no tocante à função da escola, a existência de um consenso quanto ao seu papel de orientar, ensinar, educar, formar, dentre outros. Resultado que aparece tanto no quadrante onde se supõe estar a centralidade da estrutura da representação pesquisada, quanto na primeira e segunda periferias.

Todavia, duas evocações destoam desse consenso, "nada" e "alienar", parecendo indicar uma quebra do mesmo entre os sujeitos pesquisados. Uma outra associação também destoa, mas em sentido diferente: "ser feliz". Nesse sentido, enquanto "nada" e "alienar" parecem indicar uma quebra na incorporação do sentido hegemônico de escola, o qual leva a naturalizar a função dessa instituição (pois, nem sempre, ou nunca, o prometido pelos discursos oficiais e os próprios agentes do campo educacional, como professores e outras categorias implicadas, se traduz em realidade), "ser feliz" tem muito mais a ver com a polifasia cognitiva presente na construção das representações sociais.

O fenômeno da polifasia cognitiva expressa-se pela heterogeneidade das evocações, inerente à construção das representações sociais. A polifasia cognitiva presente no senso comum é resultante da fusão das diferentes fontes de saberes e informações que os indivíduos utilizam para a sua construção. Como afirma Moscovici, “as pessoas não são monofásicas e expressam uma única forma de pensamento [...], a diversidade de formas de pensamento, é a regra, e não a exceção" (MOSCOVICI, 2009, p. 328-329).

\section{A representação social sobre a escola}

A segunda representação social que se investiga trata-se da escola. Pediu-se que os educandos completassem a frase indutora “A escola é...”. É conveniente destacar, que no momento da aplicação do TALP, o pesquisador explicou que escola nesse teste não se referia unicamente a unidade escolar que eles atualmente estudam, mas às instituições escolares de uma forma geral. A seguir expõe-se um quadro com a estrutura da representação social, após os resultados do TALP terem sido submetidos à análise e organização de conteúdo e serem processados pelo programa OpenEvoc. 
Quadro 4 - Estrutura da representação social construída pelos estudantes sobre a escola

\begin{tabular}{|c|c|c|c|c|c|}
\hline++ & \multicolumn{2}{|c|}{$\begin{array}{c}\text { Frequência }>=1,82 / \text { Ordem de evocação } \\
<2\end{array}$} & +- & \multicolumn{2}{|c|}{$\begin{array}{c}\text { Frequência }>=1,82 / \text { Ordem de evocação } \\
>=2\end{array}$} \\
\hline $21,82 \%$ & importante & 1,78 & $15,76 \%$ & cansativa & 2,15 \\
\hline $10,30 \%$ & ambiente de aprendizado & 1,82 & $13,94 \%$ & Boa & 2,09 \\
\hline $4,85 \%$ & preparatória & 1,75 & $4,25 \%$ & acolhedora & 2,09 \\
\hline $3,03 \%$ & rígida & 1,8 & $3,03 \%$ & ruim & 2,2 \\
\hline $2,42 \%$ & mais ou menos & 1 & $2,42 \%$ & pública & 2 \\
\hline $1,82 \%$ & eficiente & 1,67 & $2,42 \%$ & ambiente para socialização & 2,5 \\
\hline & & & $2,42 \%$ & interessante & 2,5 \\
\hline & & & $2,42 \%$ & difícil & 2,5 \\
\hline & & & $1,82 \%$ & experiência & 2,33 \\
\hline-+ & \multicolumn{2}{|c|}{$\begin{array}{l}\text { Frequência }<1,82 \text { / Ordem de evocação }< \\
2\end{array}$} & -- & \multicolumn{2}{|c|}{$\begin{array}{c}\text { Frequência }<1,82 \text { / Ordem de evocação }>= \\
2\end{array}$} \\
\hline $1,21 \%$ & obrigatória & 1 & $0,61 \%$ & inteligente & 2 \\
\hline $0,61 \%$ & dispensável & 1 & $0,61 \%$ & uma sede de problemas sociais & 2 \\
\hline $0,61 \%$ & um direito & 1 & $0,61 \%$ & campo de futebol & 3 \\
\hline $0,61 \%$ & um instrumento de escravização & 1 & $0,61 \%$ & fraca & 3 \\
\hline $0,61 \%$ & esquecida & 1 & $0,61 \%$ & ambiente qualquer & 3 \\
\hline $0,61 \%$ & indescritível & 1 & & & \\
\hline
\end{tabular}

Fonte: Elaborado pelo pesquisador com base nas respostas dos estudantes e com o auxílio do OpenEvoc (2019)

Como pode-se identificar, aqueles elementos prontamente evocados e com maior frequência foram: "importante", "ambiente de aprendizado", "preparatória”, "rígida", "mais ou menos" e "eficiente". Os elementos do núcleo central diretamente estão conectados e pôde-se realizar essa constatação pelas justificativas apresentadas pelos educandos.

A escola é vista, pelos estudantes, como um importante ambiente de aprendizado que prepara os estudantes de forma eficiente. A escola ser importante exprime ideias associadas à contribuição que ela viabiliza aos estudantes, ela é percebida como "base, infraestrutura e suporte”. Convém salientar que muitos estudantes também enfatizam o alcance global da escola ao afirmarem que "todos devem seguir esse caminho" e que "todos precisam de um ensino bom na escola", considerando-se que a maioria dos estudantes estudaram toda da educação básica em escolas públicas, tais discursos reforçam a importância da escola, como um mecanismo que as famílias e os próprios estudantes utilizam para se prepararem para os desafios da vida.

A escola ser vista como importante e preparatória enfatiza o núcleo da representação social que fora analisada anteriormente, a função da escola. É nesse ambiente de aprendizado que se constitui a "base para a vida", "para o futuro bom ou melhor", "para a faculdade" e "para o mercado de trabalho". A escola é vista como "recompensadora" e "sinônimo de possibilidade", "pois ajuda a pensar no que você vai querer para a sua vida". 
Destaca-se também que a escola é concebida como a "segunda base para a vida, pois a primeira é dos pais". Admiravelmente, os estudantes afirmam que "passamos mais tempo na escola com nossos professores e colegas do que com a nossa família, e nesse tempo obtemos conhecimento, sejam bons ou ruins". Embora passem a maior parte do tempo na escola, paradoxalmente, este é o local percebido como o que com menor frequência é fonte de informação profissional. Consequentemente, esse fato tem reflexo na ordem de importância na influência na OVP, colocando a família e outros aspectos a frente da escola.

O elemento "eficiência" da representação social da escola é expresso na intencionalidade de afirmar que a escola é produtiva e "especializada em tornar pessoas melhores e com mais conhecimentos".

A concepção "rígida" e "mais ou menos" para a escola emergiu entre os estudantes e as justificativas apresentadas pelos estudantes, ajudaram a desvelar ao motivo dessa representação. Os estudantes afirmam que a escola "às vezes parece uma cadeia com regras que muitas vezes não têm necessidade", afirmam não gostar do tempo integral e também apontam a necessidade de "ter mais projetos inovadores e conquistar os alunos com algo bom". Um estudante chega a afirmar que "nunca fui fã de escola, dias raros que tive grande interesse de ir à escola".

Os elementos logo evocados, porém, com baixa frequência são: "obrigatória", “dispensável”, "um direito", "um instrumento de escravização", “esquecida” e "indescritível”. Nesse agrupamento de contraste, há elementos que reforçam o núcleo central: "obrigatória” e "um direito" ao afirmarem que "todos têm que ter a oportunidade de estudar" e que "o conhecimento deve estar aberto e disponível como direito de qualquer cidadão, pois o saber é libertador". Emergiu também a seguinte afirmação "Dizem que se você não estuda você não vai ser ninguém", neste discurso, há clareza quanto a obrigatoriedade de a escola ser uma prescrição se para ter um futuro bom, entretanto, ao afirmar "dizem que..." o estudante reproduz um discurso de terceiros.

Essa afirmação alude para a relação do habitus com a cultura hegemônica, trata-se de uma apreensão particular do grupo sobre a cultura legítima. Os estudantes agem sobre um mundo já informado por formas dominantes e, a partir delas e das suas experiências passadas e presentes, constroem as ressignificações do mesmo. Tratam-se de relações de força que influenciam na construção dos sentidos dos objetos do mundo social. O discurso hegemônico impõe o seu arbitrário como algo inquestionável e natural (DOMINGOS SOBRINHO, 2014).

O conteúdo representacional "esquecida" é justificado como a escola sendo um local de formação de novos cidadãos e pessoas melhores, “mas é o lugar que mais se esquecem ou fazem 
de qualquer jeito". A evocação "indescritível” denota dificuldade de os estudantes expressarem a concepção de escola. Os demais, quais sejam, "dispensável” e "um instrumento de escravização", contrastem com os demais conteúdos, o que nos leva a considerar haver um subgrupo com representação diferente e que acredita que "não há necessidade de aprender o que a escola ensina fora de casa".

Os elementos com maior frequência e tardiamente evocados constituem: "cansativa", "boa", "acolhedora", "ruim", "pública”, "ambiente para socialização", “interessante”, "difícil” e "experiência”. As evocações "cansativa", "ruim”, "difícil” são conteúdos de sentido negativo e estão relacionadas, de acordo com as explicações dos estudantes, com o volume de estudos, com o tempo integral e com a pressão no que tange aos vestibulares. Excertos a seguir exprimem o estresse relacionado à essas questões: "às vezes nos dão muito conteúdo ou informações, ou pressionam muito em questão de vestibulares" e "alguns dias da semana nós ficamos 10 horas seguidas na escola" o que "[...] deixa os alunos cansados".

As evocações "interessante" e "boa" sugerem existir o compartilhamento de uma representação de escola pautada em um espaço positivo no qual "aprendemos várias coisas interessantes e curiosas", momentos passíveis também de diversão. Os elementos "acolhedora" e "pública" reforçam a ideia de que a escola é uma instituição destinada a "acolher o aluno e a família para contribuir para uma sociedade melhor", inclusive a ela é atribuída títulos que demonstram a afetividade da relação, como por exemplo ser vista como "segunda casa" e "segunda família". Os demais conteúdos representacionais desse quadrante, "ambiente para socialização" e "experiência", sinalizam a escola ser um lócus que se vivencia e lida com as diferenças.

As evocações mais tardias e menos frequentes são "inteligente", "uma sede de problemas sociais", "campo de futebol", "fraca" e "ambiente qualquer". Essas evocações compõem a segunda periferia que possuem como características a questão da mutabilidade e flexibilidade, indicando a expressão individualizada das representações sociais (OLIVEIRA et al., 2005).

A análise do sentido atribuído à escola, assim como a análise da função da escola, também possibilita reforçar a hipótese que representação social é não só uma via de acesso às estruturas e esquemas do habitus que a produz, mas também uma via de acesso à compreensão de como o poder simbólico atua impondo legitimidades ou naturalizando os sentidos dos objetos do mundo social. Os conteúdos sobre a função e o sentido da escola não são excludentes, mas recortes na apreensão do significado da instituição escolar no contexto cultural pesquisado. Essa apreensão em separado das representações sociais dos dois objetos, resulta num achado 
relevante: ao confrontar os resultados da análise da estruturação dos conteúdos referentes à função da escola e representações sociais da escola, percebe-se que o consenso existente no primeiro caso, quase desaparece no segundo.

Observe-se que, em todos os quadrantes relativos à estruturação do conteúdo das representações sociais da escola, há elementos que destoam do sentido predominante (rígida, mais ou menos, cansativa, ruim...). Diante disso, é possível destacar que a incorporação da naturalização do sentido de escola como "importante", "ambiente de aprendizado", "preparatória" e que sem estudar "você não será ninguém" tem sido uma constatação em muitas pesquisas, não só em representações sociais, principalmente quando se trata de populações de trabalhadores classificados como manuais, posto que, para essas, a escola é vista como redentora e único caminho para a melhoria de vida. Assim, o conteúdo representacional e a posição ocupada pelos estudantes no espaço social relacionam-se diretamente.

Há que se destacar que a dissonância encontrada em meio ao consenso predominante quanto ao sentido atribuído ao objeto simbólico "escola", aponta claramente a existência de uma tensão semântica na estruturação do conteúdo, que pode estar indicando tanto uma evidência de transformação da representação social hegemónica (portanto, ainda em curso) quanto a existência de uma outra representação social da escola - para sanar esta dúvida seria necessário uma análise mais aprofundada do material coletado e a utilização de métodos auxiliares, o que ultrapassaria os limites dessa dissertação.

\section{A representação social sobre o posicionamento da escola em relação à OVP}

A terceira representação que se perscruta refere-se ao posicionamento da escola em relação à OVP. Solicitou-se que os estudantes completassem a frase indutora "Quanto à orientação vocacional e profissional, a escola...”. Convém apontar, que durante a aplicação do TALP, o pesquisador frisou que escola nesse teste não se referia unicamente a unidade escolar que eles atualmente estudam, mas às instituições escolares de uma forma geral. Adiante exibese um quadro com a estrutura da representação social, após os resultados do TALP terem sido submetidos à análise e organização de conteúdo e serem processados pelo programa OpenEvoc. 
Quadro 5 - Estrutura da representação social construída pelos estudantes sobre a relação da escola e a OVP

\begin{tabular}{|c|c|c|c|c|c|}
\hline \multirow{3}{*}{\begin{tabular}{|r|}
++ \\
$7,52 \%$ \\
\end{tabular}} & \multirow{2}{*}{\multicolumn{2}{|c|}{$\begin{array}{c}\text { Frequência }>=1,5 / \text { Ordem de evocação }<\mid \\
1,84\end{array}$}} & \multirow{3}{*}{$\begin{array}{c}+- \\
+38,35 \% \\
\end{array}$} & \multirow{2}{*}{\multicolumn{2}{|c|}{$\begin{array}{c}\text { Frequência }>=1,5 / \text { Ordem de evocação }>= \\
1,84\end{array}$}} \\
\hline & & & & & \\
\hline & precisa ajudar & 1,7 & & não auxilia & 1,88 \\
\hline $4,51 \%$ & regular & 1,83 & $27,82 \%$ & ajuda & 1,84 \\
\hline $3,76 \%$ & capacitada & 1,2 & $4,51 \%$ & ruim & 2,5 \\
\hline $3,01 \%$ & boa & 1,5 & $1,50 \%$ & essencial & 2 \\
\hline $3,01 \%$ & prepara & 1,75 & & & \\
\hline $1,50 \%$ & seleciona & 1 & & & \\
\hline-+ & \multicolumn{2}{|c|}{$\begin{array}{c}\text { Frequência }<1,5 / \text { Ordem de evocação }< \\
1,84 \\
\end{array}$} & -- & \multicolumn{2}{|c|}{$\begin{array}{c}\text { Frequência }<1,5 / \text { Ordem de evocação }>= \\
1,84\end{array}$} \\
\hline $0,75 \%$ & molda & 1 & $0,75 \%$ & comunicativa & 2 \\
\hline \multirow[t]{3}{*}{$0,75 \%$} & melhorando & 1 & $0,75 \%$ & conquistas & 2 \\
\hline & & & $0,75 \%$ & rígida & 3 \\
\hline & & & $0,75 \%$ & chata & 3 \\
\hline
\end{tabular}

Fonte: Elaborado pelo pesquisador com base nas respostas dos estudantes e com o auxílio do OpenEvoc (2019)

Como pode-se visualizar, no núcleo central da representação estão situadas as evocações: "precisa ajudar", "regular”, “capacitada", "boa”, “prepara” e "seleciona”. Para os estudantes, quanto à OVP, a escola "precisa ajudar". Nos enunciados pelos estudantes, ela precisa "tratar como assunto acadêmico" e "precisa ajudar a pessoa a decidir o que ela quer ser dando várias opções e oportunidades”. Nesse sentido, Ferretti (1992) sugere que a OVP atue predominantemente através do currículo, pois dirige-se a um expressivo número de assistidos, abrangendo-se a todos, os que escolhem com mais ou menos restrições, considerando a questão da audiência pública e obrigatória.

Emergiu também a justificativa dos estudantes de que "uma boa escolha de um futuro emprego, sendo fruto de um assunto tratado nas escolas, incentiva o aluno a evitar a evasão escolar". Além de tornar a escola mais interessante e motivadora, por articular o conhecimento com a vida e o futuro, o trabalho com OVP poderia minimizar a ocorrência dos percursos com escolhas questionáveis evidenciados pelo estudo realizado por Zago (2006), que aponta para os altos índices de evasão universitária, a troca de cursos e a auto exclusão do acesso à universidade pública.

Outra evocação que se encontra no núcleo da estrutura da representação social em questão é "regular". Os estudantes atribuem que a escola é mediana em relação à OVP, porque “não dão a devida atenção", "não nos prepara bem", "aborda de forma superficial”, "para umas pessoas até ajuda, e outras como eu, não". Inclusive sentem faltam de uma sistematização, ao afirmarem que "não tratam desse assunto de uma forma certa". Tal constatação reforça o pensamento de Levenfus (2002) de que a falta de obrigatoriedade curricular da OVP deixa o jovem completamente sozinho defronte um dilema que decidirá seu futuro. 
Os alunos admitem que a escola é "boa" e "capacitada", atestam que tem "ótimos professores" e que "sabem dar uma boa aula", elogiam também a atuação da uma psicóloga escolar.

Os estudantes também apontam que a escola "prepara" "para o futuro", para "obter bons empregos" e que embora preparem também para o Exame Nacional do Ensino Médio (ENEM) "não conversam ou orientam sobre as profissões".

Outro conteúdo representacional do núcleo é que a concepção de que a escola "seleciona" emergiu a justificativa de que ela "seleciona e mostra uma concorrência na qual quem estuda ganha mais" e que também ela "nos ajuda a entender melhor e nos ensina a querer o melhor". Nesse sentido, verifica-se a expressão da dimensão cognitiva do habitus (eidos), na qual os estudantes antecipam o futuro, buscam calcular as suas possibilidades e consideram que na nova dinâmica social o jogo de conflitos está no direito de programar o futuro, o próprio e o dos outros (DE MASI, 1999). Assim, os esquemas do habitus funcionam como orientadores práticos, viabilizando aos estudantes sentirem e pressentirem quais as probabilidades de construírem seus projetos de vida e que ocupações/profissões seriam mais ajustadas às suas possibilidades diante das condições objetivas.

Na zona de contraste encontram-se as evocações "molda" e "melhorando". Denotandose que a escola impacta na formação do estudante enquanto futuro profissional e que esse processo tem avançado.

$\mathrm{Na}$ primeira periferia localizam-se os elementos "não auxilia", "ajuda", "ruim" e "essencial". Realizando uma análise geral, verifica-se que "não auxilia" e "ajuda" foram palavras com alta frequência de evocação, por sinal as maiores de todas, e apesar da ordem média de evocações não terem sido suficientes para integrá-las ao núcleo esses dois elementos têm tendência à centralidade. Essa hipótese é reforçada pelas justificativas dadas para a importância de outras evocações e que indiretamente afirmam que a escola "não auxilia" ou "ajuda" nesse processo. Paradoxalmente, os estudantes afirmam que a escola "não auxilia" e "ajuda" na OVP.

A análise das justificativas da evocação "não auxilia" foi realizada combinadamente com as da evocação "ruim", pois não se dissociam. Os estudantes afirmam que há "falta de dedicação" da escola nesse sentido, que "só jogam os conteúdos" e "não presta serviços em relação à isso". Tal inexistência é vista como um abandono, pois denota que a escola "não se importa com os alunos" em decorrência disso, restringe-se a fonte de informações profissionais o que pode ser observado no discurso "a maioria das vezes nos interessamos por algo por 
influência familiar". Reitera-se, dessa forma, a informação obtida pelo questionário de que em relação à frequência de diálogo familiar sobre carreira e profissões é maior do que na escola.

Realizou-se a análise das justificativas da evocação "ajuda" em combinação com as da evocação "essencial", haja vista que estão relacionadas. Os estudantes percebem a escola como essencial para a OVP e ajuda pois, oferece base de vida, auxilia a seguir o seu objetivo, a trilhar um determinado caminho e a pensar no futuro. E ela ajuda "ter compromisso com os estudos" e "ter compromisso para podermos ser ótimos trabalhadores".

A escola é percebida pelos estudantes como fonte de informações profissionais, pois "oferece palestras", "ajuda a montar o currículo", e "acabamos convivendo com as matérias e se nos interessar a gente acaba tirando dúvidas". A sua relevância é expressa ao afirmarem que tal orientação é fundamental "pois, se não tiver muitas vezes os alunos escolhem um curso só pelo dinheiro e se tornam profissionais frustrados". Cabe evidenciar que para alguns a escola é vista como o único meio de OVP, o que pode ser percebido na afirmação "sem a escola não sabemos nada sobre orientação". É intrigante esta declaração, pois com o acesso às novas tecnologias, os sujeitos das escolhas, majoritariamente estão conectados e tem muitas possibilidades de acesso à informação, mas, Levenfus (2002) ajuda a deslindar essa questão ao afirmar que embora tenham essas possibilidades de acesso à informação, em contrapartida eles não têm maturidade para selecioná-las criticamente, demandando-se formação para tanto.

É contraditório afirmar que a escola ao passo que ajuda, não auxilia. Um aspecto apreendido do habitus ajuda-nos a esclarecer o paradoxo ajuda e não auxilia, a maioria dos estudantes afirmam que a escola raramente, às vezes ou nunca costuma realizar atividades e conversar com eles sobre carreiras e profissões. Algumas justificativas dos educandos também nos ajudam a elucidar esse imbróglio: "apesar deles tentarem nos ajudar quanto a isso mesmo assim muitos têm dúvidas" e "quando abordam o tema, não trabalham todas as profissões".

$\mathrm{Na}$ segunda periferia estão os elementos: "comunicativa", "conquistas", "rígida" e "chata”. São conteúdos representacionais evocados com menor frequência e mais tardiamente, portanto afastam-se do núcleo central da representação (OLIVEIRA et al., 2005).

\section{A representação social sobre o processo de escolha de uma carreira ou profissão}

A última representação social que se examina trata-se da percepção do processo de escolha de uma carreira ou profissão. Solicitou-se que os estudantes completassem a frase indutora "Escolher uma carreira ou profissão é...". Abaixo apresenta-se um quadro com a estrutura da representação social, após os resultados do TALP terem sido submetidos à análise e organização de conteúdo e serem processados pelo programa OpenEvoc. 
Quadro 6 - Estrutura da representação social construída pelos estudantes sobre o processo de escolha de uma carreira ou profissão

\begin{tabular}{|c|c|c|c|c|c|}
\hline++ & \multicolumn{2}{|c|}{$\begin{array}{c}\text { Frequência }>=1,5 / \text { Ordem de evocação } \\
<2\end{array}$} & +- & \multicolumn{2}{|c|}{$\begin{array}{c}\text { Frequência }>=1,5 / \text { Ordem de evocação } \\
>=2\end{array}$} \\
\hline $33.33 \%$ & importante & 1.63 & $7.25 \%$ & obrigação & 2.2 \\
\hline $18.12 \%$ & difícil & 1.8 & $5.8 \%$ & bom & 2.25 \\
\hline $10.87 \%$ & pensar no futuro & 1.73 & $3.62 \%$ & decisivo & 2.2 \\
\hline $7.25 \%$ & estressante & 1.8 & $1.45 \%$ & desnecessário & 2.5 \\
\hline $2.9 \%$ & dinheiro & 1.5 & $1.45 \%$ & produtivo & 2.5 \\
\hline-+ & \multicolumn{2}{|c|}{$\begin{array}{c}\text { Frequência }<1,5 \text { / Ordem de evocação }< \\
2\end{array}$} & -- & \multicolumn{2}{|c|}{$\begin{array}{c}\text { Frequência }<1,5 / \text { Ordem de evocação }>= \\
2\end{array}$} \\
\hline $0.72 \%$ & desistir & 1 & $0.72 \%$ & status & 2 \\
\hline \multirow[t]{8}{*}{$0.72 \%$} & fácil & 1 & $0.72 \%$ & opcional & 2 \\
\hline & & & $0.72 \%$ & faz parte da vida & 2 \\
\hline & & & $0.72 \%$ & desejo & 2 \\
\hline & & & $0.72 \%$ & amadurecer & 3 \\
\hline & & & $0.72 \%$ & excepcional & 3 \\
\hline & & & $0.72 \%$ & competência & 3 \\
\hline & & & $0.72 \%$ & investir & 3 \\
\hline & & & $0.72 \%$ & fazer faculdade & 3 \\
\hline
\end{tabular}

Fonte: Elaborado pelo pesquisador com base nas respostas dos estudantes e com o auxílio do OpenEvoc (2019)

Como pode-se verificar, no quadrante "central para muitos" estão situadas as evocações: “importante”, “difícil”, “pensar no futuro", “estressante” e "dinheiro". O processo de escolha de uma carreira ou profissão é visto pelos estudantes como sendo "importante" e significa "pensar no futuro", e alguns argumentos apresentados explicam que é "essencial para ter um propósito de vida", que "temos que fazer algo da vida", que esse processo é importante "para ser alguém na vida" e que é "essencial para a felicidade". Destacam também que é "criar possibilidades" e que é necessário pensar e trabalhar muito essa decisão "para que você escolha realmente o que gosta e também para que seja uma pessoa realizada profissionalmente". É significativo destacar que na caracterização do habitus estudantil, encontrou-se que o principal fator que mais os influenciarão no momento da escolha de uma profissão ou carreira é a possibilidade de autorrealização através do trabalho.

Outros conteúdos do núcleo representacional do processo de escolha de uma carreira e profissão é que ele é visto como sendo uma atividade "difícil" e "estressante". As razões dadas para essa associação têm relação com a pressão que os estudantes afirmam sentir "há muita pressão em relação a escolha de sua profissão, já que o emprego é a base da independência e isso tudo é desgastante em questões pessoais". Tal declaração vão ao encontro do enunciado por Ehrlich, Castro e Soares (2000) que afirmam que a escolha de uma profissão não significa apenas optar por um fazer, mas por um ser, e esse é o motivo do indivíduo experimentar a angústia. 
Os estudantes também dizem se sentirem confusos, pois "temos várias opções mas temos medo de errar" ou de "se arrepender". Outro fator de estresse refere-se ao fato de que "muitas vezes você não passa no curso que você quer e tem que entrar em outro". A complexidade do processo de escolha também é apontada como sendo "muito importante, mas pela falta de instruções ou conselhos se torna difícil e é onde erramos", a falta de orientação faz com que o aluno fique "em dúvida sobre o mercado de trabalho e se é o que quer realmente". O fato é que se vive em um sistema que exige decisões assertivas, mas não proporciona uma educação que possibilite a construção de escolhas realistas e conscientes no que tange à profissão/ocupação e que o serviço de OVP é capaz de ajudar os indivíduos a analisarem os determinantes de suas escolhas e decisões, e desse contexto analisarem sua situação, e construírem o seu projeto de vida (CARVALHO, 2014).

As justificativas dos estudantes também corroboram com a lista elencada por Ferretti (1992) de aspectos que dificultam a realização das escolhas: o desconhecimento de si próprio; o desconhecimento das profissões que existem (o que se exige e também as informações sobre o mercado de trabalho); a incapacidade de obter informações ou de utilizar as disponíveis; a dificuldade para decidir-se entre profissões que demonstram-se igualmente atraentes; a dificuldade para identificar profissões percebidas como adequadas a si, às expectativas da família ou de outras pessoas ou grupos importantes para o indivíduo; a dificuldade para conciliar os diferentes fatores que afetam a escolha.

A associação de "difícil" e "estressante" com o processo de escolha de uma carreira ou profissão foi feita por ocasião das justificativas das evocações mais importantes ao considerarem que é uma "decisão do aluno", que "é uma escolha que vai afetar toda a sua vida" e que "talvez seja algo definitivo". Portanto, também associam que se deve ponderar se é uma carreira que gostam.

Convém salientar que muitos estudantes enfatizam o "dinheiro" como sendo um conteúdo representacional para o processo de escolha de uma carreira ou profissão. Nas explicações afirmam que "precisa de dinheiro" e que "sem uma carreira profissional não temos uma renda para ajudar a família" e destacam também a necessidade de "olhar para o futuro com olhar de lucro". Nesse sentido, a OVP é um serviço que ajuda os indivíduos a lidarem com a dualidade sobrevivência/desejo (CARVALHO, 2014) e mesmo o homem trabalhando para viver pode obter prazer nas atividades produtivas (LEVENFUS, 2002).

No quadrante "central para poucos" encontram-se as evocações: "desistir" e "fácil". Elementos que contrastam com os conteúdos do núcleo central. As justificativas apontadas afirmam escolher uma carreira ou profissão é "desistir", pois significa "abandonar sonhos e 
expectativas". Há também quem afirme que esse processo de escolha é "fácil” e ainda alega que "a escola nunca me influenciou na minha escolha".

No quadrante "periférico para muitos" localizam-se os elementos: “obrigação", "bom”, “decisivo", "desnecessário" e "produtivo". A evocação “obrigação" e "decisivo" sinalizam reforço ao elemento "importante" que está no núcleo dessa representação social, ao reconhecerem que é uma "decisão importante na vida" e que é obrigatória, mas nas justificativas também indicam que muitas vezes significa "escolher de última hora". O último discurso nos reporta ao defendido por Carvalho (2014) de que o imediatismo e a superficialidade da decisão do que fazer após o final do ensino médio é um imbróglio, podendo causar sofrimento, desgaste e frustração, pois essa tomada de decisão na maioria das vezes não foi construída e consolidada ao longo de sua trajetória escolar.

Para os conteúdos representacionais "bom" e "produtivo" os estudantes associam que é o momento em que "você vai decidir o que você será na vida", mas fazem uma crítica "o integral só deixa a gente sonhar, enquanto poderíamos estar em nossos cursos ou trabalhando estamos perdendo tempo aqui dentro". Ademais, há quem defenda ser "desnecessário" o processo de escolha de uma carreira ou profissão.

No quadrante "periférico para poucos" estão os elementos: "status", “opcional”, "faz parte da vida", “desejo", “amadurecer", “excepcional”, “competência”, “investir" e "fazer faculdade". Concernem a evocações mais tardias e de menor frequência, elas são mutáveis, flexíveis e indicam a expressão individualizada das representações sociais (OLIVEIRA et al., 2005).

Assim, discorreu-se sobre as representações sociais sobre a escola, a sua função, a sua relação com a OVP e a escolha de uma carreira ou profissão, em busca de uma confluência com o habitus estudantil. É imperioso salientar que consenso não significa unanimidade. Destarte, as representações sociais são consensuais, mas possuem diferenças interindividuais, como destaca Abric (1998). As representações têm a função típica de contribuir para os processos de formação de condutas e de orientação das comunicações sociais (MOSCOVICI, 1978). Nesse sentido, acredita-se que a Educação para a Carreira é um serviço educacional que tem os atributos para responder adequadamente às necessidades dos sistemas de ensino ao contribuírem para ampliar as representações sociais dos estudantes e para prepará-los para a realização de escolhas e tomada de decisões em seu Projeto de Vida.

Abaixo elaborou-se uma síntese, destacando os principais achados relativos às representações sociais identificadas e correlacionando-os com os pressupostos da Educação para a Carreira. 
No núcleo da representação social dos estudantes sobre a função da escola encontra-se a incumbência de orientar e preparar para a vida, para o futuro, para o ensino superior e para o mundo do trabalho. Salienta-se a pertinência da Educação para a Carreira para o cumprimento dessa função, sendo ela um esforço integral, da educação e da sociedade, direcionado a ajudar os indivíduos a se familiarizarem com os valores de uma sociedade orientada para o trabalho, a integrar estes valores em seus sistemas de valores pessoais e implementar esses valores em suas vidas a fim de que o trabalho seja possível, significativo e satisfatório para cada indivíduo (HOYT, 2005).

Os estudantes concebem que a escola contribui para a garantia de um futuro melhor e elencam como uma de suas competências ajudá-los a escolherem o que farão no futuro. Nesse sentido, a Educação para a Carreira pode ir ao encontro dessa e de outras necessidades dos estudantes, como começar a preocupar-se com o futuro; aumentar gradativamente o controle de sua vida; convencer-se da importância das atividades escolares e de trabalho; adquirir habilidades e atitudes de trabalho, entre outros (MUNHOZ, MELO-SILVA e AUDIBERT, 2016).

Quanto à escola, no cerne da representação social que os estudantes formulam, encontram-se evocações que a instituição escolar é rígida, com muitas regras desnecessárias e que geram o desinteresse. É pertinente relembrar que o movimento da Educação para a Carreira surge diante de um cenário parecido com este e que reclamava reformas educacionais, pois existia o distanciamento entre a educação e a vida profissional (RODRÍGUEZ; CARMONA, 1995). Os estudantes sentiam-se desmotivados e desinteressados, pois não percebiam a relação entre a escola e o mundo exterior.

No que tange à relação da escola com a OVP, no núcleo da estrutura da representação social, os estudantes reconhecem a necessidade da escola precisa auxiliar nesse processo de forma sistemática. A Educação para a Carreira vai ao encontro dessa necessidade apontada pelos estudantes, pois vincula o desenvolvimento vocacional e profissional ao processo de ensino-aprendizagem através do currículo (CARVALHO, 2014).

Os alunos reconhecem que os profissionais da educação são capacitados e que podem contribuir com a OVP se ela deixar de ser uma questão marginalizada. Nessa lógica, o aproveitamento dos profissionais da educação na Educação para a Carreira é um diferencial em relação às demais abordagens de OVP, pois ela se constitui em uma abordagem escolar que integra organicamente o processo de ensino-aprendizagem e o processo de desenvolvimento vocacional requerendo o protagonismo dos profissionais de ensino (CARVALHO, 2014). 
Mundialmente, a rejeição dos professores da absorção de mais essa atividade, por não se sentirem preparados ou por sentirem-se sobrecarregados, constitui-se em um obstáculo recorrente na implantação de programas de Educação para a Carreira. Entretanto, Carvalho (2014) afirma que no contexto educacional brasileiro é possível superar esse obstáculo por causa da presença do pedagogo. A Resolução CNE/CP n ${ }^{\circ}$ 1, de 15 de maio de 2006, que institui as Diretrizes Curriculares para o Curso de Graduação - Licenciatura em Pedagogia, declara que o Pedagogo é um profissional da educação cuja atuação engloba as ações docentes em quaisquer projetos e programas educacionais.

Outro aspecto que cabe ressaltar é que os estudantes relacionam que a escola prepara para o futuro e para vestibulares, mas deixam a desejar quanto à discussões e orientações sobre as ocupações. Essa concepção relaciona-se a uma circunstância elencada por Hoyt (1975) como sendo necessária para o desenvolvimento da Educação para a Carreira: a organização da educação tem atendido melhor as necessidades da minoria dos estudantes que chegariam a serem universitários, enfatizando o nível superior e deixando em segundo plano os projetos de vida daqueles que nunca seriam universitários.

Ainda no que diz respeito à relação da escola com a OVP, na zona de contraste, os alunos representam o ato de "moldar" significando que a instituição forja o estudante enquanto futuro cidadão e profissional. Nesse sentido, Hoyt (2005) elenca algumas competências básicas que são desenvolvidas na Educação para a Carreira e que podem ir ao encontro dessa necessidade formativa dos estudantes: as habilidades acadêmicas básicas; bons hábitos de estudo; o desenvolvimento e a utilização de um conjunto de valores de trabalho; o conhecimento de si mesmo e conhecimento das oportunidades educativas e profissionais disponíveis e habilidades para tomar decisões na carreira. King (2007 apud MUNHOZ; MELO-SILVA, 2011) também sugere responsabilidade, consciência de carreira, pontualidade, habilidade de ouvir e prestar atenção, saber se avaliar e aprender com os erros devem ser desenvolvidos tanto para a aprendizagem escolar como para o futuro desempenho na profissão como temas para serem trabalhados na Educação para a Carreira.

Na primeira periferia, mas com tendência à centralidade, os alunos afirmam que a escola não auxilia e, contraditoriamente, ajuda no processo de OVP. Ajuda, pois, contribui no desenvolvimento de competências relativas ao trabalho. Ao passo que não ajuda, pois, as atividades relativas à questão vocacional e profissional são superficiais ou raramente ocorrem. Nessa lógica, a Educação para a Carreira poderia contribuir, pois é uma modalidade de orientação de carreira, a ser desenvolvida de forma sistemática no contexto escolar e que pode auxiliar os estudantes na aquisição de competências-chave para o desenvolvimento da carreira 
e democratizando o acesso à OVP, atualmente restrita a poucos (MUNHOZ; MELO-SILVA, 2011).

A Educação para a Carreira surgiu para que a preparação acadêmica se equilibrasse com o desenvolvimento vocacional e profissional, harmonizando os currículos à essa demanda da sociedade (RODRÍGUEZ; CARMONA, 1995). Ela considera que os hábitos e atitudes relativos ao trabalho começam a desenvolver-se na infância, e os contextos familiar e escolar influenciam marcadamente sobre o desenvolvimento da carreira (MUNHOZ; MELO-SILVA, 2011) e que, portanto, a escola é trabalho (ou deveria sê-lo), a aula é um lugar de trabalho, o ensino e a aprendizagem são trabalhos, e os professores e alunos são trabalhadores (HOYT, 2005).

Outro achado significativo da pesquisa empírica refere-se à representação social sobre o processo de escolha de uma carreira ou profissão que é tido pelos estudantes como importante, difícil e estressante. A possibilidade de autorrealização através do trabalho é apontada pelos estudantes como o principal fator influenciador no momento da escolha. Nessa perspectiva, Hoyt (2005) ao defender a Educação para a Carreira afirma que preparar as pessoas para trabalhar deveria ser um objetivo básico do sistema educativo como um todo, haja vista que a necessidade humana de trabalhar existe em todas as pessoas. É a necessidade de fazer, de conseguir, de saber que é necessária para alguém mais e que o que a pessoa faz é importante. Carvalho (2014) também afirma que um dos problemas é que a visão educacional que se tem do trabalho é que ele está relacionado e submetido à lógica de mercado de trabalho e não como princípio educativo. Por isso, na Educação para a Carreira define-se amplamente a categoria trabalho como sendo o esforço consciente, distinto do aplicado em outras atividades não produtivas e descanso, dirigido a produzir benefícios socialmente aceitáveis para si mesmo e para outros (HOYT, 2005).

Por se tratar de uma dissertação de um Programa de Pós-Graduação na modalidade profissional, no próximo capítulo visando a melhoria educacional e com base nos dados construídos e analisados na pesquisa empírica, apresenta-se o produto técnico derivado também da revisão teórica e de situações identificadas ao longo do processo de pesquisa. 


\section{PRODUTO TÉCNICO}

O Mestrado Profissional tem como um de seus objetivos a transferência de conhecimento para a sociedade a fim de atender demandas sociais e econômicas, visando o desenvolvimento nacional, regional e local (BRASIL, 2019a). Nesse sentido, o produto técnico de um trabalho de conclusão de curso de um Mestrado Profissional é uma contribuição técnica ou proposta de intervenção em um determinado contexto que pode ter diferentes formatos. Dentre as possibilidades escolheu-se o Relatório Técnico Conclusivo, também chamado de Relatório Final ou Relatório Conclusivo, por acreditar que é a espécie que mais se adequa aos propósitos desta investigação.

O Relatório Técnico Conclusivo é um texto que contém informações sobre uma atividade realizada, desde seu planejamento até as conclusões. Indica em seu conteúdo a relevância dos resultados e conclusão em termos de impacto social e/ou econômico e a aplicação do conhecimento produzido (CAPES, 2018).

No caso específico deste trabalho, objetivou-se a produção de um relatório apresentando algumas características das iniciativas de trabalho com Projeto de Vida nas Secretarias Estaduais de Educação e das diretrizes e orientações pedagógicas elaboradas em âmbito Federal, e cotejá-las com uma análise crítica tendo como fundamento os pressupostos da Educação para a Carreira, abordagem de OVP defendida por este trabalho.

O interesse por investigar as propostas de Projeto de Vida surgiu da necessidade de constituir um referencial que seja útil precipuamente para a SEEDF, que não possui o serviço institucionalmente universalizado e que está em fase de elaboração das diretrizes pedagógicas para o desenvolvimento do Projeto de Vida. Mas, essa contribuição técnica também tem relevância e aplicabilidade mais ampla, podendo ser útil para qualquer Secretaria de Educação, entidade ou pessoa que se interesse em um relatório visando conhecer as outras iniciativas realizadas no país. Constitui-se, portanto, em um produto educacional para ser disseminado, analisado e utilizado para a reflexão, com vistas à inovação e ao atendimento das necessidades de OVP de estudantes.

A metodologia para a construção deste Relatório partiu da análise de conteúdo dos materiais pedagógicos e de documentos utilizados e/ou produzidos pelas Secretarias Estaduais de Educação e em âmbito federal, disponíveis em seus respectivos sites ou enviados via solicitação eletrônica realizada pelos Sistemas Eletrônicos do Serviço de Informações ao Cidadão (e-SIC) das Unidades Federativas. 
Foram analisadas as iniciativas e intenções dos 26 estados brasileiros e do Distrito Federal. Considerando a impossibilidade de explorar exaustivamente todas as informações e documentos obtidos, o que ultrapassaria os limites deste trabalho, analisou-se o material coletado por meio da análise categorial, que de acordo com Bardin (1977) é o desmembramento do texto em unidades ou categorias reagrupadas analogicamente.

As indagações que nortearam para a escolha das categorias de investigação frente às iniciativas de Projeto de Vida foram: quem elaborou a proposta? As atividades atendem a qual etapa da escolarização? Qual é o formato do trabalho? Quem o conduz? Houve uma formação específica para os condutores? Há pré-requisitos para essa atuação? Quais são os principais temas tratados? Em qual metodologia se baseiam?

Em 2016, o Conselho Nacional de Secretários de Educação (CONSED, 2016) apresentou algumas justificativas para as mudanças no ensino médio: a estagnação do IDEB do ensino médio desde 2011, o desempenho em Língua Portuguesa e Matemática sendo menor hoje do que em 1997, 1,7 milhão de jovens entre 15 e 17 anos fora de sala de aula, apenas 18\% dos jovens de 18 a 24 anos ingressa no ensino superior, apenas o Brasil tem um ensino médio padrão com 13 disciplinas.

Sob essas alegações, para iniciar o processo de reforma do modelo do ensino médio brasileiro, a Presidência da República instituiu a Medida Provisória ${ }^{\circ}$ 746, de 2016, convertida posteriormente na Lei Federal n ${ }^{\circ}$ 13.415, de 16 de fevereiro de 2017 que trouxe alterações para as diretrizes e bases da educação nacional. Dentre as alterações acrescidas, e a que se relaciona diretamente com o objeto de estudo desta investigação, encontra-se a seguinte prescrição "os currículos do ensino médio deverão considerar a formação integral do aluno, de maneira a adotar um trabalho voltado para a construção de seu projeto de vida e para sua formação nos aspectos físicos, cognitivos e socioemocionais" (BRASIL, 2017). Com a proposição da Medida Provisória e Lei Federal acima mencionadas muitos estados iniciaram um processo de reforma de suas matrizes curriculares tendo em vista a inclusão da temática Projeto de Vida nos processos formativos dos estudantes.

Este produto técnico está estruturado em 3 seções: na primeira apresenta-se algumas características das iniciativas de trabalho com Projeto de Vida nas Secretarias Estaduais de Educação. A segunda seção retrata as diretrizes e orientações pedagógicas elaboradas em âmbito Federal. Na terceira seção faz-se uma análise crítica geral dos documentos analisados cotejando-os com os fundamentos da Educação para a Carreira. 


\subsection{CARACTERÍSTICAS DAS INICIATIVAS DE PROJETO DE VIDA NAS SECRETARIAS DE ESTADO DE EDUCAÇÃO}

Apresenta-se abaixo as características das propostas de Projeto de Vida nas Secretarias de Estado de Educação nos 26 estados, em ordem alfabética, e por fim, no Distrito Federal. As categorias escolhidas para essa apresentação são: origem da proposta, etapa de ensino em que é desenvolvida, natureza da proposta, profissional responsável pelo desenvolvimento, prérequisitos e formação dos responsáveis pelo desenvolvimento, conteúdo e metodologia. Nem todas as informações obtidas em algumas Secretarias de Estado de Educação contemplam todas as categorias, mas apresenta-se um panorama geral dos achados.

\section{Acre (AC)}

No Acre o Projeto de Vida trata-se de uma disciplina da parte diversificada da matriz curricular do EMTI e do Novo Ensino Médio. Desde 2017 vem sendo ofertada apenas nas escolas de ensino médio que adotam a oferta em tempo integral, mas com as mudanças na LDB, no que diz respeito a reforma do Ensino Médio, a disciplina a partir desse ano (2019) constará na nova matriz curricular a ser executada em dez escolas piloto do Novo Ensino Médio e implantada gradativamente na rede.

O documento norteador utilizado na disciplina Projeto de Vida é originário do Instituto de Corresponsabilidade pela Educação (ICE), uma entidade sem fins econômicos, criada em 2003 por um grupo de empresários motivados a conceber um novo modelo de escola.

A disciplina Projeto de Vida utiliza o modelo da Escola da Escolha, uma metodologia pedagógica desenvolvida pelo ICE, que busca desenvolver habilidades cognitivas e nãocognitivas capazes de orientar o jovem no desenvolvimento de um projeto para si. Que ele possa se apropriar de valores e habilidades necessárias para o trânsito neste novo século e sonhar com a possibilidade de uma vida e um mundo diferentes.

Para trabalhar com a disciplina de Projeto de Vida, o professor precisa ter licenciatura plena para atuar no ensino médio e perfil para desenvolver a metodologia, e principalmente que acredite na superação das dificuldades dos alunos, como também fazer o curso de formação continuada ofertado pela SEE/AC.

As aulas são ministradas de acordo com a seguinte organização: no primeiro ano abordam-se os macrotemas identidade, valores, responsabilidade social e competências para o século XXI. Já no segundo ano explora-se: sonhar com o futuro, planejar o futuro, definir as ações e rever o projeto de vida. Os educadores recebem um material com os planos de aula, inclusive com a duração de cada atividade a ser desempenhada. 


\section{$\operatorname{Alagoas}(\mathbf{A L})$}

As primeiras reflexões sobre Projeto de Vida, no âmbito da Secretaria da Educação de Alagoas, iniciaram em 2015 com a instituição do Programa Alagoano de Ensino Integral cujas atividades curriculares estavam organizadas em macrocampos, dentre eles o "Juventude e Projeto de Vida" que incumbia as escolas de fomentarem o desenvolvimento do projeto de vida, destinando-se a desenvolver no estudante uma articulação do conhecimento escolar com os propósitos de vida (profissionais, socioemocionais, culturais) do indivíduo.

Os avanços em relação ao Projeto de Vida ficaram evidenciados com a criação do Projeto Orientador de Turma, que consiste em uma atividade complementar componente do currículo com duas horas por semana em todas as séries do ensino médio visando a construção do Projeto de Vida e a Formação Cidadã dos estudantes. Nesse Projeto realiza-se um acompanhamento sistematizado de orientação dos estudantes pautado na atenção individualizada e humanizadora do sujeito, bem como no desenvolvimento do processo de aprendizagem e do projeto de vida.

As unidades de ensino precisam dispor de um docente (monitor ou efetivo) por turma para mediar as relações e as aprendizagens, identificando e desenvolvendo as potencialidades e as experiências dos estudantes a fim de que se tornem protagonistas de suas próprias histórias. Para ser Docente Orientador de Turma o docente deve ter elevado nível de comprometimento com a educação pública, organizado, gentil, empático, capacidade para escuta ativa, olhar sensível para os fenômenos das juventudes, habilidades para mediar conflitos e intervir em determinadas situações; compreensivo diante das diversas realidades com as quais terá que lidar, agindo com firmeza, quando necessário; conhecedor das leis educacionais, e buscar constantemente compreender o contexto sociohistórico e económico em que os estudantes estão inseridos.

A compreensão de um projeto de vida para o estado de Alagoas é a busca pelo desenvolvimento de habilidades cognitivas e não cognitivas, visando uma ampla orientação para às juventudes do estado, incentivando os estudantes para a construção de seus sonhos. Diante dessa concepção, a SEE/AL construiu instrumentos para o trabalho pedagógico com o projeto de vida: roteiro inicial para as primeiras reflexões e cartilhas que visam situar o docente e o estudante. $\mathrm{Na} 1^{\mathrm{a}}$ série realizam-se atividades que proporcionam o autoconhecimento, a relação com o outro e o planejamento de vida. A $2^{\mathrm{a}}$ série retoma o planejamento reavaliando objetivos, metas e compromissos. E por fim, na $3^{\mathrm{a}}$ série desenvolvem-se reflexões que preparem para a vida e para experiências fora da escola. 
A SEE/AL desenvolve formação continuada com as unidades integrantes do programa visando instrumentalizar os docentes para o trabalho com foco nas competências socioemocionais para o desenvolvimento do Projeto de Vida.

\section{Amapá (AP)}

O trabalho com a questão do Projeto de Vida no estado do Amapá iniciou-se com a volta da discussão ampla da educação integral trazida pelo Plano Nacional de Educação em 2014, pelo Plano Estadual de Educação em 2015 e pelo lançamento da Medida Provisória 746/2016 que precedeu a Lei $n^{\circ}$ 13.415/2017. O Amapá fez adesão ao Programa de Fomento à Implantação das Escolas de EMTI junto ao Ministério da Educação (MEC) e buscou o apoio técnico perante o ICE. Diante dessa parceria público-privada foi implantado em algumas escolas o modelo da Escola da Escolha, uma metodologia pedagógica e de gestão escolar desenvolvida pelo instituto, sendo denominadas no estado de Escolas do Novo Saber.

O Projeto de Vida atende apenas o ensino médio e compõe a parte diversificada do seu currículo. A sua metodologia teve origem nos estudos do educador brasileiro Antônio Carlos Gomes da Costa, que criou o conceito de Educação Interdimensional e Pedagogia da Presença, os quais aparecem como pilares do modelo pedagógico proposto pelo ICE.

As aulas de Projeto de Vida são desenvolvidas por professores da equipe docente da escola, que seguem as orientações das apostilas e recebem formação e material para ser utilizado em sala de aula pelo ICE. As aulas são ministradas de acordo com a seguinte organização: no primeiro ano abordam-se os macrotemas identidade, valores, responsabilidade social e competências para o século XXI. Já no segundo ano explora-se: sonhar com o futuro, planejar o futuro, definir as ações e rever o projeto de vida. Os educadores recebem um material com os planos de aula, inclusive com a duração de cada atividade a ser desempenhada.

Atualmente, o trabalho vem ocorrendo em oito escolas da rede pública estadual de ensino e para a realização das aulas são resguardados dois módulos/aula semanais. Mas há a previsão de implantação desta proposta em mais quatro escolas.

\section{Amazonas (AM)}

No Amazonas, o Projeto de Vida é um componente curricular da parte diversificada do currículo desenvolvido nas escolas de EMTI que participam do programa de fomento do MEC e nas duas escolas bilíngues em tempo integral da rede pública do estado. As unidades escolares recebem material didático da componente curricular e os professores participam de formações continuadas. Essa componente desenvolve atividades como visitas técnicas, feiras de profissão, palestras, workshops, projetos de empreendedorismo, entre outras.

\section{Bahia (BA)}


Em 2017, a Secretaria de Educação do Estado da Bahia se aliou ao Instituto Aliança (IA), uma associação sem fins lucrativos qualificada como organização da sociedade civil de interesse público que desenvolve um trabalho voltado ao desenvolvimento e aperfeiçoamento de metodologias e produtos educacionais, para a realização de uma experiência piloto em dois Centros de Educação Profissional do Estado da Bahia, com implementação das disciplinas de Projeto de Vida e Mundo do Trabalho no currículo das Escolas Profissionais Integrais em Tempo Integral, com metodologia já desenvolvida pelo IA no estado do Ceará.

O intuito da inclusão destas disciplinas no currículo é promover em sala de aula a interdisciplinaridade e contextualização com a realidade histórico-cultural dos estudantes, e desenvolver competências para a inserção profissional, enquanto trabalhadores ou empreendedores e dotá-los de elementos para que realizem seu planejamento pessoal.

Os professores e técnicos da Educação Profissional Integrada ao EMTI, que foram contemplados com essa iniciativa, participaram de formações realizadas pela SEE/BA em parceria com o IA.

\section{Ceará (CE)}

O trabalho com o Projeto de Vida no âmbito do estado do Ceará ocorre nas Escolas Estaduais de Educação Profissional, iniciado pela SEDUC em 2008. O currículo integral nessas escolas conta com os conteúdos previstos para o ensino médio, relacionados aos cursos técnicos, além de uma parte diversificada, com temas voltados para o desenvolvimento pessoal e social e para o contexto das relações do trabalho, correspondendo às unidades curriculares Projeto de Vida (240h em 3 anos) e Mundo do Trabalho (100h em 2 anos).

Os materiais didáticos utilizados foram organizados pelo Instituto Aliança (IA), uma associação sem fins lucrativos qualificada como organização da sociedade civil de interesse público que desenvolve um trabalho voltado ao desenvolvimento e aperfeiçoamento de metodologias e produtos educacionais, por encomenda da SEDUC.

Os componentes curriculares Projeto de Vida e Mundo do Trabalho devem ser lotados, preferencialmente, por professores que participaram das formações oferecidas pela SEDUC em parceria com outras instituições. As capacitações são vivenciais e realizadas bimestralmente, tendo por base a metodologia proposta nos Planos de Aulas a serem desenvolvidos junto aos estudantes, seguida da discussão e apresentação dos referidos Planos.

A metodologia desenvolvida é baseada no conceito ampliado de saúde e de qualidade de vida, no desenvolvimento de competências e na participação e protagonismo juvenil. As diversas saúdes serão trabalhadas ao longo dos três anos de ensino médio, aliando atividades vivenciais, cognitivas, corporais e práticas. 
Os professores têm um papel fundamental na implementação dessa proposta pois são os facilitadores de todo o processo junto aos estudantes. Os cadernos do professor são estruturados com base na metodologia participativa do IA e indicam o passo a passo das unidades curriculares apresentando os planos de aulas de forma detalhada.

Na unidade curricular de Projeto de Vida o primeiro ano do ensino médio aborda-se a relação do estudante consigo mesmo, enfocando as saúdes emocional, física, a intelectual e a espiritual. No segundo ano reflete-se sobre a relação com o outro e com o ambiente através do trabalho com as saúdes familiar, relacional, comunitária e a ecológica. E no terceiro ano, o programa educacional é voltado para a saúde profissional.

\section{Espírito Santo (ES)}

A origem da proposta e participação no processo de construção do Projeto de Vida no estado do Espírito Santo, deu-se em 2015 nas escolas de tempo integral, através de uma parceria da Secretaria de Educação com o ICE na qual foi recebida via transferência de tecnologia educacional o modelo de educação em tempo integral que além das disciplinas da base nacional comum contempla a parte diversificada onde encontra-se a disciplina de Projeto de Vida.

Nas escolas de tempo parcial o componente integrador Projeto de Vida compreende a parte diversificada da organização curricular a partir de 2019 nas escolas-piloto do Novo Ensino Médio e será desenvolvido progressivamente em todas as escolas estaduais até o ano de 2022.

O Projeto de Vida faz parte do Programa Escola Viva é desenvolvido nas etapas de Ensino Fundamental II ( $6^{\circ}$ ao $9^{\circ}$ ano) e Ensino Médio. Esse componente curricular é cursado como disciplina com dois tempos semanais, nas escolas de tempo integral, e com um tempo nas escolas de tempo parcial, ambas com tempo de 50 minutos. Não possui atribuição de nota e é registrada como "cursado" ou "não cursado", mas com frequência registrada. No ensino médio as aulas de projeto de vida são assim estruturadas: no $1^{\circ}$ ano aborda-se "o autoconhecimento, eu no mundo", no $2^{\circ}$ ano trabalha-se "o futuro: os planos e as decisões" e no $3^{\circ}$ não há aulas estruturadas, mas faz-se o acompanhamento do Projeto de Vida de cada jovem.

As aulas de Projeto de Vida são desenvolvidas por professores de diferentes áreas de conhecimento que estejam lecionando na Unidade de Ensino e que tenham o perfil desejado para atender aos objetivos do componente como: possuir a capacidade de inspirar os estudantes; estar disposto a mergulhar num processo transformador; acolher os jovens que estão diante deles, repleto de sonhos, desejos, planos, de vida e de suas múltiplas juventudes; acreditar que o estudante é capaz de concretizar todas as etapas necessárias para realizar seu projeto de vida; ser parceiro de uma construção única. 
Todos os profissionais ingressantes nas unidades de tempo integral passam por Formação Inicial visando à introdução das bases teóricas e metodológicas, ao aprofundamento em Projeto de Vida (Escolas de Ano I e Ano II). Nas Escolas de tempo parcial, os professores de Projeto de Vida, bem como o diretor e o pedagogo da unidade escolar participam de Formação mensal realizada pelo Centro de Formação dos Profissionais da Educação do Espírito Santo (CEFOPE).

\section{Goiás (GO)}

No estado do Goiás, o componente curricular "Projeto de Vida" do Núcleo Diversificado da Matriz Curricular do Ensino Médio, desenvolvido nos Centros de Ensino em tempo Integral a partir de 2013 e em todas as unidades de Ensino Médio Parcial a partir de 2018 como proposta de implementação das práticas socioemocionais proposto pelo Novo Ensino Médio. É uma metodologia que visa trabalhar as habilidades socioemocionais a partir dos quatro pilares da educação (ser, fazer, conhecer e conviver) no sentido de auxiliar o estudante na construção da sua história de vida, e a traçar metas a curto, médio e longo prazo para a sua realização pessoal.

Para realizar esse trabalho as Escolas de Tempo Integral da Rede Estadual de Educação de Goiás contam com um material de apoio elaborado pelo ICE, constituído por dois cadernos. Um do professor que apresenta sugestões relacionadas à pratica docente, facultando aos docentes a possibilidade de incrementá-las com outros materiais. E outro destinado aos estudantes, contendo textos e sugestões de atividades.

O Projeto de vida é desenvolvido em todas as séries do ensino médio, inseminado na proposta como disciplina integrante da matriz curricular. No ensino integral, são destinadas duas aulas semanais na $1^{\mathrm{a}}$ e $2^{\mathrm{a}}$ séries e uma aula semanal na $3^{\mathrm{a}}$ série no qual é desenvolvido integrado à metodologia do pós-médio.

A Disciplina é ministrada por professores que compõem o quadro regular da escola, selecionados com base em um perfil que tem como premissas a comunicação, a sociabilidade e preferencialmente, formação nas áreas que envolvem psicopedagogia e conhecimento humano. Estes profissionais recebem formação inicial e continuada promovida pelo ICE e pela SEDUC/GO e são acompanhados por uma coordenação pedagógica específica nas unidades educacionais, a coordenação de núcleo diversificado.

Em ambas as modalidades de ensino, integral e parcial, a perspectiva é auxiliar os estudantes na descoberta do "seu eu", qual é "o seu sonho" e quais são "os seus talentos". Ter um projeto de vida implica em traçar um Plano de Ação para dar sentido e direção aos seus sonhos. É pensar no futuro em várias dimensões da sua vida. Diante desse trabalho, o estudante 
adquire condições de refletir e organizar-se no intuito de estabelecer o caminho para a construção do seu crescimento educacional, social e pessoal.

\section{Maranhão (MA)}

A origem da proposta de modelo pedagógico implantado nas escolas de Tempo Integral no Maranhão foi desenvolvida pelo ICE e implementada em parceria na rede estadual.

A etapa de ensino que o Projeto de vida é desenvolvido é no ensino médio. Trata-se de um componente curricular da Parte Diversificada do currículo do projeto escolar da Escola da Escolha desenvolvido nos Centros EducaMAIS da rede estadual. Ele é o seu eixo, sua centralidade e sua razão de existir. É fruto do foco e da conjugação de todos os esforços da equipe escolar. É nele que o currículo e a prática pedagógica realizam o seu sentido, no aspecto formativo e contributivo, na vida do jovem.

A proposta pedagógica do Projeto de Vida é desenvolvida por professores da rede estadual lotados nos Centros EducaMAIS. O pré-requisito para atuação é ser professor lotado na escola e selecionado pela equipe gestora para condução desse componente da Parte Diversificada.

A Secretaria de Educação possui uma Supervisão dos Centros de Educação em Tempo Integral e Profissional que é responsável pelo processo formativo dos professores de Projeto de Vida lotados na rede.

As aulas são ministradas de acordo com a seguinte organização: no primeiro ano abordam-se os macrotemas identidade, valores, responsabilidade social e competências para o século XXI. Já no segundo ano explora-se: sonhar com o futuro, planejar o futuro, definir as ações e rever o projeto de vida. Os educadores recebem um material com os planos de aula, inclusive com a duração de cada atividade a ser desempenhada.

\section{Mato Grosso (MT)}

Inspirado nas experiências de Projeto de Vida dos estados de São Paulo e Pernambuco, o estado do Mato Grosso, em parceria com o ICE, reorganizou a matriz curricular do EMTI acrescendo na parte flexível o Projeto de Vida. As escolas de EMTI são denominadas Escolas Plenas. Os professores dessa componente receberam formação na qual foram trabalhadas competências e habilidades socioemocionais.

\section{Mato Grosso do Sul (MS)}

No processo de implantação das escolas de EMTI, que vem acontecendo desde 2016, a Secretaria de Educação criou o Programa Escola da Autoria. Nesse contexto, o órgão firmou parceria com o ICE, que também atua em outros estados com assessoria pedagógica, com vistas à implementação do modelo pedagógico e de gestão denominado "Escola da Escolha". 
Uma das metodologias inseridas no contexto do modelo pedagógico, considerada como eixo central e que está presente como componente da matriz curricular do EMTI é o trabalho com Projeto de Vida que visa a formação de um jovem autônomo, solidário e competente. $\mathrm{O}$ ICE desenvolveu essa metodologia com base teórica no educador Antônio Carlos Gomes da Costa, autor das obras "Pedagogia da Presença", "Educação e Vida", "Protagonismo Juvenil" e "Aventura Pedagógica” que revelam o cerne da criação do Projeto de Vida.

O componente Projeto de Vida é desenvolvido nas turmas de $1^{\circ}$ e $2^{\circ}$ anos do ensino médio, com carga horária de 2 horas/aula semanais, com uso de material pedagógico estruturado, também fornecido pelo ICE. Essa componente é responsável pelo enriquecimento dos processos de aprendizagem, além do desenvolvimento de competências socioemocionais específicas, como autonomia, autoconfiança, respeito, iniciativa, resiliência, planejamento, capacidade de fazer escolhas, solidariedade, dentre outras, e é composta por grupos de aulas específicas, que tratam de temas que vão do autoconhecimento e reflexão do seu papel no mundo até planos para o futuro, escolhas e tomada de decisões, planejamento, metas e ações.

O Projeto de Vida é de responsabilidade de um professor qualificado que demonstra demostra maior aptidão à Pedagogia da Presença e maior afinidade com os estudantes. Esse profissional participa de formação continuada específica no primeiro ano de operacionalização da metodologia, seguida de uma formação de aprofundamento, no segundo ano, ambas oferecidas em conjunto pela Secretaria de Educação e pelo ICE.

\section{Minas Gerais (MG)}

Minas Gerais tem o Projeto de Vida inserido no Projeto Pedagógico das Escolas Estaduais que fazem parte do Programa de Fomento às Escolas de EMTI. O Projeto de Vida faz parte do campo de integração curricular que se configura em uma ação curricular ou em um conjunto de atividades pedagógicas e coletivas realizadas com grupos de estudantes em que se desenvolvem de forma integrada os conhecimentos e saberes.

A concepção do estado de Minas Gerais é que o Projeto de Vida é um plano traçado, um esquema vital que se encaixa na ordem das prioridades, valores e expectativas de uma pessoa que sonha com seu próprio destino e decide viver como quer. O projeto de vida, portanto, vincula-se de forma direta com a proposta de cada um em ser feliz e em buscar a felicidade. Por isso, ressalta-se a importância dos estudantes do ensino médio integral e integrado utilizarem o tempo na escola para pensarem o futuro.

Os responsáveis pelo desenvolvimento do trabalho com Projeto de Vida são professores que atuam na parte flexível do currículo, apresentam plano de trabalho e são selecionados por uma banca. A proposta de formação continuada específica encontra-se em construção. 


\section{Pará (PA)}

No estado do Pará o Projeto de Vida é desenvolvido no EMTI, juntamente com outras metodologias que buscam o protagonismo do estudante.

\section{Paraíba (PB)}

A proposta de trabalho com a temática de Projeto de Vida no estado da Paraíba iniciouse com uma parceria estabelecida entre a Secretaria de Educação e o ICE com a implantação do modelo pedagógico e de gestão "Escola da Escolha". São duas aulas semanais, que estão inseridas no currículo como disciplinas e são destinadas para os estudantes do ensino fundamental anos finais e para o ensino médio. Os estudantes do $9^{\circ}$ ano do ensino fundamental têm aulas de pré-médio e os do $3^{\circ}$ ano do ensino médio de pós-médio, visando prepara-los para os processos de transição.

Para a seleção do professor de Projeto de vida leva-se em consideração o perfil do profissional, este deve contemplar habilidades de escuta, flexibilidade, dinamismo, criatividade, ou seja, um perfil diferenciado. Os professores selecionados passam por duas formações específicas para atuarem com essa disciplina, uma no primeiro ano de aplicação e outra de aprofundamento no segundo ano.

Há também um material especifico que deve ser utilizado pelos professores durante as aulas e que foi elaborado pelo ICE. As aulas para o $1^{\circ}$ ano do ensino médio estão agrupadas de acordo com quatro grandes temáticas: identidade, valores, responsabilidade social e competências para o século XXI; e as aulas para o $2^{\circ}$ ano agrupam-se de acordo com as seguintes temáticas: sonhar com o futuro, planejar o futuro, definir as ações e rever o projeto de vida.

\section{Paraná (PR)}

No estado do Paraná, além de ser um tema transversal na Educação Básica, o Projeto de Vida é um componente na Matriz Curricular das escolas de EMTI. A origem da proposta para o componente se deu a partir do Programa de Fomento às Escolas de EMTI que buscava alinhar $\mathrm{o}$ currículo às exigências da Lei $\mathrm{n}^{\mathrm{o}}$ 13.415/2017. Em atendimento à essa determinação, o componente curricular já existente Mundo do Trabalho, passou a se chamar Projeto de Vida, e os professores que lecionavam naquele componente foram supriram este, por ser o mesmo perfil profissional.

O Projeto de Vida trata-se de um componente curricular da parte flexível do currículo, constituindo-se em 2 horas-aula semanais de frequência obrigatória para todos os alunos nas escolas de Ensino Médio de Tempo Integral. A proposta foi elaborada pela Coordenação da Célula do Ensino Integral, juntamente com a Coordenação de Currículo, Formação de 
Professores e Conteúdo Pedagógico. A fim de subsidiar as práticas pedagógicas dos professores a Secretaria de Educação realiza a disponibilização de materiais e a realização de formações específicas. Não há registro de notas, apenas o registro de frequência dos estudantes e o acompanhamento do percurso formativo dos estudantes pode se dar por meio de portfólio.

O objetivo central do componente curricular Projeto de Vida é ajudar o jovem a pensar e refletir sobre o que ele quer para o seu futuro e o que ele precisa fazer para atingir suas metas. Os temas trabalhados no $1^{\mathrm{o}}$ ano do ensino médio são: Identidade e diferença, valores, responsabilidade, ética e cidadania e competências socioemocionais. No $2^{\circ}$ ano trabalha-se a juventude, sonhos e planejamento, reflexões sobre a sociedade contemporânea e os componentes do projeto de vida. E por fim, no $3^{\circ}$ ano explora-se a qualificação e avaliação do projeto de vida.

A Secretaria de Educação do Paraná a fim de proporcionar uma formação mais dinâmica para os professores lançou o Programa Conexão Professor, que são palestras transmitidas online no canal da Secretaria de Educação no Youtube. Nesses vídeos, os especialistas em assuntos contribuem para o desenvolvimento das aulas dos professores além de apresentarem práticas de ensino das escolas paranaenses. Até o presente momento, já foram realizadas duas transmissões de vídeos relativas ao Projeto de Vida.

\section{Pernambuco (PE)}

A origem da proposta para trabalho com Projeto de Vida no estado de Pernambuco baseou-se no objetivo exposto na Lei de Diretrizes e Bases da Educação Nacional que estabelece que a educação objetiva preparar os jovens para o exercício da cidadania e qualificalo para o trabalho. Partindo dessa premissa, profissionais da área educacional desenvolveram o Projeto de Vida que é um laboratório de educação para a cidadania, para a participação democrática, para a ação social solidária, para escolhas voltadas para vida profissional e pessoal, interpessoal, social, ambiental e transcendental.

Em 2018, a Secretaria de Educação assinou um acordo coletivo internacional de educação e empregabilidade com a Aliança Novas Oportunidades de Emprego para Jovens (NEO) Brasil. O projeto já atua em alguns países da América Latina e Caribe. O Instituto Aliança (IA) é a agência executora do NEO Brasil no estado de Pernambuco, uma parceria entre a iniciativa privada, governo e sociedade civil que objetiva incrementar as oportunidades de trabalho para jovens mediante o fortalecimento e aperfeiçoamento dos serviços de formação, orientação vocacional e inserção laboral das escolas de educação profissional da Secretaria de Educação do Estado de Pernambuco. 
Diante do convênio firmado foi desenvolvido o Projeto de Capacitação de Educadores em "Projeto de Vida na Escola" com publicações de planos de aula que apoiam os educadores na formação dos estudantes. O material foi desenvolvido pela equipe da S\&OL - Siqueira \& Oliveira Consultoria e Assessoria em Psicologia LTDA, uma empresa de consultoria formada por profissionais que atuam no terceiro setor brasileiro estabelecendo parcerias com Organizações Sociais e Poder Público.

Os planos de aula dividem-se em quatro eixos estruturadores: identidade, autoeficácia, elaboração do Projeto de Vida e Projeto de Carreira. Cada eixo contempla um conjunto de 10 planos de aulas, que orientam os educadores na formação dos estudantes com duração de 2 horas semanais cada, totalizando, ao final, 80 horas de formação dos jovens.

O Projeto de Vida, como o nome sugere, é do que uma atividade extracurricular para os estudantes do ensino médio das escolas integrais e técnicas do estado de Pernambuco. Trata-se de um estímulo novo e de uma filosofia interdimensional a fim de que diminuísse os índices de evasão e auxiliassem os jovens a refletirem para um futuro em todas as esferas de sua vida.

Os professores da Rede Estadual de Educação atuantes nesse projeto não podem se contentar em serem conteudistas ou transmissores de conhecimentos, mas devem ser uma influência sobre os educandos e que esteja voltada para uma ação educativa permeada de significados. Ao se criar o Projeto de Vida, ocorreram formações na qual professores multiplicadores foram capacitados e encontram-se aptos para fazer parte do projeto.

\section{Piauí (PI)}

Anterior ao programa de fomento do MEC, a rede pública de ensino do estado do Piauí já contava com escolas de EMTI que desenvolviam iniciativas de protagonismo do juvenil materializadas pelo trabalho com Projeto de Vida. Esse trabalho viabiliza aos estudantes refletirem e construírem os caminhos a serem seguidos em suas trajetórias.

\section{Rio de Janeiro (RJ)}

No estado do Rio de Janeiro o Projeto de Vida constituiu-se em um dos componentes curriculares que compõem o Núcleo Articulador, parte integrante da matriz curricular das escolas que fazem parte do Programa de Educação Integral. A proposta pedagógica foi desenvolvida pela Secretaria de Educação em parceria com o Instituto Ayrton Senna (IAS), uma organização sem fins lucrativos que tem o objetivo de dar a crianças e jovens brasileiros oportunidades de desenvolver seus potenciais por meio da educação de qualidade. No modelo curricular em questão, a Base Nacional Comum é enriquecida por um Núcleo Articulador que tem alicerces nos princípios de educação integral para o século XXI e do protagonismo juvenil. 
A proposta iniciou-se em 2013 com uma escola piloto e atualmente está presente em mais de 165 escolas da rede estadual do Rio de Janeiro.

O componente curricular Projeto de Vida, tem por objetivo formar cidadãos capazes de intervir na realidade e modificá-la a partir de uma perspectiva global e democrática. Tem um importante papel no estímulo a descoberta das habilidades e competências cognitivas e socioemocionais de cada estudante. Visa construir no jovem uma rotina de reflexão sobre suas perspectivas e escolhas, bem como o hábito de criar conexões entre o seu cotidiano e o mundo. É um instrumento extremamente útil para tornar a prática educativa eficaz em dotar os alunos de estratégias e atitudes que lhes permitam enfrentar problemas e encontrar soluções.

O Projeto de Vida é desenvolvido na etapa final da educação básica, em turmas de ensino médio nas unidades escolares que ofertam a proposta. As aulas são ministradas por professores da rede estadual em efetiva regência nas escolas que ofertam educação integral. $\mathrm{O}$ pré-requisito é ser professor da rede estadual e ter qualquer licenciatura, uma vez que recebem formação específica para atuar neste componente.

As formações iniciais foram realizadas pela equipe de agentes técnicos e especialistas do IAS. O referido Instituto também formou uma equipe de docentes estaduais para atuar como formadores internos e replicar a proposta. Por isso, atualmente as formações referentes à este componente são planejadas, organizadas e ministradas pela Superintendência de Desenvolvimento de Pessoas. A Superintendência, em parceria com o IAS, também oferta regularmente cursos online para os professores que atuam na proposta.

\section{Rio Grande do Norte (RN)}

O Rio Grande do Norte aderiu ao Programa de Fomento à Implantação das Escolas de EMTI junto ao MEC e buscou o apoio técnico perante o ICE para a consolidação do ProMédio Integral. Diante desse convênio público-privado, desenvolve-se Projeto de Vida em 39 escolas de EMTI do sistema de ensino, com o objetivo de ampliar o tempo do jovem estudante na escola, inserindo-o num modelo pedagógico da Escola da Escolha, elaborado pelo ICE, que traz inovações em conteúdo da ação educativa, constituindo-se sobre 3 eixos fundamentais: formação acadêmica de excelência; formação para a vida; formação para o desenvolvimento das competências do século XXI. O modelo pedagógico tem como ideal formativo o jovem e seu projeto de vida, no qual ao final da Educação Básica o jovem tenha constituído uma forte base de conhecimentos e de valores; apresentando-se como parte da solução dos problemas reais, desenvolvendo competências que o permitam seguir nas várias dimensões da sua vida, executando o projeto construído e idealizado para o seu futuro ou o seu Projeto de Vida. 
O Projeto de Vida é uma metodologia de êxito (disciplina), da parte diversificada do currículo, que tem como objetivo estimular e despertar no estudante a necessidade de reconhecer, construir e incorporar valores que promovam atitudes de não indiferença em relação a si próprio, ao outro e ao seu entorno social; sistematizar o produto de suas reflexões e aprendizados que deverão subsidiar a elaboração do Projeto de Vida; motivando o estudante a elaborar seu Projeto de Vida. São ofertadas duas aulas de 50 minutos semanais de Projeto de Vida: $1^{\text {a }}$ série: Dedica-se ao eixo "O auto-conhecimento, eu no mundo", ao reconhecimento da importância dos valores, a existência de competências fundamentais que se relacionam e se integram, entre outros aspectos. $2^{\mathrm{a}}$ série: Dedica-se ao eixo "O Futuro: os planos e as decisões". Nessa etapa, os jovens documentam suas reflexões e tomadas de decisões no Guia Prático para a Elaboração do Projeto de Vida. $3^{\text {a }}$ série: dedica-se inteiramente à vida escolar e ao acompanhamento do seu Projeto de Vida, suas metas e objetivos estabelecidos no ano anterior.

Cada escola possui dois professores de Projeto de Vida, eles e o Coordenador Pedagógico são previamente capacitados. Os docentes de Projeto de Vida devem possuir a capacidade de inspirar o jovem, através da Pedagogia da Presença, sendo afirmativos em suas vidas. Também devem estar dispostos a mergulhar num processo transformador que envolverá muita subjetividade e objetividade, pois, ao mesmo tempo em que deverão provocar nos jovens o despertar sobre os seus sonhos, suas ambições, aquilo que desejam para as suas vidas, onde almejam chegar e que pessoas que pretendem ser, deverão levá-los a refletir sobre a ação, sobre as etapas que deverão atravessar e sobre os mecanismos necessários para chegar lá.

Todos os professores de Projeto de Vida passam por formação inicial, com o objetivo de apresentar as bases conceituais e metodológicas do modelo da Escola da Escolha, e formação de aprofundamento em Projeto de Vida. O objetivo é assegurar o pleno desenvolvimento da Metodologia de Êxito Projeto de Vida por meio da execução das aulas de acordo com as respectivas diretrizes e orientações, bem como os Princípios Educativos da Escola da Escolha, onde são disponibilizados os cadernos das aulas estruturadas de Projeto de Vida para os professores.

\section{Rio Grande do Sul (RS)}

O trabalho com Projeto de Vida no Rio Grande do Sul foi construído pelo Departamento Pedagógico da Secretaria de Educação, baseada na metodologia da Escola da Escolha, do ICE e é um componente curricular desenvolvido no ensino médio de tempo integral.

Para atuar no Projeto o pré-requisito é necessário ser professor, sendo desejável que tenha características relacionadas à proatividade e dinamismo, e é necessário participar de 
capacitação. Em 2018, oportunizou-se capacitação e formação aos professores ministrantes das 12 escolas envolvidas, em formato presencial e à distância.

\section{Rondônia (RO)}

A proposta de abordar o Projeto de Vida no estado de Rondônia faz parte da metodologia Escola da Escolha do ICE, parceiro do estado de Rondônia na implantação do Programa Escola do Novo Tempo.

O Projeto de Vida é um componente curricular da parte diversificada da matriz desenvolvida nas escolas de ensino médio de tempo integral pertencente ao Programa Escola do Novo Tempo. O Projeto de Vida para os $1^{\circ}$ e $2^{\circ}$ anos do ensino médio possuem 80 horas anuais para cada ano e para o $3^{\circ}$ ano o currículo tem sequência nas aulas de pós-médio com carga horária de 80 horas anuais. A metodologia empregada possui temas específicos e uma diretriz operacional.

O objetivo do projeto é que os estudantes ao final do Ensino Médio tenham construído seu Projeto de Vida, que não significa ajudá-los na definição de uma carreira profissional, mas antes, de definir quem eles querem ser; que pessoas querem ser; que valores querem construir e instituir em sua vida como fundamentais; que conhecimentos esperam ter constituído de maneira a ter ampliado e diversificado o repertório e que, no conjunto, o apoiarão na tomada de decisões sobre os diversos domínios de duas vidas, ou seja, a vida pessoal, social e produtiva.

Os responsáveis pelo desenvolvimento das atividades são professores selecionados das diversas disciplinas da Base Nacional Comum Curricular com dedicação integral de 40 horas semanais nas Escolas do Programa Novo Tempo. A definição do professor é de acordo com o perfil de desenvolvimento das aulas. São três professores por escola, sendo dois para Projeto de Vida e um para Pós-Médio, de modo que semanalmente estes realizem o alinhamento e planejamento em conjunto.

Os professores atuantes no componente curricular recebem formação de Projeto de Vida e Aprofundamento em Projeto de Vida. Essas formações visam ao esclarecimento dos pressupostos teóricos que sustentam essa prática, bem como do desenvolvimento da metodologia em sala de aula, com vistas a apoiar as entregas para os estudantes e para a escola como um todo.

\section{Roraima (RR)}

A partir de 2017, após o incentivo do Programa de Fomento do MEC, Roraima iniciou o processo de implementação do EMTI com as iniciativas de Projeto de Vida. O Projeto de Vida é o pilar da formação integral, trata-se de um componente curricular da parte diversificada da matriz e é considerado um momento importante da primeira série, pois subsidia os estudantes 
nas decisões que irão irá tomar sobre sua formação, sobretudo o itinerário que vai escolher seguir na segunda série.

\section{Santa Catarina (SC)}

O Projeto de vida é um dos componentes curriculares que fazem parte do macrocomponente Núcleo Articulador da matriz do Programa de EMTI. A proposta de Educação Integral no Ensino Médio do Estado de Santa Catarina se deu através de uma parceria da Secretaria de Educação com o Instituto Ayrton Senna (IAS), com apoio do Instituto Natura, da Capes, do Movimento Santa Catarina pela Educação, do BID e da FIESC. A proposta engloba o suporte à Secretaria para a elaboração de modelos de currículo, formação, acompanhamento e avaliação voltados para a promoção da educação integral.

No componente Projeto de Vida, os estudantes traçam estratégias para alcançar seu desenvolvimento presente e futuro, colaborativamente. Dessa forma, os jovens têm a oportunidade de pensar, planejar e começar a construir sua trajetória pessoal, com o apoio dos professores e da família. Busca-se conduzir os estudantes para o desenvolvimento de competências cognitivas e socioemocionais necessárias para viver no século XXI, realizar seus projetos de vida e construir um mundo melhor.

Nesse componente, ao trabalhar as três dimensões que o permeiam: identidade, projeção de futuro e mundo do trabalho, os jovens passam a fazer escolhas que dialogam com quem são e o que desejam para suas vidas. Tais escolhas têm implicações na vivência dos estudantes no próprio componente, em outros espaços curriculares da escola e para além do espaço escolar e está presente nos três anos de formação do Ensino Médio.

Os responsáveis por esse componente curricular são os professores. A cada semestre, as primeiras atividades do componente projeto de vida são dedicadas à composição dos times de orientação. Cada estudante é convidado a indicar três professores, em ordem de preferência, que gostaria que fossem seus orientadores. Essa indicação é feita considerando uma série de critérios, trabalhados durante as atividades, e uma lista de professores designados pela escola para orientarem os alunos daquela série do Ensino Médio. Os estudantes das diversas turmas podem indicar quaisquer professores dessa lista - o que, ao final, possibilita que os times de orientação sejam compostos por alunos de turmas diferentes.

Formações são realizadas ao longo do ano com equipes e especialistas do IAS. Nesses encontros são discutidas as metodologias de ensino e as mudanças curriculares necessárias para a formação integral. Além disso, as equipes recebem acompanhamento ao longo do ano. Os gestores e coordenadores participantes do programa fazem semestralmente formação continuada para avaliarem o funcionamento do programa em suas unidades escolares. No fim 
de cada ano, também é realizado um Seminário de Boas Práticas, onde as escolas apresentam seus trabalhos exitosos para outras escolas participantes do programa.

\section{São Paulo (SP)}

O trabalho com o Projeto de Vida no estado de São Paulo ocorre no âmbito do Programa Ensino Integral que fora implementado em 2012 como um modelo de escola que propicia aos estudantes além das aulas que constam no currículo escolar, oportunidades para aprender e desenvolver práticas que irão apoiá-los no planejamento e execução do seu Projeto de Vida. O Projeto de Vida é o foco para onde convergem todas as ações da escola.

Em 2014, foram estabelecidas diretrizes organizando o funcionamento das escolas estaduais do Programa Ensino Integral. Nela constam orientações acerca do Projeto de Vida desde os anos iniciais do ensino fundamental até o ensino médio.

Nos anos iniciais do ensino fundamental o Projeto de Vida é um eixo estrutural da gestão pedagógica consistindo em ações integrantes de um projeto de convivência que objetiva fornecer ao aluno condições de se aproximar do seu Projeto de Vida enfatizando-se o protagonismo infantil, a educação emocional e as diferentes linguagens.

Nos anos finais do ensino fundamental o "Projeto de Vida: Valores para a Vida Cidadã" e no ensino médio o "Projeto de Vida" é uma atividade complementar da parte diversificada do currículo que consiste na construção de um documento pelo aluno, em que ele expressará metas e definirá prazos, objetivando identificar e desenvolver suas aptidões, com responsabilidade individual, responsabilidade social e responsabilidade institucional, esta última em relação à sua escola. A avaliação desse componente curricular se dá mediante um parecer descritivo a ser elaborado ao final de cada semestre, pelo professor, versando sobre atitudes e ações do aluno que forem observadas, tendo como base a obtenção das competências relativas aos quatro pilares da educação.

Os professores para atuarem com Projeto de vida precisam de habilitação/qualificação de qualquer disciplina da Base Nacional Comum. Destaca-se que inclusive os Licenciados em Pedagogia são contemplados na atribuição dessas aulas. O professor de Projeto de Vida é o responsável pela disciplina e todos os educadores são corresponsáveis pelo desenvolvimento do Projeto de Vida dos alunos.

Recentemente, em maio de 2019, o Programa Inova Educação foi lançado e prevê que a partir de 2020 o Projeto de Vida seja um novo componente curricular para todas as escolas de anos finais do ensino fundamental e de ensino médio. A fim de que todos os docentes possam atuar a Escola de Formação e Aperfeiçoamento dos Profissionais da Educação do Estado de São Paulo ofertará formações específicas. 


\section{Sergipe (SE)}

O trabalho com Projeto de Vida realizado no estado de Sergipe é decorrente de uma parceria da Secretaria de Educação com o ICE. O Projeto de Vida é central no modelo pedagógico e administrativo proposto pelo ICE.

Em Sergipe, o Projeto de Vida é componente curricular disposto na organização curricular das escolas de tempo integral, aprovado pelo Conselho Estadual de Educação em 2017 e está destinado a estudantes do Ensino Médio.

Projeto de Vida é um componente curricular, com carga horária de 2 horas semanais e demanda formação de professores, porém, como também é trabalhado como centralidade do modelo, ele se reflete em todas as disciplinas, sejam elas da Base Nacional Comum Curricular ou da parte Flexível, na rotina de gestão e nas práticas pedagógicas.

Inexiste abordagem psicológica ou terapêutica na disciplina de Projeto de Vida. Ela é ofertada nas três séries do ensino médio, sendo que na primeira série a abordagem é sobre sonhos e expectativas de futuros, na segunda, sobre como construir um projeto ou um plano de ação, com metas e estratégias e nas aulas da terceira, os professores se revezam em uma agenda de aulas com foco no ENEM versus um conjunto de slides sobre um mundo de possibilidades para além da carreira acadêmica. Nas duas primeiras séries do Ensino Médio, os professores recebem um caderno orientador contendo 40 aulas estruturadas para a primeira série e 40 aulas para a segunda, já na terceira série as aulas estruturadas dão espaço a discussões sobre carreiras e a preparação para o ingresso na educação superior.

Os responsáveis pela disciplina são professores da rede que manifestam seu interesse junto a equipe gestora e possuem disponibilidade de carga horária. Os professores passam por uma formação inicial preparatória e duas de aprofundamento. As formações são ministradas pelas equipes do ICE e da Secretaria de Educação.

\section{Tocantins (TO)}

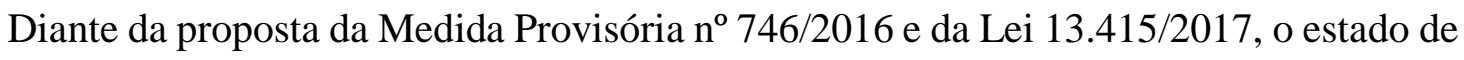
Tocantins aderiu à Política de Fomento à Implementação de Escolas de Ensino Médio Integral e, por meio da Secretaria de Educação, estabeleceu parcerias com o ICE, Instituto Qualidade no Ensino (IQE), Instituto Sonho Grande, Instituto Natura e Worldfund.

Nessa articulação, o ICE foi responsável por introduzir as bases teórico-metodológicas do Programa implantando as estruturas pedagógicas e de gestão na qual a centralidade encontrase no jovem e em seu Projeto de Vida. Assim, o Projeto de Vida integra a estrutura curricular das escolas de ensino integral participantes do Programa em Tocantins. A Secretaria de 
Educação tem a pretensão de estender a oferta desse componente para todas as escolas de ensino médio da rede estadual neste ano letivo de 2019.

Os princípios educativos do modelo pedagógico e o guia prático para a elaboração do Projeto de Vida no Ensino Médio são documentos produzidos e fornecidos pelo ICE e que norteiam a atividade pedagógica desenvolvida no componente curricular.

\section{Distrito Federal (DF)}

Desde 2015, a SEEDF iniciou uma discussão sobre uma nova arquitetura para o ensino médio da rede pública de ensino. Entre os anos 2017 e 2018, a equipe pedagógica do programa EMTI teve contato com os pressupostos e com materiais pedagógicos produzidos relativos ao Projeto de Vida nos encontros do Conselho Nacional de Secretários de Educação (CONSED). Também foi realizado pela equipe um estudo sobre as Competências do século XXI, Psicologia Comportamental Positiva, PNL e Coach. A partir desses estudos a equipe pedagógica preparou um workshop e uma palestra que ocorreram no segundo semestre de 2018, nos grupos das formações e em duas escolas. Outra ação desenvolvida foi a ministração de uma palestra sobre habilidades socioemocionais.

Em 2018, visando a participação ampla e democrática de todos os setores envolvidos na formulação de uma nova proposta de ensino médio, foram realizados Fóruns Regionais com a comunidade escolar a fim apresentar uma sugestão de proposta pedagógico-administrativa para o ensino médio para ser implantada a partir de 2020. Para suscitar o debate a Subsecretaria de Educação Básica elaborou uma coleção de textos para a discussão e contribuições, na qual constava um fascículo intitulado "Projeto de Vida: um olhar para o estudante" (DISTRITO FEDERAL, 2018).

O Projeto de Vida está inserido como uma das possibilidades de oferta de área temática ou oficina na parte flexível da matriz curricular das unidades escolares participantes do Programa de Fomento às Escolas de EMTI. Havendo um indicativo de expansão para a parte flexível do Novo Ensino Médio.

Os profissionais que podem atuar ministrando o Projeto de Vida são professores da SEEDF que participem do processo seletivo de aquisição de aptidão. Conforme a Portaria $\mathrm{n}^{\circ}$ 173, de 20 de junho de 2018, os pré-requisitos para atuação em Projeto de Vida era que o professor tivesse "habilidade para trabalhar com pedagogia de projetos e metodologias inovadoras e possuir capacidade de proposição e articulação da temática escolhida com enfoque no protagonismo e na autonomia juvenil”, além de uma entrevista e apresentação oral de um plano de trabalho e de uma análise curricular que pontua as formações em doutorado, mestrado, especialização ou cursos de aperfeiçoamento na área. 
Cabe ressaltar que o Centro de Aperfeiçoamento dos Profissionais de Educação (EAPE) oferta desde o segundo semestre de 2018 o curso "Construindo Novos Caminhos - a importância de se trabalhar projetos de vida na escola" para qualquer professor que se interesse em uma formação que aponte possibilidades de ressignificação do trabalho pedagógico, por meio da construção de projeto de vida na escola, utilizando recursos e ferramentas voltadas para o desenvolvimento humano.

Atentando-se ao movimento histórico em torno do objeto investigado, identificou-se que a SEEDF, por meio da Portaria $\mathrm{n}^{\circ}$ 171, de 21 de maio de 2019, instituiu um grupo de trabalho objetivando a elaboração de diretrizes pedagógicas para o desenvolvimento do componente curricular Projeto de Vida, a definição de conteúdos relativos à formação continuada envolvendo Projeto de Vida e a indicação de material didático que possa subsidiar o trabalho docente.

Realizado o mapeamento das iniciativas de Projeto de Vida nas Secretarias Estaduais de Educação, para se entender o que está posto hoje faz-se necessária também a apresentação das diretrizes pedagógicas para o trabalho com o Projeto de Vida em âmbito federal, haja vista que algumas dessas orientações foram lançadas após as Unidades Federativas já terem dado início aos seus modelos de trabalho.

\subsection{DIRETRIZES E ORIENTAÇÕES PEDAGÓGICAS PARA O TRABALHO COM PROJETO DE VIDA EM ÂMBITO FEDERAL}

Considerando as alterações ocorridas na Lei de Diretrizes e Bases da Educação Nacional pela Lei n n $^{\text {13.415/2017, a Resolução n }}$ 3, de 21 de novembro de 2018, atualizou as Diretrizes Curriculares Nacionais para o Ensino Médio contendo princípios e fundamentos para a orientação das políticas públicas educacionais. Um dos princípios apontados, e que dialoga diretamente com este trabalho, é o Projeto de Vida, considerado como uma estratégia de reflexão sobre a trajetória escolar na construção das dimensões pessoal, cidadã e profissional do estudante.

Ainda de acordo com a referida Resolução, tanto as propostas curriculares dos sistemas de ensino quanto as propostas pedagógicas das unidades escolares ofertantes de ensino médio devem considerar e contemplar o Projeto de Vida e Carreira dos estudantes e a sua formação integral, expressa por valores, e pelo desenvolvimento intencional dos aspectos físicos, cognitivos e socioemocionais, através de processos educativos significativos que promovam a autonomia, o comportamento cidadão e o protagonismo na construção de seu projeto de vida. 
Na atualização das Diretrizes Curriculares Nacionais, o Projeto de Vida e Carreira do estudante é visto como uma estratégia pedagógica cujo objetivo é promover o autoconhecimento do estudante e sua dimensão cidadã, de modo a orientar o planejamento da carreira profissional almejada, a partir de seus interesses, talentos, desejos e potencialidades.

Além da prescrição de inclusão de um trabalho voltado para a construção de Projeto de Vida nos currículos de ensino médio, presente na alteração da Lei de diretrizes e bases da educação nacional, no ano de 2017 foi instituída a Base Nacional Comum Curricular (BNCC) da Educação Infantil e Ensino Fundamental e em 2018 a BNCC do Ensino Médio. Ambos documentos que norteiam a educação básica brasileira expressam que uma das competências gerais a serem desenvolvidas pelos estudantes relaciona-se diretamente com Trabalho e Projeto de Vida:

Valorizar a diversidade de saberes e vivências culturais e apropriar-se de
conhecimentos e experiências que lhe possibilitem entender as relações próprias do
mundo do trabalho e fazer escolhas alinhadas ao exercício da cidadania e ao seu
projeto de vida, com liberdade, autonomia, consciência crítica e responsabilidade
(BRASIL, 2017b; 2018b).

A BNCC, como documento fundamental para nortear os novos modelos curriculares, reitera o foco no estudante, no seu protagonismo e no seu projeto de vida em todas as etapas da Educação Básica.

Em janeiro de 2019, a Coordenação-Geral de Ensino Médio do MEC encaminhou um ofício-circular para as Secretarias Estaduais de Educação documentos referentes ao Novo Ensino Médio objetivando ampliar os subsídios para a elaboração de Propostas de Flexibilização Curricular. Destacam-se dois documentos, que enfatizam a questão do Projeto de Vida: as orientações para a Construção das Propostas de Flexibilização Curricular e a Orientação pedagógica para trabalho com Projeto de Vida enquanto componente curricular.

As orientações para a Construção das Propostas de Flexibilização Curricular (BRASIL, 2019b) afirmam que em 2019 as escolas devem iniciar o desenvolvimento de atividades curriculares que apoiem o desenvolvimento do Projeto de Vida dos estudantes. Nessas ações, deve-se "ampliar o universo dos estudantes e o olhar destes sobre a vida, abordando sobre as diversas possibilidades de escolha presentes em seu percurso formativo e nas diversas dimensões da vida" (p. 5). O documento também ressalta o papel da escola de orientadora do processo que viabiliza ao estudante a construção do seu projeto de vida.

A Orientação Pedagógica para trabalho com Projeto de Vida enquanto componente curricular (BRASIL, 2019c) é um documento pedagógico norteador para o trabalho com Projeto de Vida. Destaca-se os principais aspectos: 
- O Projeto de Vida é conceituado como uma metodologia interdimensional que visa desenvolver habilidades cognitivas e não-cognitivas capazes de orientar o estudante no desenvolvimento de um projeto para si;

- O Projeto de Vida não é apenas escolha profissional, tampouco está dissociada do mundo produtivo, pois contribui para o autoconhecimento, para a capacidade de situar-se no mundo e reconhecer as possibilidades e para o desenvolvimento de valores e habilidades que contribuam para que o estudante faça boas escolhas ao longo da sua trajetória.

- O trabalho em torno do Projeto de Vida tem a capacidade de motivar e despertar o interesse dos estudantes a fim de direcioná-los para a construção do que esperam para si no futuro.

- O Projeto de Vida traz significado e preenche com valores a formação acadêmica dos componentes curriculares tradicionais.

- É necessário investimento na formação e aperfeiçoamento dos profissionais condutores dessas aulas. Recomenda-se que nas aulas use-se dinâmicas, recursos tecnológicos, os diversos espaços da escola e incentive-se o protagonismo e a autoria estudantil.

- Elenca-se quatro macrotemas ou eixos para a organização do componente curricular de Projeto de Vida: Autoconhecimento; Eu x Outro; Planejamento e; Preparação para o mundo fora da escola.

As orientações federais auxiliam a compreender a tônica que os trabalhos relativos à questão do Projeto de Vida nos diversos estados devem se materializar. Na próxima seção realiza-se uma análise crítica geral dos documentos analisados defrontando-se com os fundamentos da Educação para a Carreira.

\subsection{ANÁLISE CRÍTICA}

Após realizar a apresentação dos materiais pedagógicos e de documentos utilizados e/ou produzidos pelas Secretarias Estaduais de Educação e em âmbito federal foi possível chegar à algumas conclusões em relação ao trabalho com Projeto de Vida:

- Embora a ação de orientar e preparar para a vida em todas as suas dimensões seja uma representação social da função da escola, a realização deste serviço de forma institucionalizada e sistemática no ensino público brasileiro tem ganhado discussão e foco apenas nos últimos anos e, sobretudo, por força uma imposição legal. 
Percebe-se isso, pois a maioria dos estados se mobilizaram apenas após a promulgação da Medida Provisória 746/2016 e posterior Lei Federal 13.415/17.

- Outro aspecto que evidencia a inclusão deste tipo de trabalho no currículo apenas por imposição legal, por parte dos estados, é que preponderantemente estes circunscreveram as atividades de Projeto de Vida apenas na etapa do ensino médio, conforme previam os dispositivos legais supramencionados. Por outro lado, poucas são as unidades federativas que percebem a importância de que este trabalho seja realizado também em outras etapas da educação básica.

- Embora na prescrição trazida pela Lei $13.415 / 17$ não traga a obrigatoriedade de um formato específico para o trabalho com Projeto de Vida, observa-se que, predominantemente, os sistemas de ensino mantêm uma concepção curricular mais comum, estruturando o Projeto de Vida como uma disciplina segmentada. Poucos sistemas de ensino exploram e adotam concepções mais flexíveis e inovadoras, como núcleos articuladores, módulos, atividades, práticas e projetos contextualizados e articuladores de saberes, oficinas, laboratórios, desenvolvimento transversal de temas ou outras formas de organização que rompam com o trabalho fragmentado.

- Quase a totalidade dos estados se valeram de Parcerias Público-Privadas a fim de que as instituições privadas concebam a forma de trabalhar com essa temática, optando por uma determinada metodologia, realizando a formação continuada dos atuantes, e inclusive, em alguns casos, oferecendo-se planos de aulas minuciosamente detalhados para mera execução.

- Alguns estados parecem não ter uma concepção teórico-metodológica de trabalho com o "Projeto de Vida" solidamente fundamentada, apenas elencando-se temas a serem trabalhados e discutidos sem um embasamento procedimental mais concreto.

Contrapondo-se aos pontos elencados dos modelos já existentes e na tentativa de respondê-los adequadamente, defende-se que a Educação para a Carreira, é uma abordagem de OVP pertinente aos propósitos de trabalho com Projeto de Vida diante das determinações legais e das orientações pedagógicas instituídas e, também, para além delas.

O primeiro aspecto a se destacar é que essa abordagem tem no seu cerne o esforço da educação pública para cumprir com os seus propósitos. Trata-se do setor público, pensando e executando uma política de OVP para o público. Em contraposição ao estabelecimento de parcerias público-privadas, no que tange a gestão e idealização dos processos educacionais relativos ao trabalho com Projeto de Vida, defende-se a educação pública e democrática. Como 
Peroni (2012), acredita-se que as cooperações técnicas entre o público e o privado precisam ser vistas com muita cautela, pois redefine-se a função do Estado e das políticas sociais no que tange a quem deve construí-las e também na forma como a educação é reorganizada na lógica do mercado.

\footnotetext{
Quando abrimos mão da gestão democrática pela lógica gerencial, que quer um produto rápido e adequado às exigências do mercado no período atual, estamos pactuando com outra proposta de educação e sociedade e desistindo ou minimizando a importância da construção da democracia que historicamente não tivemos (PERONI, 2012, p. 29).
}

Outro elemento a se destacar é que a Educação para a Carreira aglutina elementos da OVP, pois não deve ser confundida como uma mera preparação para a escolha profissional, mas como um itinerário no qual os indivíduos realizam atividades de autoconhecimento, de conhecimento da sua realidade e oportunidades, de informação e orientação acerca do mundo do trabalho e de preparação para a tomada de decisões e para as transições. Nesse sentido, é uma formação longitudinal e que não estaria necessariamente restrita à etapa final da educação básica.

É contraditório afirmar que o Projeto de Vida não se resume a uma escolha profissional, mas circunscrevê-lo na etapa final da Educação Básica. Defende-se, portanto, o Projeto de Vida, na perspectiva da Educação para a Carreira, executado em todas as etapas e modalidades de ensino, a fim de que os processos de ensino-aprendizagem possam ser enriquecidos com o processo de desenvolvimento vocacional e profissional, possibilitando que os estudantes reflitam e se direcionem para a construção do que almejam para si e para o seu futuro em todas as dimensões da sua vida.

A proposta da Educação para a Carreira atende, entre outras, o desenvolvimento da competência "Trabalho e Projeto de Vida" proposta pela BNCC para toda a Educação Básica. Para facilitar a inserção das competências nos currículos, o Grupo de Desenvolvimento Integral do Movimento pela Base e o Center for Curriculum Redesign (2018) desenvolveram uma publicação com o objetivo de apoiar os sistemas, as unidades escolares e os docentes a compreenderem as competências gerais da BNCC e como elas progridem ao longo da Educação Básica.

No documento supramencionado a competência geral "Trabalho e Projeto de Vida" é dividida em duas dimensões, Projeto de Vida e Trabalho, que se subdividem ao todo em 7 subdimensões: Determinação, Esforço, Autoeficácia, Perseverança, Autoavaliação, Compreensão sobre o mundo do trabalho e Preparação para o trabalho. Além da subdivisão apresentada, subdimensões das competências são conceituadas e sugere-se uma progressão 
curricular ao longo da Educação Básica, conforme ilustra o quadro 6 no que tange a subdimensão da "autoeficácia".

Quadro 7 - Progressão curricular da subdimensão "Autoeficácia” da competência "Trabalho e Projeto de

\begin{tabular}{|c|c|c|c|c|}
\hline \\
\hline Autoeficácia & $\begin{array}{l}\text { Até o } 3^{\circ} \text { ano do } \\
\text { ens. fundamental }\end{array}$ & $\begin{array}{l}\text { Até o } 6^{\circ} \text { ano do } \\
\text { ens. fundamental }\end{array}$ & $\begin{array}{c}\text { Até o } 9^{\circ} \text { ano do ens. } \\
\text { fundamental }\end{array}$ & $\begin{array}{l}\text { Até o } 3^{\circ} \text { ano do ens. } \\
\text { médio }\end{array}$ \\
\hline $\begin{array}{l}\text { Confiança na } \\
\text { capacidade } \\
\text { de utilizar } \\
\text { fortalezas e } \\
\text { fragilidades } \\
\text { pessoais para } \\
\text { superar } \\
\text { desafios e } \\
\text { alcançar } \\
\text { objetivos. }\end{array}$ & $\begin{array}{c}\text { Reconhece que } \\
\text { suas ações e } \\
\text { capacidades } \\
\text { podem influenciar } \\
\text { os resultados que } \\
\text { deseja. }\end{array}$ & $\begin{array}{l}\text { Utiliza suas } \\
\text { experiências e a } \\
\text { de outros para } \\
\text { fortalecer a sua } \\
\text { capacidade de } \\
\text { agir em favor dos } \\
\text { resultados que } \\
\text { deseja. }\end{array}$ & $\begin{array}{l}\text { Conhece e acredita em } \\
\text { suas fortalezas e } \\
\text { capacidade de } \\
\text { influenciar resultados e } \\
\text { utiliza diferentes } \\
\text { formas de agir e pensar } \\
\text { para enfrentar desafios, } \\
\text { obstáculos e realizar } \\
\text { projetos presentes e } \\
\text { futuros com confiança. }\end{array}$ & $\begin{array}{l}\text { Percebe suas fortalezas e } \\
\text { fragilidades como } \\
\text { valores para influenciar } \\
\text { resultados, mobilizando } \\
\text { estratégias de } \\
\text { interdependência para } \\
\text { enfrentar desafios, } \\
\text { obstáculos e realizar } \\
\text { projetos presentes e } \\
\text { futuros com confiança. }\end{array}$ \\
\hline
\end{tabular}

Fonte: Grupo de Desenvolvimento Integral do Movimento pela Base e Center for Curriculum Redesign (2018)

Aplicando-se a Educação para a Carreira, longitudinalmente, o desenvolvimento das competências e valores pode se dar de forma progressiva e bem consolidada.

A Educação para a Carreira é uma modalidade de OVP voltada para o contexto educacional e que dialoga harmonicamente com as orientações pedagógicas para o trabalho com Projeto de Vida. Ela é uma abordagem pedagógica, que tem como pressuposto a atuação de professores que realizando técnicas de ensino-aprendizagem propiciam o desenvolvimento vocacional e profissional.

Haja vista que os sistemas de ensino possuem autonomia em relação à concepção pedagógica e à proposta curricular é possível que o trabalho com Projeto de Vida adquira o formato que seja compatível com a proposta de trabalho do sistema de ensino. Qualquer que seja a base da organização curricular, a Educação para a Carreira possui diversos modelos: o extracurricular (como um elemento adicional), o de disciplina própria (como assunto ou módulo específico dentro do currículo), o integrado a uma disciplina geral (como parte de um assunto ou módulo mais amplo dentro do currículo) e o integrado ao currículo (como eixo transversal nos diversos componentes curriculares). A aplicação destes modelos limita-se às possibilidades do contexto educacional e do nível de ensino que será desenvolvida.

Nas escolas cuja arquitetura curricular seja baseada em disciplinas, e não se opte pela criação de uma disciplina própria de Projeto de Vida, é duvidosa a capacidade de efetivação do prescrito pela legislação, porque, se os professores estão comprometidos com o programa de suas disciplinas, dificilmente terão condições de oferecer tratamento interdisciplinar e contextualizado ao necessário trabalho com Projeto de Vida. Nesse sentido, é necessário que os sistemas de ensino garantam a integralidade e a coerência das suas propostas curriculares, 
oferecendo ao trabalho com Projeto de Vida o mesmo valor e tratamento que são dedicados aos outros componentes curriculares, qualquer que seja a sua organização e formato curricular.

Os sistemas de ensino com arquitetura curricular flexível podem buscar assegurar tratamento interdisciplinar e contextualizado, visando a reflexão e construção do Projeto de Vida dos estudantes. Outra possibilidade é que o trabalho com Projeto de Vida seja tratado de forma transversal, permeando, pertinentemente, os demais componentes curriculares. É conveniente destacar que, as propostas curriculares devem assegurar, efetivamente, que, os estudantes reflitam sobre os seus projetos de vida nas diversas dimensões.

A possibilidade de atuação do Pedagogo, enquanto profissional da educação, que engloba ações docentes em qualquer programa ou projeto educacional, é uma característica da legislação brasileira que possibilita que se supere uma das principais barreiras ocorridas internacionalmente para a implantação dos programas de Educação para a Carreira: a recusa dos professores de absorverem mais uma atribuição por não se sentirem preparados ou por sentirem-se sobrecarregados. Entretanto, pressupõe-se a necessidade de uma capacitação específica para se trabalhar com a Educação para a Carreira, afim de que os professores que venham a desenvolver este trabalho entendam seus pressupostos e estejam habilitados e aptos a fazê-lo.

Considera-se que a Educação para a Carreira é pertinente para a colaboração da construção dos projetos de vida dos estudantes, oferecendo-lhes o suporte necessário para realizar escolhas mais conscientes e que levem em considerem a sua história de vida e a conjuntura em que estão inseridos. Consiste, dessa forma, em uma atividade que contribui para que o jovem atribua sentidos aos estudos e ao trabalho.

O escopo de ações pode ser diverso: avaliar os interesses, as habilidades e as capacidades através de dinâmicas, tratar a questão das escolhas e decisões e as suas implicações, apontar diferentes itinerários que um sujeito pode seguir, informar cursos técnicos e superiores, e sobre a construção de carreira.

O desenvolvimento da Educação para a Carreira pode auxiliar o estudante a se preparar para as transições e as escolhas atreladas a elas: dos anos iniciais para os anos finais do ensino fundamental, do ensino fundamental para o ensino médio regular ou técnico integrado, do ensino médio para o ensino superior, da transição escola para o trabalho e de possíveis retornos para as instituições de ensino diante da necessidade de educação e aprendizagem ao longo da vida.

Para além do autoconhecimento, do conhecimento acerca das profissões e do mercado de trabalho, é importante o desenvolvimento de valores relativos ao trabalho e de competências- 
chave que serão utilizadas, no futuro, para o planejamento, o desenvolvimento e a progressão na carreira, sujeita a tantas transições no mundo contemporâneo. Entre essas habilidades está a de "aprender a fazer escolhas", que será extremamente necessária no contexto do Novo Ensino Médio, que exige a opção por um itinerário formativo, ocasião na qual deverão escolher disciplinas de seu interesse para aprofundamento, com consequências para a futura carreira.

Faz-se necessário destacar que a Educação para a Carreira não se restringe ao auxílio para a escolha de um curso superior e pode colaborar também no planejamento para inserção no mercado de trabalho, pois a grande parte dos estudantes brasileiros ainda não chega à universidade, mas poderia dispor de auxílio especializado para refletir e planejar sua trajetória de trabalho, independentemente do nível de escolaridade alcançado. É por esta razão que se defende que o serviço de OVP seja ofertado desde o início da escolarização, pois tais competências exigem longo tempo para seu desenvolvimento, e favorecem a relação educaçãotrabalho.

Acredita-se que caso essas transições sejam mediadas processualmente por meio de reflexões e contextos de ensino-aprendizagem é possível construir e reconstruir sentidos aos estudos e ao trabalho, podendo-se impactar na redução dos índices de evasão da educação básica e no ensino superior. 


\section{CONSIDERAÇÕES FINAIS}

O desejo de testemunhar a pertinência e a relevância do serviço de OVP no contexto educacional permeia a vida do pesquisador e o mobilizou para a realização desta investigação. É preciso retomar as problematizações propostas para conduzir os trabalhos investigativos deste estudo. Propôs-se realizar a análise do papel da Educação para a Carreira na ampliação das representações sociais dos estudantes e na preparação para a realização de escolhas e tomada de decisões em seu Projeto de Vida. Para tanto, traçaram-se alguns objetivos específicos que conduzissem o processo investigativo.

Em relação ao objetivo de identificar o conteúdo e a estrutura das representações sociais dos estudantes sobre a escola, a sua função, a sua relação com a OVP e a escolha de uma carreira ou profissão, utilizou-se como aporte teórico-metodológico o modelo desenvolvido por Domingos Sobrinho e que articula a TRS e a Praxiologia de Bourdieu. Iniciou-se um esforço para explorar novas possibilidades explicativas relacionadas a área de OVP, ampliando a compreensão do diálogo proposto em torno das Representações Sociais e da Praxiologia Social por meio da aplicação vinculada à Educação para a Carreira. Esse modelo teórico vinculado à uma abordagem crítico-dialética viabilizou a leitura dos aspectos macro e microssociais.

As representações sociais, analisadas nesta pesquisa, são significados ou sentidos elaborados e partilhados coletivamente pelo grupo de estudantes concluintes da educação básica a respeito de temas vocacionais e que servem de guia para a ação deste determinado grupo de sujeitos. Em complementariedade à análise dessas representações, buscou-se apreender também os elementos da Praxiologia de Bourdieu, sobretudo o habitus, que se referem às condições materiais e simbólicas que estão na base da produção das representações sociais.

No decurso da investigação, teve-se a oportunidade de se aproximar do ser estudante, dar-lhes voz, entender suas justificativas, anseios e angústias, que foram sendo consolidadas ao longo da sua trajetória, por uma conjuntura social que regulam suas práticas, seu estilo de vida e que lhes confere uma identidade. Os sujeitos investigados, por serem estudantes da $3^{\mathrm{a}}$ série do ensino médio, puderam testemunhar as suas percepções diante de toda a sua trajetória escolar.

Por meio da aplicação de um questionário socioeconômico e cultural apreenderam-se os referentes empíricos do habitus estudantil, no qual destacam-se os costumes, experiências, percepção de influência, motivações, aspirações e outras regularidades do ser estudante deste campo social. 
As principais regularidades deste habitus que conseguiu-se desvelar foi que a maioria cursou a educação básica toda em escola pública; a profisssão/ocupação dos pais e das mães podem ser classificadas como predominantemente manuais, de baixa qualificação e remuneração; em relação à frequência, a conversa com familiares e a pesquisa ou leitura individual são as principais fontes de informação profissional dos estudantes, seguida pela conversa com colegas e, por último, a escola; quanto à ordem de importância da influência na OVP deles aponta-se, respectivamente, os familiares, a pesquisa ou leitura individual, a mídia, a escola e, por fim, os colegas; nunca frequentaram curso ou formação para alguma atividade ocupacional ou profissional; nunca exerceram trabalho remunerado; quanto à primeira aspiração para concluírem a educação básica apontam, na devida ordem, fazer um curso superior, estudar e buscar aprovação em um concurso público, inserir-se no mercado de trabalho, fazer curso técnico e ter o seu próprio negócio.

Identificou-se, também, que são estudantes que vivenciaram poucas ou nenhuma atividade na escola que os preparassem para o processo de escolha da carreira ou profissão. Encontrou-se no corpo discente predominante, cujas respostas confirmavam, a existência de um habitus construído, tal qual se faz presente e articula-se com a realidade social da região administrativa de Taguatinga, local em que se situa a unidade escolar dos sujeitos investigados.

Por meio da pesquisa empírica foi possível notar que o habitus estudantil conflui e dialoga com as representações sociais dos estudantes, haja vista que por meio das representações é possível aproximar-se do habitus e vice-versa.

Através da aplicação do TALP e da Teoria do Núcleo Central evidenciaram-se as palavras ou expressões que, agrupadas e combinadas, permitem destacar alguns aspectos macroestruturais e estruturantes dos conteúdos representacionais do corpo discente investigado, possibilitando a identificação dos elementos centrais e periféricos das representações sociais examinadas.

No núcleo da representação social dos estudantes sobre a função da escola encontrouse a incumbência de orientar e preparar para a vida, para o futuro, para o ensino superior e para o mundo do trabalho. Quanto à escola, no cerne da representação social que os estudantes formulam, encontraram-se evocações que a instituição escolar é rígida, com muitas regras desnecessárias e que geram o desinteresse.

No que tange à relação da escola com a OVP, no núcleo da estrutura da representação social, os estudantes reconheceram a necessidade da escola precisa auxiliar nesse processo de forma sistemática. Um elemento a se destacar nesta representação é que, na primeira periferia, mas com tendência à centralidade, os alunos afirmaram que a escola não auxilia e, 
contraditoriamente, ajuda no processo de OVP. Ajuda, pois, contribui no desenvolvimento de competências relativas ao trabalho. Ao passo que não ajuda, pois, as atividades relativas à questão vocacional e profissional são superficiais ou raramente ocorrem.

Quanto à percepção dos discentes sobre o processo de escolha de uma carreira ou profissão, este foi tido pelos estudantes como importante, difícil e estressante. $\mathrm{O}$ reconhecimento das representações sociais e do habitus estudantil viabilizou a análise de como se desenvolve a assimilação de temáticas vocacionais, mesmo que não institucionalizada na rede de ensino do Distrito Federal, esclarecendo e levantando as expectativas dos estudantes, e fornecendo elementos para se refletir sobre a necessidade de inclusão curricular da OVP.

Identificou-se que a abordagem psicossociológica das representações sociaispraxiologia social aplicada à essa investigação no âmbito da Educação para a Carreira permitiu explorar as particularidades do habitus que está na base da construção das representações sociais, as quais contribuem para orientar os estudantes nas decisões concernentes ao seu futuro. E isso, deve-se ressaltar, dada a potencialidade explicativa desse modelo, posto que permite apreender as dimensões cognitiva, subjetiva, afetiva, social e cultural da produção dos fenômenos representacionais.

Nesse contexto, no que concerne ao objetivo de correlacionar as representações sociais identificadas com os pressupostos básicos da Educação para a Carreira, percebeu-se que diante dos anseios e das necessidades dos estudantes, essa abordagem de OVP é pertinente para auxiliar a escola na sua função de orientar e preparar os estudantes a fim de que o trabalho seja possível, significativo e satisfatório para cada um.

O conceito ampliado de trabalho, a integração dos processos de ensino-aprendizagem e de desenvolvimento vocacional por meio do currículo, o desenvolvimento de hábitos e atitudes relativos ao trabalho e a colaboração entre a escola e a comunidade ocupacional são quatro elementos básicos que fundamentam a Educação para a Carreira e que respondem adequadamente às demandas estudantis.

Percebeu-se ao longo da investigação que, por meio da Educação para a Carreira é possível: aproximar a educação e o trabalho e com isso aumentar a motivação e o interesse em sala de aula; atender as necessidades dos diferentes estudantes que possuem anseios e projetos de vida distintos, mas que precisam de ferramentas e mecanismos para saberem transitar no mundo do trabalho que se altera com rapidez; privilegiar e destacar a atuação dos educadores, inclusive o pedagogo, como sendo um dos possíveis profissionais da educação para atuarem no programa; desenvolver competências básicas e que são importantes para a formação do 
estudantes; propiciar um desenvolvimento vocacional e profissional longitudinal no processo de escolarização.

Evidenciou-se a necessidade de se adotar estratégias que guardem maior relação com o projeto de vida dos estudantes, como forma de ampliação da permanência e do sucesso destes na escola e a fim de que estes tenham a possibilidade de construir seu projeto de vida, definindo e trilhando caminhos para a sua vida em sociedade.

Quanto ao objetivo de produção de um Relatório Técnico Conclusivo foi possível apresentar o conteúdo das iniciativas de Projeto de Vida das Secretarias de Estado de Educação viabilizando-se um panorama geral e o apontamento de fragilidades na maioria da construção dessas iniciativas: embora o processo de orientação e preparação para a construção de Projetos de Vida seja importante os sistemas de ensino só realizaram a inclusão curricular após a imposição legal; outro aspecto que ressaltou o mero cumprimento dessa imposição legal é que essa atividade está circunscrita apenas no ensino médio, conforme preconizam os dispositivos legais; o estabelecimento de parcerias público-privadas para a concepção, opção metodológica, formação dos profissionais e elaboração de materiais didáticos; ausência de uma concepção ou abordagem teórico-metodológica de trabalho sólida.

Ainda na produção técnica do Relatório se fez pertinente a apresentação das diretrizes e orientações pedagógicas elaboradas em âmbito federal para o trabalho com Projeto de Vida, que além da obrigatoriedade de inclusão dessa atividade no currículo de ensino médio, conforme a BNCC, trata-se de uma competência geral a ser desenvolvida pelos estudantes em toda a Educação Básica. Ademais, também descobriu-se que, diante das orientações, o Projeto de Vida: deve visar o desenvolvimento de habilidades cognitivas e não-cognitivas que capacitem o estudante no processo de orientação e desenvolvimento de um projeto para si; não se trata apenas da escolha de uma profissão, nem se dissocia desse processo, mas contribui para o autoconhecimento, para o conhecimento do mundo e reconhecimento das possibilidades, para o desenvolvimento de competências que habilitem os estudantes a fazerem boas escolhas em sua trajetória; deve motivar e despertar o interesse nos estudantes; deve trazer significado e preencher a formação acadêmica com valores.

Tendo em vista os resultados de toda a investigação, tendo por base o referencial teórico levantado, a realização da pesquisa empírica com a apreensão dos costumes, experiências, motivações, aspirações e outras regularidades do ser estudante deste campo social, a identificação dos significados ou sentidos elaborados e partilhados coletivamente pelos estudantes a respeito de temas vocacionais e que servem de guia para a ação deste grupo, o mapeamento das iniciativas de trabalho com Projeto de Vida nas Secretarias de Estado de 
Educação e a apresentação das diretrizes e orientações pedagógicas elaboradas em âmbito federal para o trabalho com Projeto de Vida, confirma-se a pertinência da Educação para a Carreira como uma abordagem de OVP capaz de responder adequadamente às lacunas identificadas nos processos formativos, às demandas solicitadas pelo Estado e pela sociedade e aos anseios e expectativas dos estudantes.

A Educação para a Carreira é apropriada, pois, é uma modalidade de OVP realizada no contexto escolar, construída para ser desenvolvida por professores e tem a sua base em atividades pedagógicas condizentes com a atuação docente e tem como eixo central a categoria trabalho, que preenche de sentido a formação dos estudantes. Nessa abordagem defende-se a educação pública e democrática, uma formação longitudinal que pode progredir ao longo de todo o currículo da educação básica (e não apenas na etapa final), a preparação para as transições da vida acadêmica, profissional e de outras dimensões, bem como a aptidão para a realização de escolhas mais consistentes.

Portanto, por meio da inclusão das atividades de Educação para a Carreira na educação básica é possível ampliar e transformar o entendimento e a percepção dos discentes preparandoos para o seu processo de escolha e tomada de decisões em seu Projeto de Vida. Por meio desse trabalho é possível construir e reconstruir os sentidos atribuídos à escola, aos estudos e ao trabalho.

É um grande desafio a inclusão da temática vocacional nos currículos, corre-se o risco de introduzir no ensino propostas instrumentais, utilitaristas ou que focalizem a questão da empregabilidade. Nesse sentido, cabe ressaltar que na adoção da Educação para a Carreira, enquanto teoria fundante, é possível buscar superar esse paradigma, prezando-se por uma acepção mais ampla de trabalho, situando-o como princípio educativo e como núcleo estruturador da vida em sociedade e não submetido à lógica de mercado de trabalho.

Diante desse quadro e à guisa de conclusão desta investigação, defende-se a democratização do acesso à OVP, atualmente restrita a grupos diminutos, constituindo-se em uma política pública para ser universalmente institucionalizada nos sistemas de ensino, sobretudo para o Distrito Federal, contexto desta investigação. Advoga-se por uma formação integral e crítica que possibilitem aos estudantes enfrentarem o mundo do trabalho e defenderem o seu Projeto de Vida, mas também o seu projeto social. E que, se o Estado não fizer a opção por um embasamento teórico-metodológico claro, que os professores possam, na liberdade da construção do seu trabalho pedagógico, oportunizarem aos estudantes esse direito de aprendizagem ao desenvolvimento vocacional vinculado aos processos de ensinoaprendizagem embasados nos pressupostos da Educação para a Carreira. 
Acredita-se ter atingido o objetivo proposto para este trabalho, mas reconhece-se também que diante da complexidade das representações sociais e do habitus estudantil que nem tudo que se constatou foi dito e muito mais há para ser desvelado e analisado. Espera-se que esta pesquisa suscite mais debates e instigue outros pesquisadores a evidenciarem a importância e pertinência da OVP e da Educação para a Carreira e a aplicarem o modelo teórico-metodológico em outros contextos e com outros sujeitos a fim de apreender outras realidades e representações sociais.

Espera-se que o leitor tenha sido conduzido à reflexão sobre a relevância da OVP e temse a expectativa de que os resultados elencados nesta investigação contribuam com as discussões sobre a temática com vistas à construção do Projeto de Vida dos estudantes. 


\section{REFERÊNCIAS}

ABRIC, Jean-Claude. A abordagem estrutural das representações sociais. In: MOREIRA, Antônia S. P. e OLIVEIRA, Denise C. (Orgs.). Estudos Interdisciplinares de representação social. Goiânia: AB, 1998, p. 27-38.

BARDIN, Laurence. Análise de conteúdo. Lisboa: Edições 70, 1977.

BOGDAN, Robert; BIKLEN, Sari. Investigação qualitativa em educação: uma introdução à teoria e aos métodos. Porto: Porto editora, 1994.

BOHOSLAVSKY, Rodolfo. Orientação vocacional: a estratégia clínica. 13.ed. São Paulo: Martins Fontes, 2015.

BRASIL. Lei $n^{0}$ 9.394, de 20 de dezembro de 1996. Estabelece as diretrizes e bases da educação nacional. Brasília, 1996. Disponível em: <http://www.planalto.gov.br/ccivil_03/leis/L9394.htm>. Acesso em 6 de abril de 2019.

Resolução CNE/CP no 1 , de 15 de maio de 2006. Institui Diretrizes Curriculares Nacionais para o Curso de Graduação em Pedagogia, licenciatura. Brasília, 2006. Disponível em: <http://portal.mec.gov.br/cne/arquivos/pdf/rcp01_06.pdf>. Acesso em 6 de abril de 2019.

BRASIL. Medida Provisória $\mathbf{n}^{\mathbf{0}}$ 746, de 22 de setembro de 2016. Institui a Política de Fomento à Implementação de Escolas de EMTI, altera a Lei n ${ }^{\circ}$ 9.394, de 20 de dezembro de 1996 [...]. Brasília, 2016. Disponível em: <http://www.planalto.gov.br/ccivil_03/_Ato20152018/2016/Mpv/mpv746.htm>. Acesso em 6 de abril de 2019.

Lei $\mathbf{n}^{\mathbf{0}} \mathbf{1 3 . 4 1 5}$, de 16 de fevereiro de 2017. Altera as Leis $\mathrm{n}^{\circ} 9.394$, de 20 de

dezembro de 1996 [...]. Brasília, 2017a. Disponível em: <http://www.planalto.gov.br/ccivil_03/_Ato2015-2018/2017/Lei/L13415.htm>. Acesso em 6 de abril de 2019.

Resolução CNE/CP $\mathbf{n}^{\mathbf{0}}$ 2, de 22 de dezembro de 2017. Institui e orienta a implantação da Base Nacional Comum Curricular, a ser respeitada obrigatoriamente ao longo das etapas e respectivas modalidades no âmbito da Educação Básica. Brasília, 2017b. Disponível em: <http://portal.mec.gov.br/docman/dezembro-2018-pdf/104101-rcp00418/file>. Acesso em 6 de abril de 2019.

Resolução CNE/CEB no 3, de 21 de novembro de 2018. Atualiza as Diretrizes Curriculares Nacionais para o Ensino Médio. Brasília 2018a. Disponível em: <http://www.in.gov.br/materia/-/asset_publisher/Kujrw0TZC2Mb/content/id/51281622>. Acesso em 6 de abril de 2019.

Resolução CNE/CP no 4, de 17 de dezembro de 2018. Institui a Base Nacional Comum Curricular na Etapa do Ensino Médio [...]. Brasília 2018b. Disponível em: $<$ http://portal.mec.gov.br/docman/dezembro-2018-pdf/104101-rcp004-18/file>. Acesso em 6 de abril de 2019.

CAPES. Portaria $\mathbf{n}^{\mathbf{0}}$ 60, de 20 de março de 2019. Dispõe sobre o mestrado e doutorado profissionais, no âmbito da Coordenação de Aperfeiçoamento de Pessoal de Nível Superior. Brasília, 2019a. Disponível em: 
<https://capes.gov.br/images/novo_portal/portarias/22032019_Portarias_59e60.pdf>. Acesso em 6 de abril de 2019.

MEC. Orientações para a Construção das Propostas de Flexibilização Curricular. Brasília, 2019b.

Orientação pedagógica para trabalho com Projeto de Vida enquanto componente curricular: Diretrizes para elaboração de material pedagógico. Brasília, 2019c.

CAPES. Grupo de Trabalho de Produção Técnica. Relatório Final de Atividades. Brasília, 2018.

Disponível

em: <https://sat.ufba.br/sites/sat.ufba.br/files/relatorio_gt_producao_tecnica_2018_-

_2_versao.pdf $>$. Acesso em 13 de abril de 2019.

CARNOY, Martin; LEVIN, Henry M. Escola e Trabalho no Estado capitalista. São Paulo, Cortez \& Associados, 1987.

CARVALHO, Olgamir Francisco de. Desafios atuais da escolha e decisão vocacional/profissional: um olhar pedagógico sobre a questão. Trabalho \& Educação (UFMG), v. 23, p. 93-107, 2014. Disponível em: <https://periodicos.ufmg.br/index.php/trabedu/article/view/9280/6664>. Acesso em: 04 de novembro de 2017.

Editora, 2003.

Educação e formação profissional - trabalho e tempo livre. Brasília: Plano

CODEPLAN. Pesquisa Distrital por Amostra de Domicílios - Taguatinga PDAD 2016. Disponível em: <http://www.codeplan.df.gov.br/wp-content/uploads/2018/02/PDADTaguatinga-1.pdf $>$. Acesso em 12 de janeiro de 2019.

CONSED. Novo Ensino Médio. 2016. 12 slides.

DE MASI, Domenico. $\mathbf{O}$ futuro do trabalho: fadiga e ócio na sociedade pós-industrial. Trad. de Yadyr A. Figueiredo. Rio de Janeiro: José Olympio; Brasília, DF: Editora da UnB, 1999.

DISTRITO FEDERAL. SEEDF. SUBEB. COEJA. DIEM. Ensino Médio em Debate Fascículo n 3 - Projeto de Vida: um olhar para o estudante. Brasília, 2018.

Portaria no 173, de 20 de junho de 2018. Dispõe sobre critérios para concessão de aptidão para os servidores integrantes da Carreira Magistério Público do Distrito Federal. Brasília, 2018b. Disponível em: <http://www.tc.df.gov.br/sinj/Norma/3d4887bde48245639afcc6e9b5dee944/Portaria_173_20 _06_2018.html>. Acesso em 28 de maio de 2019.

Portaria $\mathbf{n}^{0}$ 171, de 21 de maio de 2019. Institui Grupo de Trabalho com o objetivo de elaborar as diretrizes pedagógicas para o desenvolvimento do componente curricular Projeto de Vida [...]. Brasília, 2019. Disponível em: http://www.se.df.gov.br/wpconteudo/uploads/2019/05/portaria-171-de-21-maiio-2019.pdf. Acesso em 28 de maio de 2019.

DOMINGOS SOBRINHO, Moisés. Representações sociais e praxiologia bourdieusiana: notas sobre a aplicação de um modelo a fenômenos do campo educacional. In: LIRA, A. A. D. (Org.); 
MIRANDA, M. M. (Org.); BRITO, S. M. de O. (Org.). Revisitando o diálogo em representações sociais e educação. 1ed.Campina Grande: EDUFCG, 2014, v. 01, p. 23-56.

Habitus e representações sociais: questões para o estudo de identidades coletivas. In: MOREIRA, Antonia Silva Paredes; OLIVEIRA, Denise Cristina de (Orgs.). Estudos interdisciplinares de representação social. 2. ed. Goiânia: AB, 2000. p. 117-130.

Classe média assalariada e representações sociais da Educação: algumas questões de ordem teórico-metodológicas. In: MADEIRA, Margot Campos (Org.). Representações sociais e educação: algumas reflexões. Natal: EDUFRN, 1998. p. 21-38.

EHRLICH, I. F.; CASTRO, F.; SOARES, D. H. P. Orientação Profissional: liberdade e determinantes da escolha profissional. Revista de Ciências Humanas, Florianópolis: EDUFSC, n. 28, p. 61-79, out. 2000. Disponível em: <https://periodicos.ufsc.br/index.php/revistacfh/article/viewFile/24001/21477>. Acesso em: 04 de novembro de 2017.

FERRETTI, João Celso. Uma nova proposta de orientação profissional. $2^{\mathrm{a}}$. Ed. São Paulo: Cortez, 1992.

GAMBOA, Sílvio A. Sanchez. A dialética na pesquisa em educação: elementos de contexto. In: FAZENDA, Ivani (Org.). Metodologia da pesquisa educacional. 11. ed. São Paulo: Cortez, 2008.

GUICHARD, Jean; HUTEAU, Michel. Psicologia da orientação. Lisboa: Instituto Piaget, 2002.

GREENHAUS, J. H.; CALLANAN, G. A. Encyclopedia of carrer development. Thousand Oaks, CA: Sage, 2006.

GRUPO de Desenvolvimento Integral do Movimento pela Base e o Center for Curriculum Redesign. Dimensões e Desenvolvimento das Competências Gerais da BNCC. 2018. 73 slides.

HOYT, Kenneth B. An introduction to Career Education. A Policy Paper of the U.S. Office of Education. Washington, DC: U.S. Government Printing Office. 1975.

Career education: History and future. Oklahoma: National Career Development Association, 2005.

INSTITUTO NACIONAL DE ESTUDOS E PESQUISAS EDUCACIONAIS ANÍSIO TEIXEIRA. Estatísticas da Educação Superior. Brasília: Inep, 2018. Disponível em: $<$ http://portal.inep.gov.br/web/guest/sinopses-estatisticas-da-educacao-superior >. Acesso em: 05 de dezembro de 2018.

IRVING, Barrie A. (Re)constructing career education as a socially just practice: An antipodean reflection. International Journal for Educational and Vocational Guidance. Springer, 2010., vol. 10, n. 1, p. 49-63. Disponível em: <https://link.springer.com/article/10.1007\%2Fs10775-009-9172-1>. Acesso em: 02 de fevereiro de 2019. 
LEVENFUS, Rosane Schotgues. Geração Zapping e o Sujeito da Orientação Vocacional. In: LEVENFUS, Rosane Schotgues; SOARES, Dulce Helena Penna. (Orgs) Orientação Vocacional Ocupacional. Porto Alegre: Artmed, 2002, p. 33-50.

MOSCOVICI, Serge. A representação social da psicanálise. Rio de Janeiro: Zahar, 1978.

Vozes, 2009.

Representações Sociais: investigações em psicologia social. 6 ed. Petrópolis, RJ:

MUNHOZ, Izildinha Maria Silva; MELO-SILVA, Lucy Leal. Educação para a Carreira: concepções, desenvolvimento e possibilidades no contexto brasileiro. Rev. bras. orientac. prof [online]. 2011, vol.12, n.1, p. 37-48. Disponível em: <http://pepsic.bvsalud.org/scielo.php?script=sci_arttext\&pid=S1679-33902011000100006>. Acesso em: 04 de novembro de 2017.

; AUDIBERT, Alyane. Educação para a carreira: pistas para intervenções na educação básica. In: LEVENFUS, Rosane Schotgues (Org.). Orientação vocacional e de carreira em contextos clínicos e educativos. Porto Alegre: Artmed, 2016.

OLIVEIRA, D.C; MARQUES, S.C.; GOMES, A.M.T.; TEIXEIRA, M.A.T.V. Análise das evocações livres: uma técnica de análise estrutural das representações sociais. In: MOREIRA, Antonia Silva Paredes et al. (Orgs.). Perspectivas teórico-metodológicas em representações sociais. João Pessoa: Editora Universitária, 2005. p. 573-603.

ORGANISATION FOR ECONOMIC COOPERATION AND DEVELOPMENT (OECD). Career guidance and public policy - bridging the gap. Paris: OECD, 2004. Disponível em: <http://www.oecd.org/education/innovation-education/34050171.pdf >. Acesso em: 04 de novembro de 2017.

PERONI, Vera Maria Vidal. A gestão democrática da educação em tempos de parceria entre o público e o privado. Pro-Posições [online]. 2012, vol.23, n.2, pp.19-31. Disponível em: <http://dx.doi.org/10.1590/S0103-73072012000200003>. Acesso em: 06 de novembro de 2017.

PERRENOUD, Philippe. Desenvolver competências ou ensinar saberes? A Escola que prepara para a vida. Porto Alegre: Penso, 2013.

RODRÍGUEZ MORENO, Maria Luísa. A educação para a carreira: aplicações à infância e à adolescência. In: TAVEIRA, M. C.; SILVA; J. T. (Orgs.) Psicologia Vocacional: perspectivas para intervenção. Coimbra: Imprensa da Universidade de Coimbra. p. 25-54, 2008.

RODRÍGUEZ, Soledad Romero; CARMONA, Teresa Padilla. Historia del movimiento de educación para la carrera. In: RODRÍGUEZ, Maria Luísa (Coord.). Educación para la carrera y diseño curricular: Teoría y práctica de programas de educación para el trabajo, Barcelona: U. B. p. 41-76, 1995.

SANT'ANNA, H.C. OpenEvoc: Um programa de apoio à pesquisa em representações sociais. Revista Psicologia Social: Desafios Contemporâneos. Espírito Santo: 2012. p. 94-103.

SARTRE, Jean-Paul. O existencialismo é um humanismo. Trad. de Rita Correia Guedes. Coleção Os Pensadores. São Paulo: Nova Cultural, 1987. 
SAVIANI, Demerval. O trabalho como princípio educativo frente às novas tecnologias. In: FERRETTI, Celso João et al (Org.) Novas tecnologias, trabalho e educação: um debate multidisciplinar. Petrópolis: Vozes, 2010. p.151-168.

ZAGO, Nadir. Do acesso à permanência no ensino superior: percursos de estudantes universitários de camadas populares. Rev. Bras. Educ., Rio de Janeiro, 2006, v.11, n. 32, p. 226-237. Disponível em: <http://www.scielo.br/pdf/rbedu/v11n32/a03v11n32.pdf>. Acesso em: 06 de novembro de 2017. 


\title{
APÊNDICE A - TERMO DE CONSENTIMENTO LIVRE E ESCLARECIDO E TESTE DE ASSOCIAÇÃO LIVRE DE PALAVRAS
}

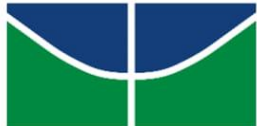 \\ UNIVERSIDADE DE BRASÍLIA - UnB / FACULDADE DE EDUCAÇÃO - FE \\ PROGRAMA DE PÓS-GRADUAÇÃO EM EDUCAÇÃO MODALIDADE PROFISSIONAL - PPGE-MP
}

\section{TERMO DE CONSENTIMENTO LIVRE E ESCLARECIDO}

Prezado(a) estudante,

Meu nome é Klever Corrente Silva e sou mestrando do Programa de Pós-graduação em Educação modalidade profissional, da Faculdade de Educação da Universidade de Brasília (FE/UnB). Estou realizando uma pesquisa sobre Orientação Vocacional e Profissional sob a orientação da professora Dra. Olgamir Francisco de Carvalho.

Gostaríamos de convidá-lo(a) a colaborar de forma voluntária com esta pesquisa. Para isso, utilizaremos dois instrumentos: um Teste de Associação Livre de Palavras que consiste no preenchimento de frases incompletas com palavras ou expressões curtas e também na justificativa do preenchimento e um Questionário com temáticas específicas sobre o assunto em tela.

Se decidir não participar ou quiser desistir de continuar em qualquer momento, tem absoluta liberdade de fazê-lo. Os resultados desta pesquisa serão publicados, mas sua privacidade será respeitada, pois sua identidade e dados pessoais prestados serão mantidos em sigilo.

Portanto, tendo sido orientado(a) quanto ao teor aqui mencionado e compreendido a natureza e o objetivo do referido estudo, manifeste seu livre consentimento em participar, assinalando com o campo abaixo.

$\square$ Concordo em participar voluntariamente do estudo 


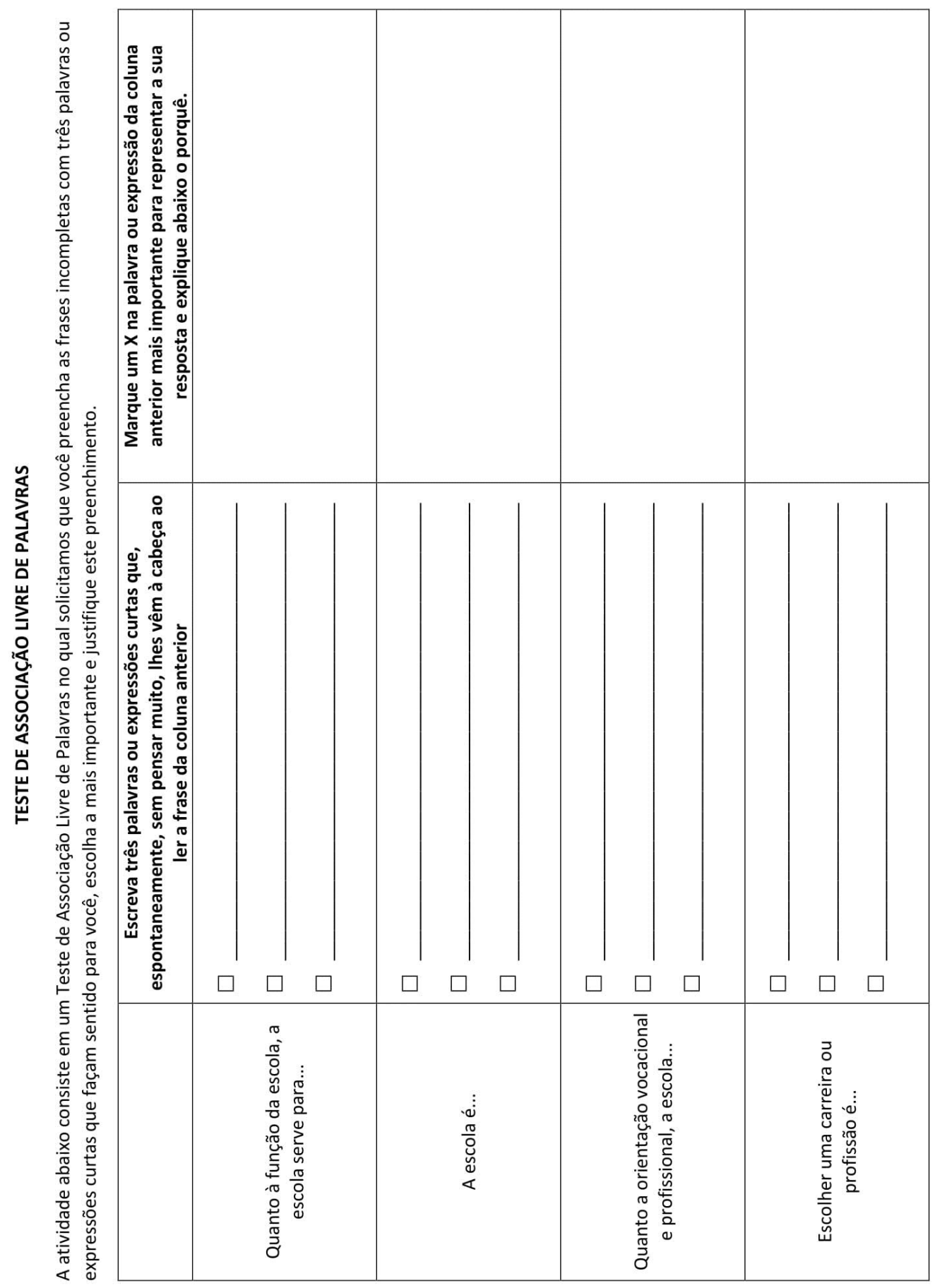

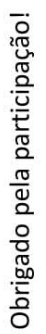


APÊNDICE B - QUESTIONÁRIO SOCIOECONÔMICO E CULTURAL

\title{
Pesquisa: Orientação Vocacional e Profissional
}

\author{
TERMO DE CONSENTIMENTO LIVRE E ESCLARECIDO
}

Prezado(a) estudante,

Meu nome é Klever Corrente Silva e sou mestrando do Programa de Pós-graduação em Educação modalidade profissional, da Faculdade de Educação da Universidade de Brasília (FE/UnB). Estou realizando uma pesquisa sobre Orientação Vocacional e Profissional sob a orientação da Professora Dra. Olgamir Francisco de Carvalho.

Gostaríamos de convidá-lo(a) a colaborar de forma voluntária com esta pesquisa. Para isso, utilizaremos dois instrumentos: um Teste de Associação Livre de Palavras que consiste no preenchimento de frases incompletas com palavras ou expressões curtas e também na justificativa do preenchimento e um Questionário com temáticas específicas sobre o assunto em tela.

Se decidir não participar ou quiser desistir de continuar em qualquer momento, tem absoluta liberdade de fazê-lo. Os resultados desta pesquisa serão publicados, mas sua privacidade será respeitada, pois sua identidade e dados pessoais prestados serão mantidos em sigilo.

Portanto, tendo sido orientado(a) quanto ao teor aqui mencionado e compreendido a natureza e o objetivo do referido estudo, manifeste seu livre consentimento em participar, assinalando com o campo abaixo.

*Obrigatório

*

Concordo em participar voluntariamente do estudo

PRÓXIMA

Nunca envie senhas pelo Formulários Google. 


\section{Pesquisa: Orientação Vocacional e Profissional}

*Obrigatório

\section{QUESTIONÁRIO}

1. Idade *

16 anos ou menos

17 anos

18 anos

19 anos ou mais

2. Sexo *

Masculino

Feminino

3. Em que tipo de estabelecimento você cursou a educação básica (educação infantil, ensino fundamental e ensino médio)? *

Toda em escola pública

Maior parte em escola pública

Maior parte em escola particular sem bolsa

Maior parte em escola particular com bolsa 
4. Qual é a escolaridade do seu pai? *

Não alfabetizado

Ensino fundamental incompleto

Ensino fundamental completo

Ensino médio incompleto

Ensino médio completo

Graduação incompleta

Graduação completa

Pós-graduação incompleta

Pós-graduação completa

5. Qual é a profissão/ocupação do seu pai? (Se está desempregado, informar). *

\section{Sua resposta}

6. Qual é a escolaridade da sua mãe? *

Não alfabetizada

Ensino fundamental incompleto

Ensino fundamental completo

Ensino médio incompleto

Ensino médio completo

Graduação incompleta

Graduação completa

Pós-graduação incompleta

Pós-graduação completa

7. Qual é a profissão/ocupação da sua mãe? (Se está desempregada, informar). * 
8. Com que frequência os seus familiares costumam conversar com você sobre carreiras ou profissões? *

Nunca

Raramente

Às vezes

Frequentemente

9. Com que frequência os seus colegas costumam conversar com você sobre carreiras ou profissões? *

$\bigcirc$ Nunca

Raramente

Às vezes

Frequentemente

10. Com que frequência a escola costuma realizar atividades e conversar com você sobre carreiras ou profissões? *

Nunca

Raramente

Às vezes

Frequentemente

11. Com que frequência você costuma pesquisar ou ler sobre carreiras ou profissões? *

Nunca

Raramente

Às vezes

Frequentemente 
12. ENUMERE por ordem de importância os setores, instituições, pessoas que influenciam a sua orientação vocacional e profissional. *

$\begin{array}{llllll} & 1^{\circ} & 2^{\circ} & 3^{\circ} & 4^{\circ} & 5^{\circ} \\ \begin{array}{l}\text { Pesquisa ou } \\ \text { leitura } \\ \text { individual }\end{array} & \bigcirc & \bigcirc & \bigcirc & \bigcirc & \bigcirc \\ \text { Escola } & \bigcirc & \bigcirc & \bigcirc & \bigcirc & \bigcirc \\ \text { Colegas } & \bigcirc & \bigcirc & \bigcirc & \bigcirc & \bigcirc \\ \text { Midia } & \bigcirc & \bigcirc & \bigcirc & \bigcirc & \bigcirc \\ \text { Familiares } & \bigcirc & \bigcirc & \bigcirc & \bigcirc & \bigcirc\end{array}$

13. ENUMERE por ordem de importância os fatores que você considera que mais influenciarão você no momento da escolha de uma profissão/carreira? *

\begin{tabular}{|c|c|c|c|c|c|}
\hline & $1^{\circ}$ & $2^{\circ}$ & $3^{\circ}$ & $4^{\circ}$ & $5^{\circ}$ \\
\hline $\begin{array}{l}\text { Perspectivas de } \\
\text { ganho financeiro }\end{array}$ & 0 & $\bigcirc$ & 0 & $\bigcirc$ & $\bigcirc$ \\
\hline $\begin{array}{l}\text { Status/valorização } \\
\text { social }\end{array}$ & 0 & $\bigcirc$ & $\bigcirc$ & $\bigcirc$ & $\bigcirc$ \\
\hline Vocação & 0 & 0 & $\bigcirc$ & 0 & $\mathrm{O}$ \\
\hline $\begin{array}{l}\text { Oportunidades do } \\
\text { mercado de } \\
\text { trabalho }\end{array}$ & O & $\bigcirc$ & $\bigcirc$ & $\bigcirc$ & 0 \\
\hline $\begin{array}{l}\text { Possibilidade de } \\
\text { autorrealização } \\
\text { atraveves do trabalho }\end{array}$ & $\mathrm{O}$ & $\bigcirc$ & O & $\bigcirc$ & ) \\
\hline $\begin{array}{l}\text { Obrigação de } \\
\text { escolher }\end{array}$ & 0 & 0 & 0 & $\bigcirc$ & O \\
\hline
\end{tabular}

14. Já fez ou faz algum curso ou formação que prepare para alguma atividade ocupacional ou profissional? *

Não

$\operatorname{sim}$

15. Quais? *

Não se aplica, pois não fiz/faço curso ou formação

Outro: 
16. Por qual motivo fez ou faz esse(s) curso(s) ou formação(ões)? *

Não se aplica, pois não fiz/faço curso ou formação

Outro:

17. Se já fez ou faz algum curso ou formação, ele tem alguma relação com as escolhas que você pretende fazer? *

$\operatorname{sim}$

Não

Não se aplica, pois não fiz/faço curso ou formação

18. Já exerceu ou exerce algum tipo de trabalho remunerado? *

Sim

Não

19. Se já exerceu ou exerce algum tipo de trabalho remunerado, ele tem alguma relação com as escolhas que você pretende fazer? *

$\operatorname{sim}$

Não

Não se aplica, pois não exerci/exerço trabalho remunerado

20. Qual é a sua primeira aspiração para quando concluir o ensino médio? *

Ter o seu próprio negócio

Estudar e buscar a aprovação em um concurso público

Fazer um curso técnico

Inserir-se no mercado de trabalho

Fazer um curso superior

Outro: 
21. Ao longo da educação básica (educação infantil, ensino fundamental e ensino médio) você vivenciou na escola atividades que o preparem para o processo de escolha da carreira/profissão? *
Nenhuma
Poucas
Algumas
Muitas

22. Se vivenciou na escola atividades que o preparem para o processo de escolha de carreira/profissão, informe quais: *
Não vivenciei atividades dessa natureza
Outro:

23. Ao longo da educação básica (educação infantil, ensino fundamental e ensino médio) você realizou visita técnica ou alguma atividade em alguma universidade ou faculdade? *
Não
Sim, em uma instituição pública
Sim, em uma instituição privada
Sim, em instituições pública(s) e privada(s)

24. Se, pela escola, realizou visita técnica ou alguma atividade em alguma universidade ou faculdade, explique como foi promovida/realizada. *

Não vivenciei atividades dessa natureza

Outro: 


\section{Pesquisa: Orientação Vocacional e Profissional}

Sua resposta foi registrada.

Obrigado pela participação, você contribuiu para a compreensão do assunto estudado, para a produção de conhecimento científico e para a reflexão de melhoria do serviço aos alunos. 